\title{
45. SEDIMENT SYNTHESIS: DEEP SEA DRILLING PROJECT LEG 58, PHILIPPINE SEA
}

\author{
Stan M. White, ${ }^{1}$ Hervé Chamley, ${ }^{2}$ Doris Curtis, ${ }^{3}$ George deVries Klein, ${ }^{4}$ and Atsuyuki Mizuno, ${ }^{5}$ with a special \\ contribution on physical properties by David M. Fountain ${ }^{6}$
}

\section{INTRODUCTION}

Five sites were drilled on DSDP. Leg 58 in the north Philippine Sea (Figure 1). The total penetration was 2971.5 meters, with 1591.8 meters recovered $(54 \%)$. One re-entry operation was completed (Site 442).

Primary objectives of Leg 58 (see also introductory chapter in this volume) were to examine the geologic history of the north Philippine Sea and to test two models for the origin of back-arc basins. Those two models are: (1) origin of marginal basins by a rifting process identical to sea-floor spreading, and (2) origin of marginal basins by entrapment of older oceanic crust behind a younger active trench. Three sites were drilled in the Shikoku Basin, where surveys suggested a symmetrical arrangement of magnetic anomalies, to test the spreading model, and two sites were drilled in the Daito Ridge and Basin province to test the entrapment model.

Leg 58 provided an opportunity to answer several questions relevant to the problems of the sedimentology of back-arc basins in the western Pacific. These problems include (1) an analysis of the variability of sediment styles and processes in each of the basins; (2) the causes of sediment variability; (3) the effect of paleocirculation on sedimentation in the basins; and (4) the relationship of sediment facies to tectonic evolution in such back-arc basins.

The purpose of this chapter is to synthesize the sedimentology of the north Philippine Sea. ${ }^{7}$ Our synthesis is based on sedimentological studies from Leg 58 sediment cores and focuses on specific problems posed by drilling during Leg 58.

\footnotetext{
${ }^{1}$ Deep Sea Drilling Project, Scripps Institution of Oceanography, La Jolla, California. Present address: Robertson Research (U. S.) Inc., Houston, Texas.

${ }^{2}$ Sedimentologie et Géochimie, Université des Sciences et Techniques de Lille, U.E.R. des Sciences de la Terre, Villeneuve d'Ascq, France.

${ }^{3}$ Shell Development Company, Bellaire Research Center, Houston, Texas. Present address: 16730 Hedgecroft, Suite 306, Houston, Texas.

${ }^{4}$ University of Illinois/Urbana-Champaign, Department of Geology, Urbana, Illinois.

${ }_{5}$ Geological Survey of Japan, Kawasaki, Japan

${ }^{6}$ University of Montana, Department of Geology, Missoula, Montana.

${ }^{7}$ With contributions by Dorothy Echols, Hisatake Okada and Jon Sloan (paleontology); Douglas Waples (organic geochemistry); and Hajimu Kinoshita (paleomagnetism).
}

\section{SOURCES OF DATA}

Major sources of data are analyses and interpretations of the visual core descriptions and smear-slide data prepared during the cruise and information derived from post-cruise studies. DSDP laboratories at Scripps Institution of Oceanography provided grain-size, organic-carbon, and calcium-carbonate data (see White, this volume).

The introduction to this volume discusses background and objectives of the Leg 58 drilling program and contains explanatory notes relating to core-handling and sediment conventions, as well as specific data on age determinations. The reader is also referred to the site-summary chapters in this volume, as well as to special chapters on selected sediment studies, for detailed information on the drilling sites and material contained in this synthesis.

\section{GEOLOGIC SETTING, SITE OBJECTIVES, AND STRATIGRAPHY}

\section{Shikoku Basin}

The Shikoku Basin (Figure 1) is an elongate, troughshaped marginal basin; its axis is oriented approximately north-northwest to south-southeast. A previous (preLeg 58) seismic study of the basin indicated that it has a rough acoustic-basement topography mantled by three clastic wedges (Karig, Ingle, et al., 1975; Marauchi and Asanuma, 1974, 1977).

The objectives of drilling in the Shikoku Basin (see also site reports, this volume) included (1) a test of the validity of a symmetrical-spreading model developed from mapping of magnetic anomalies (Tomoda et al., 1975; Kobayashi and Isezaki, 1976; Watts and Weissel, 1975); (2) determination of the petrology of basement rocks from this back-arc basin; (3) the study of paleomagnetic nature and history of the basin and determination of the source of the magnetic anomaly signal; and (4) a determination of the sediment distribution and sedimentation patterns and, where possible, the nature of paleocirculation in the basin.

\section{Site $\mathbf{4 4 2}$}

Site 442 is on the west side of an extinct spreading center, on magnetic anomaly 6 (19-21 m.y.), where the anomaly has strong intensity. A total of 286 meters of sediment and 160 meters of basalt were penetrated. A 


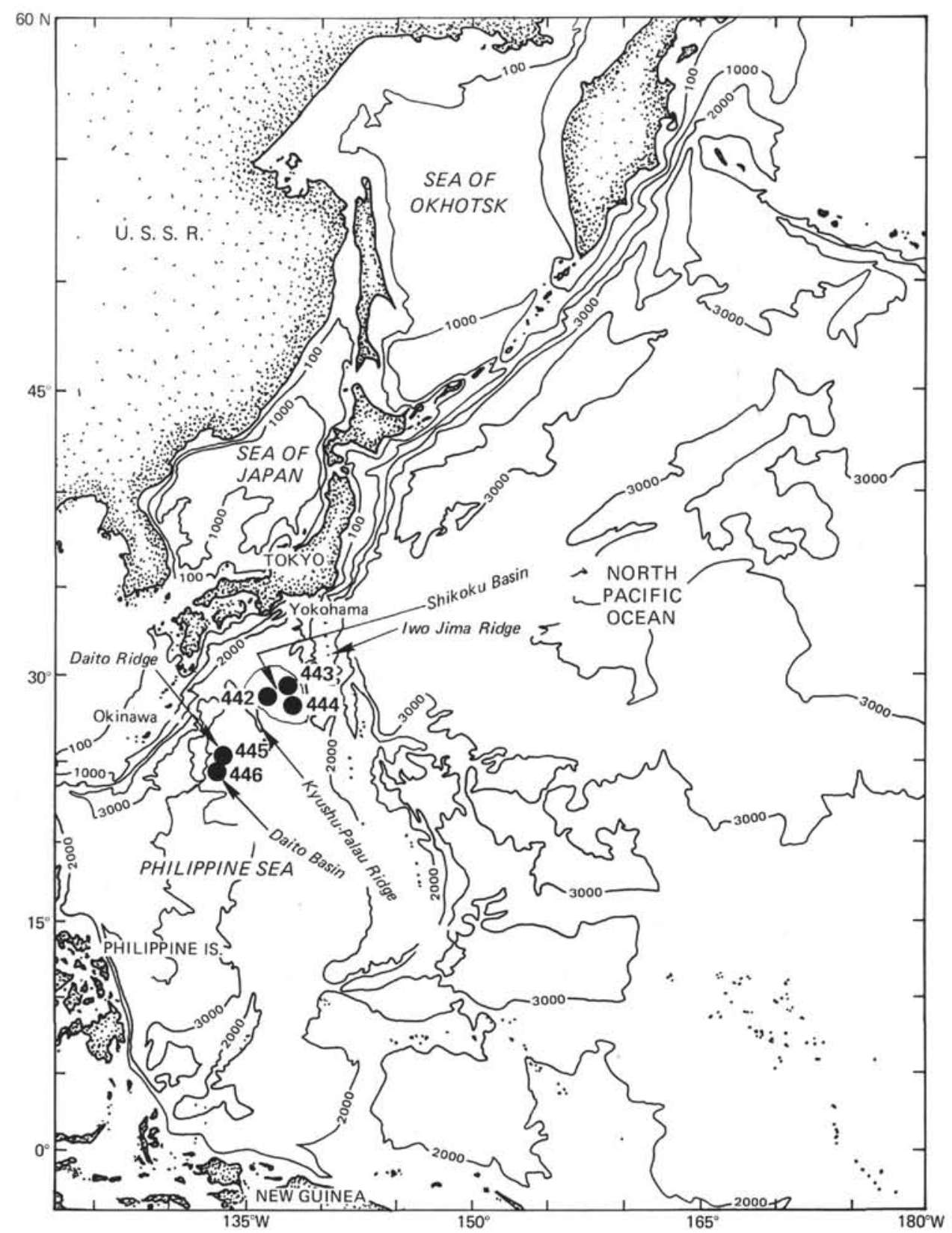

Figure 1. Location of sites drilled during Leg 58.

complete sedimentary section was recovered at Hole $442 \mathrm{~A}$, whereas at Hole $442 \mathrm{~B}$, offset 70 meters to the north of Hole $442 \mathrm{~A}$, sediments were recovered which are equivalent to the sediment units in Hole $442 \mathrm{~A}$ between 267.5 meters sub-bottom and the top of basaltic unit 1 (286.1 m sub-bottom).

The stratigraphic section consists of five lithologic units of Quaternary to early-Miocene age (Figure 2). The lowermost sedimentary unit, unit V, a 0.4-meter, pink-gray limestone, directly overlies basaltic unit 1 (see Dick et al., this volume).

The following are some significant characteristics of the sediment section drilled:

1. The sampled section is a continuous representation of the early Miocene ( $16-19$ m.y.) to the late
Quaternary and is dominated by muds and(or) clays with a tendency toward coarser sediments in Cores 442A-1 through 442A-4. Sediments of units I to III are hemipelagic, whereas sediments of unit IV are pelagic. The latter are characterized by micronodules and evidence of bioturbation.

Explosive volcanic activity which occurred near the site is evident throughout the sediment sequence: volcanic glass and pumice are irregularly disseminated in all sediments.

2. The entire sediment sequence above unit $\mathbf{V}$ is characterized by the rarity of calcium carbonate; however, nannofossils are common to abundant in Cores 442A-1 to $441 \mathrm{~A}-4$. The remainder of the section below Core 4 is virtually barren of calcareous microfossils, except for 
the limestone of unit $\mathrm{V}$, which contains smaller-foraminifer tests. Therefore, the depositional surface was either slightly above or slightly below the carbonatecompensation depth (CCD). Deposition during early and early middle Miocene occurred above the CCD, but apparently below the lysocline. From the late middle Miocene through the early Pliocene, deposition occurred below the CCD, while during the late Pliocene and Quaternary deposition occurred slightly above the CCD. The exact depth of deposition cannot be determined exactly, because no data exist concerning present or past elevations of the CCD in the Shikoku Basin (see Site 442 report, this volume).

3. Sedimentation rates range from 0.8 to $17.5 \mathrm{~m} /$ $\mathrm{m} . \mathrm{y}$. for the Miocene through the Pliocene (units V through II), increasing to $30.9 \mathrm{~m} / \mathrm{m}$.y. for the Pleistocene. ${ }^{8}$ (See Site 442 report, this volume, and section on sedimentation rates in this paper.)

4. Hemipelagic clays and claystones of units I, II, and III were deposited in a distal or basinal facies. The Kyushu-Palau Ridge appears to be the most likely source area, inasmuch as the site is on the eastern edge of a clastic wedge which thickens westward against the Kyushu-Palau Ridge, but this is not proved.

\section{Site $\mathbf{4 4 3}$}

Site 443 is on the east side of a supposed extinct spreading center, on magnetic anomaly 6A (21-22 m.y.), where the anomaly has moderate intensity. At this site, 457 meters of sediment and 125 meters of basalt were penetrated.

Five sedimentary units were distinguished, from late Pleistocene to early or middle Miocene (Figure 3, back pocket, this volume). Unit V (358.5-457.0 m), a darkgreen-gray sequence of interbedded claystone, mudstone, ash, and nannofossil chalk, is the oldest sediment recovered (15 m.y.), suggesting a basement age at variance with the age of magnetic anomaly $6 \mathrm{~A}$.

Below unit $\mathrm{V}$, the basaltic rocks includes pillow basalts, produced by crust generation at a spreading center, and intrusive basalt sills formed by off-ridge volcanism.

Significant characteristics of the sedimentary sequence are:

1. The sediment section represents a probably continuous sequence from the early or middle Miocene (about 15 m.y.) to the late Pleistocene and Holocene and is dominated by mud and mudstone. Clay minerals are the main components, throughout associated with minor quantities of quartz, feldspars, and volcanic glass. (See Chamley, this volume.)

The sediments are chiefly hemipelagic, terrigenous components being abundant throughout the section and mixed in variable proportions with planktonic components. Sediments deposited after the formation of the basin (unit V) show evidence of strong current activity, possibly indicating moderate and temporary turbidite

\footnotetext{
${ }^{8}$ Assuming the Pliocene/Pleistocene boundary at $1.6 \mathrm{~m} . \mathrm{y}$.
}

deposition. Explosive volcanic activity near the drill site is apparent from the well-defined ash layers throughout. Major volcanic activity occurred during the early middle Miocene (when sedimentation began), the early late Miocene, and the middle to late Pleistocene.

2. Calcareous and siliceous fossils occur throughout the sedimentary sequence; however, there are wide variations in the amounts of nannofossils and foraminifers, indicating changes in the CCD. This suggests that the depositional surface was above or near the CCD and probably below the lysocline.

3. Sedimentation rates were high during the early middle Miocene and the Pleistocene.

\section{Site 444}

Site 444 is on the east side of a supposed extinct spreading center, on magnetic anomaly $6 \mathrm{~A}$ (21-22 m.y.) where the anomaly has moderate intensity. A single-bit hole penetrated 272.7 meters of sediment and 37.3 meters of basalt.

The sedimentary succession consists of five lithologic units, which range in age from early or middle Miocene to Quaternary. The two basalt units are diabase sills, one of which intrudes middle-Miocene mudstones (Figure 4).

The lowest sedimentary unit, unit V (272.0-272.7 meters), a reddish-brown and greenish-gray, zeolitic, calcareous claystone (middle Miocene), overlies basalt unit 2 , a plagioclase phyric basalt and diabase. The age of this sediment is 14 to $15 \mathrm{~m}$.y., whereas the age of intrusion of the basalt sill of unit 1 is $14.7 \pm 2.1 \mathrm{~m}$.y. (see McKee and Klock, this volume). Both basalt units appear to be younger than the initial sedimentation and probably indicate an episode of off-ridge volcanism in the Shikoku Basin that post-dates the youngest age of spreading, reported as 17 m.y. by Kobayashi and Isezaki (1976) and Kobayashi and Nakada (1977).

Significant aspects of the sediments at Site 444 are as follows:

1. In general, the sediments are predominantly hemipelagic mud, with abundant volcanic glass and large proportions of terrigenous clay and silt. The pyroclastics occur either as discrete layers, or as components of the mudstone. Hard, well-lithified mudstone and claystone occur in several cores above and between basalts. Pelagic, zeolitic nannofossil claystone or ooze is present in the lowest meter of sediment above the second basalt layer.

2. Volcanic activity was intense in the site vicinity during deposition of most of the sedimentary sequence; it was less intense during the late Miocene and Pleistocene than at other times. Variations in nearby volcanic activity are reflected also in distribution and thickness of ash beds, which show graded, upward-fining bedding. Where the ash is a relatively pure glass associated with nannofossil mud, it represents settling of ash from suspension in the absence of currents, rather than turbidity-current deposition. In these cases, the ash content decreases upward as the nannofossil content increases.

3. Calcareous nannofossils are present in varying quantities in most of the section. Siliceous microfossils 


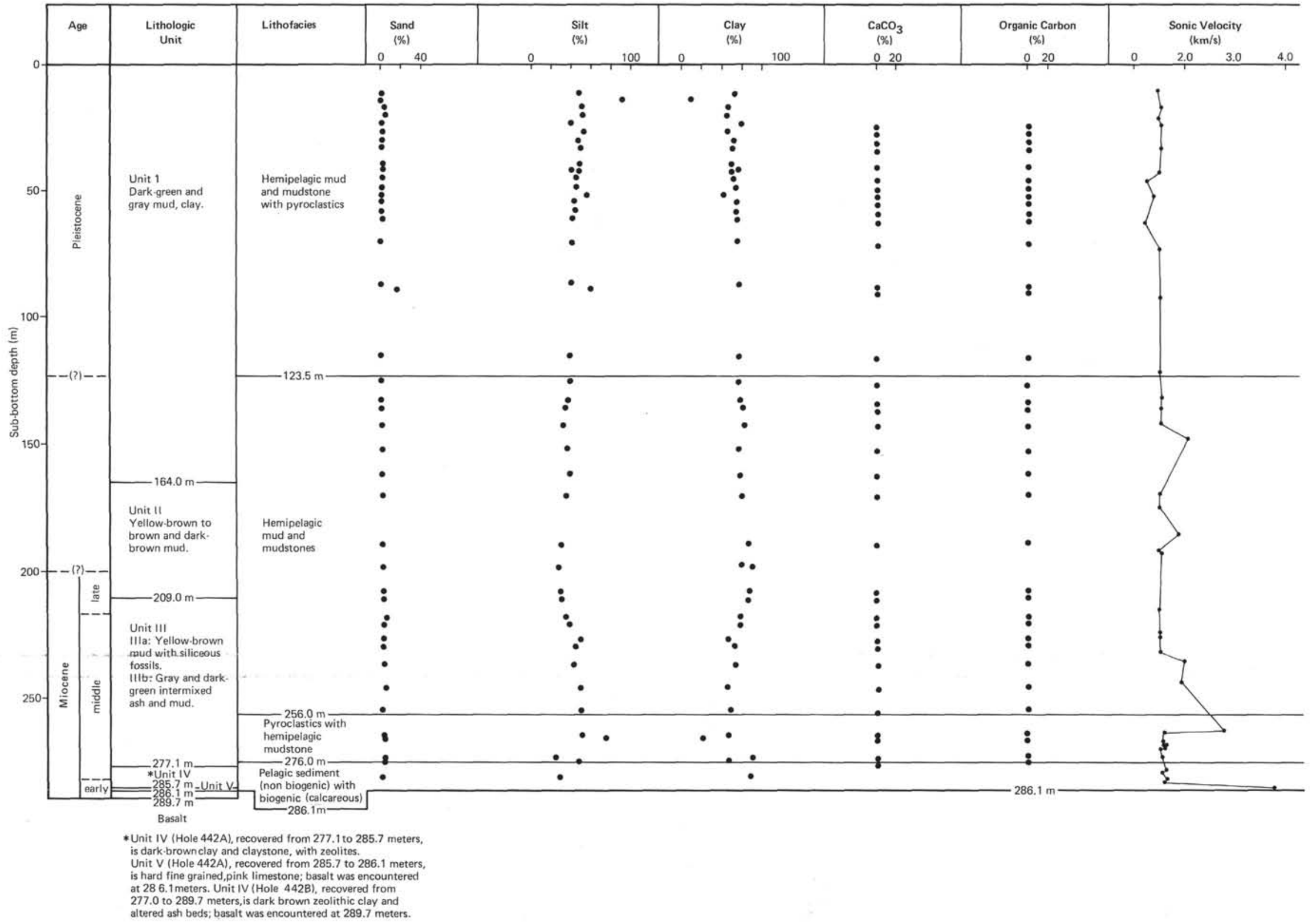

Figure 2. Stratigraphy, lithofacies, and sediment data, Site 442. 


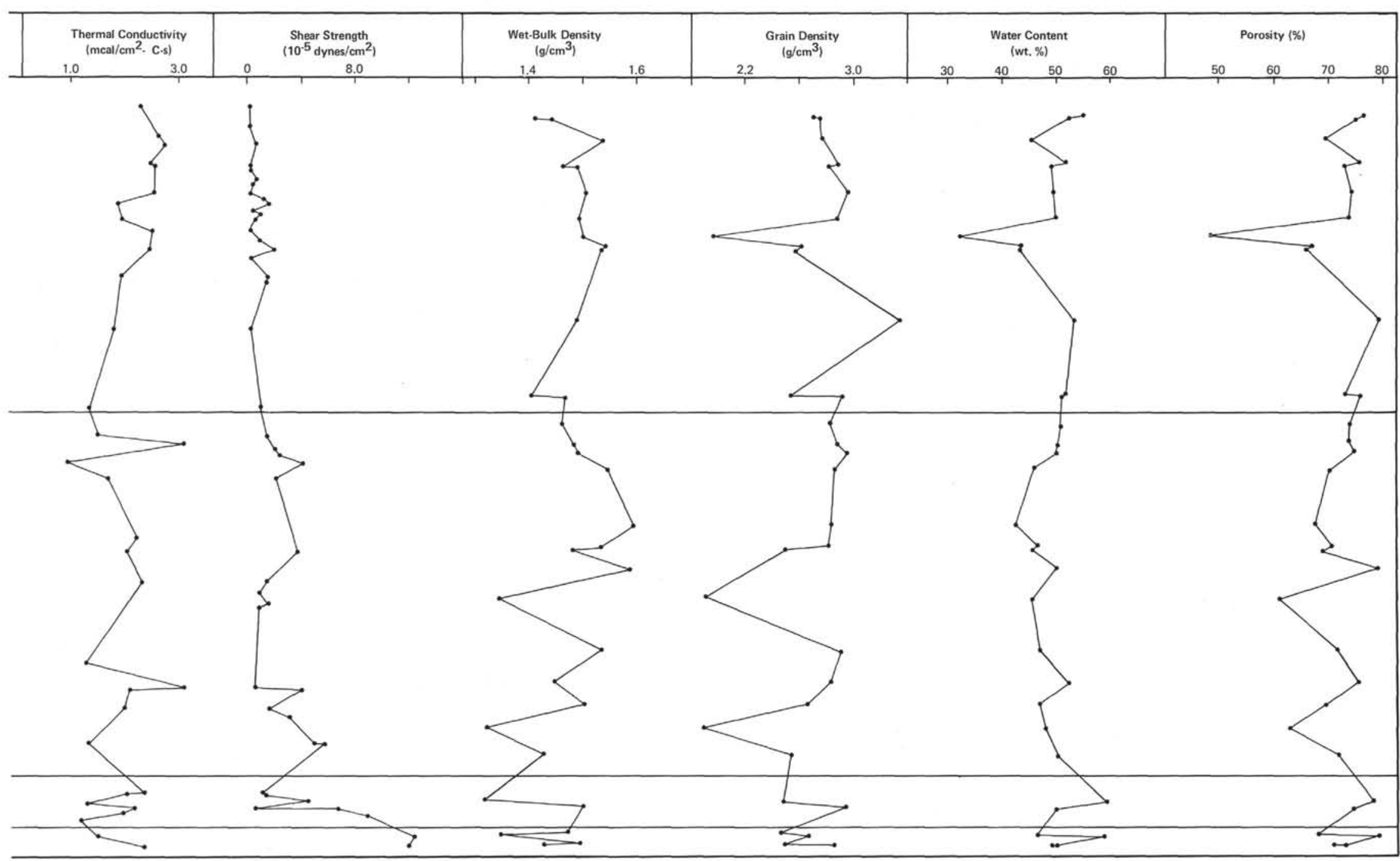

Figure 2. (Continued). 
Site: 444

Water depth: $4843 \mathrm{~m}$. Total penetration: 91.5 (Hole 444), $310.0 \mathrm{~m}$ (Hole 444A).

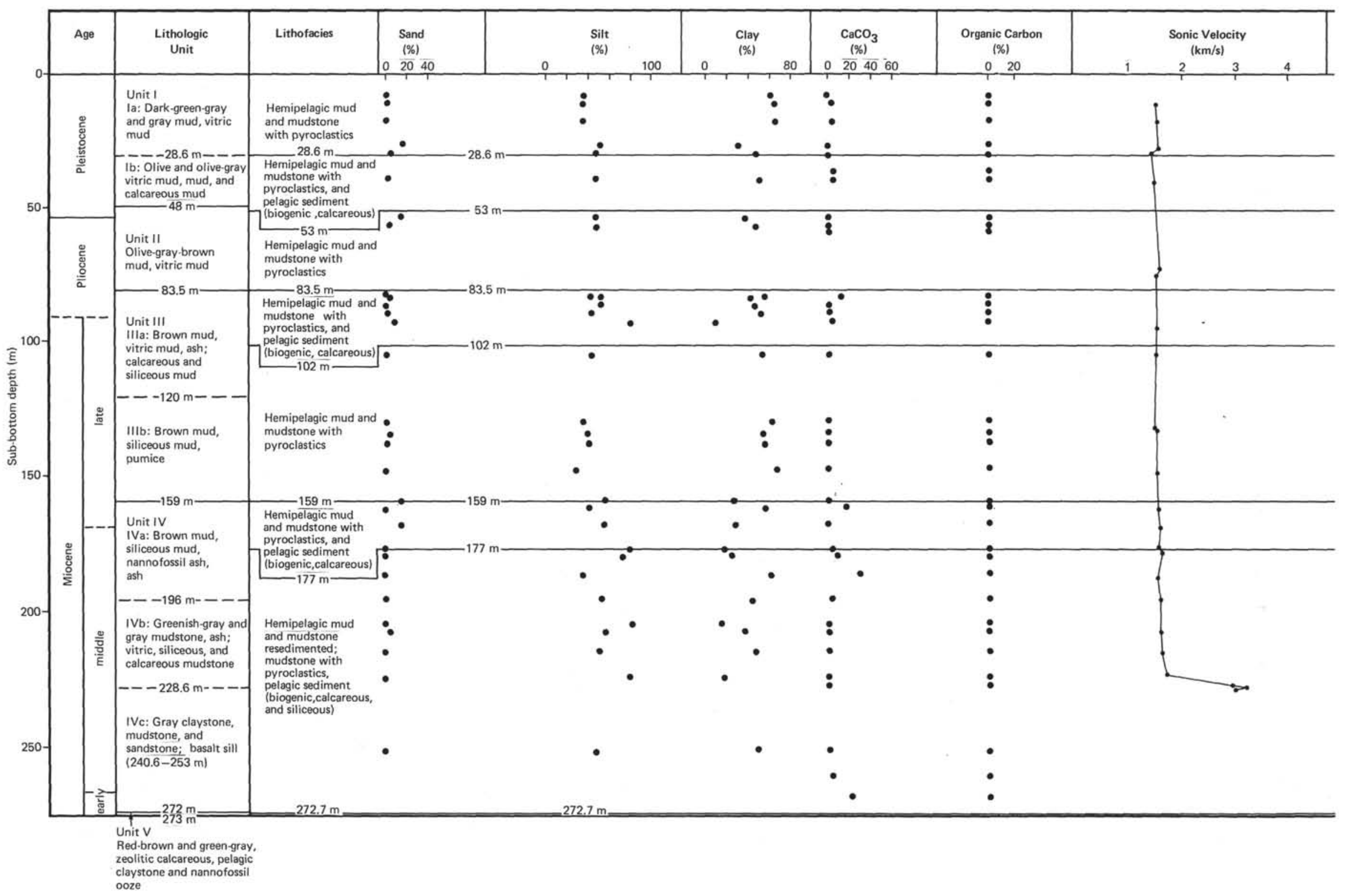

Figure 4. Stratigraphy, lithofacies, and sediment data, Site 444. 


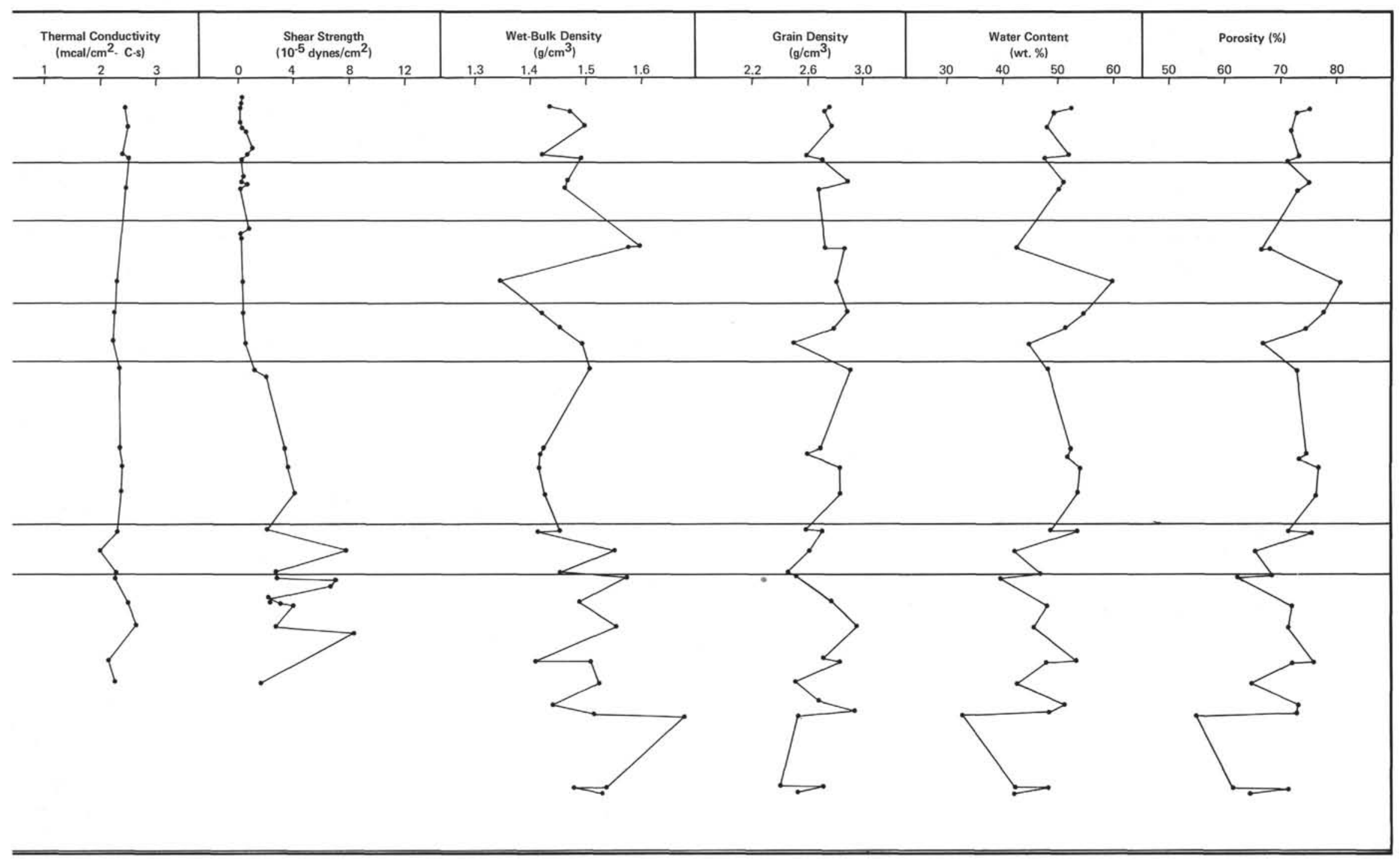

Figure 4. (Continued). 
are discontinuously common in samples from the middle Miocene to late Miocene. Foraminifers are rare or absent throughout. The depositional surface appears to have fluctuated both above and below the CCD, but it remained well below the lysocline. Deposition of the hemipelagic clays of unit II and the basal part of unit IB was below the CCD. The remaining units were deposited slightly above the CCD.

4. The sediment-accumulation rate is generally moderate throughout, the greatest rates occurring during the Pleistocene and the middle Miocene, when there was an increase in the volume of ash. The sediment accumulation rate for the unit $\mathrm{V}$ pelagic red clay is extremely low $(<1 \mathrm{~m} / \mathrm{m} . \mathrm{y}$.$) . Possible hiatuses occur at the Pliocene/$ Pleistocene and Pliocene/Miocene boundaries at the boundaries of lithologic units.

\section{Daito Ridge and Basin Region}

Two sites were drilled in the Daito Ridge and Basin region in a triangular area west of the Kyushu-Palau Ridge and east of the Ryuku Trench, in the northwest Philippine Sea. Objectives of drilling at these sites were (1) to determine the age of the oldest sediment and the basement in this region, and (2) to determine the subsidence history of the Daito Ridge. Dredge hauls on the Daito Ridge and the nearby Amami Plateau and OkiDaito Ridge recovered samples of greenschist, hornblende schist, serpentine, andesite, basalt, and granodiorite, indicating an older, highly complex igneous and metamorphic basement (Mizuno et al., 1977; Shiki et al., 1977; Yuasa and Watanabe, 1977). Younger sedimentary rocks have been reported from the dredge hauls on topographic highs. Oligocene nannofossil chalk from the eastern part of the Daito Ridge (Nishida et al., 1978) and Pliocene pelagic calcareous mudstone from the Oki-Daito Ridge (Mizuno et al., 1975) indicate that the young sediments are pelagic. Several limestone samples containing the large Eocene foraminifer Nummulites boninensis (Konda et al., 1975; Mizuno et al., 1975) from the Daito Ridge, Oki-Daito Ridge, and Amami Plateau, dredged from water depths ranging from 1160 to 2340 meters, were redeposited from Eocene shallow-water sediments.

Other objectives included determination of (1) the change in paleolatitude of the Daito Ridge and Basin area, (2) the paleocirculation of the region, and (3) the sediment distribution and sedimentation processes.

\section{Site $\mathbf{4 4 5}$}

Site 445 is in a narrow, east-west trending depression, (at a depth around 3400 meters) on the east side of the Daito Ridge; it is open toward the northwest and connected to the KitaDaito Basin through a channel. The depression is surrounded by topographic highs to the north, south, and east, with heights of 1900 to 2000 meters relative to the bottom of the depression. Continuous seismic-reflection records show accumulation of thick sedimentary fills overlying possible basement rocks. The sediments, which are for the most part acoustically well-stratified, appear to abut against the topographic highs.
A single-bit hole penetrated 892.0 meters of sediment. The stratigraphic section consists of five units (Figure 5, back pocket, this volume).

The following points characterize the sediment sequence:

1. The 892-meter-thick section represents a redeposited sequence of the middle Eocene (47-48 m.y.) to late Quaternary, interrupted by a late-Eocene/early-Oligocene hiatus. There was resedimentation of biogenic pelagic oozes and terrigenous and volcaniclastic sands and conglomerates by turbidity currents, slumping and sliding, and fluidized-sediment and debris flow. The volume of sediment deposited by resedimentation ranges from 30 to 70 per cent.

Terrigenous materials, which exclusively occupy the lowest part of the section, decrease upward and become a very minor component within the late Eocene to Quaternary. On the contrary, calcareous biogenic components (mainly nannofossils) gradually increase upward within the middle to late Eocene sequence and form an essential component of the Oligocene to Quaternary. Radiolarians are a dominant component only in the middle Eocene to late Eocene. Volcanic ash is present in the late Eocene to Quaternary sequence, but not significant; however, some intervals of the early to middle Oligocene, the late Miocene, and the Pliocene to Quaternary are relatively rich in disseminated volcanic ash and glass.

2. The sequence is dominated by various sedimentary structures related to resedimentation by turbidity currents, including graded cycles and different types of complete Bouma (1962) and partial Bouma sequences. Middle-Eocene sediments of unit $\mathrm{V}$ are characterized by other sedimentary structures characteristic of debris or fluidized-sediment flows.

3. Preservation of tropical foraminifers and nannofossils is excellent in the Pleistocene, Pliocene, and upper Miocene. However, in the lower Miocene and upper Oligocene, the foraminifers and nannofossils indicate colder waters. The Eocene fauna is tropical.

The depth of deposition was well above the CCD from the late Eocene to present, and probably above the lysocline from the latest Eocene to the present. The depth of deposition during the middle Eocene was likely at or slightly below the CCD.

4. Rates of accumulation are low for the purely pelagic intervals, moderate for the resedimented biogenic pelagic carbonates, and high for the sandstones and conglomerates of unit $\mathrm{V}$. This history of early rapid sedimentation which slows with time is similar to changes in sediment accumulation rates reported by Andrews, Packham et al. (1975) for the New Hebrides Basin (DSDP Site 286) and the South Fiji Basin (Site 285).

A slow sedimentation rate for the early Oligocene to middle Oligocene markedly interrupts the nearly continuous sedimentation from middle Eocene to Quaternary. Micropaleontology suggests that the top of the Eocene is missing at this site, which may be interpreted as a hiatus caused by nondeposition and/(or) submarine erosion during the late Eocene through early Oligocene. An Oligocene/Eocene hiatus is widespread in the southw- 
Pacific (Kennett et al., 1977) and the Indian Ocean (Davies et al., 1975); it may be a result of climatic events in Antarctica and paleocirculation changes (van Andel et al., 1975).

The hiatus at Site 445 suggests similarity of paleocirculation patterns in the Daito region to those in the southern oceans, a finding consistent with the equatorial paleolatitude of the site during deposition.

5. Paleomagnetism measurements on sediment samples illustrate a systematic change in magnetic inclination with depth (see also Kinoshita, this volume). The change in magnetic inclination indicates that the site has drifted in a net northerly direction over the last 47 m.y. At 45 to $47 \mathrm{~m}$.y. ago, the site was close to the present equator, and it has migrated nearly $2000 \mathrm{~km}$ to its present position at an average rate of $4.4 \mathrm{~cm} / \mathrm{yr}$. These data are in agreement with results obtained by Louden (1976, 1977) in the west Philippine Basin.

\section{Site 446}

Site 446 is in the Daito Basin, immediately south of the Daito Ridge and north of the Oki-Daito Ridge, in the northwestern Philippine Sea. A single-bit hole penetrated 628.5 meters of sediment, the lower portion of which was intruded by numerous basalt sills.

The stratigraphic succession (Figure 6, back pocket, this volume) consists of four lithologic units, one of which comprises sedimentary rocks interlayered with basalt sills. This lower unit (unit IV, 362.5-628.0 m) consists of interlayered dark-greenish-gray, calcareous claystone, mudstone, siltstone, and turbidite sandstone, and is the only unit with significant amounts of ash.

Some sediment interbeds overlying or underlying the basalt sills appear baked and assume dark brown to black colors. Recovered sediment types occurring as interbeds include (in general order of abundance) mudstone and claystone; glauconitic sandy mudstone, mudstone, and claystone; calcareous mudstone and claystone; ashy mudstone and siltstone; and ash and altered ash beds or zones. Sediments present in small amounts are zeolitic claystones, chalk or clayey chalk, lithic sandstones and siltstones, and chert. The sediments for the most part have the following characteristics: laminated bedding (1 mm to $1-2 \mathrm{~cm})$, silty laminations that fine upward into claystones, evidence of bioturbation, and soft-sediment deformation features; other sedimentary structures include cross-beds, graded beds, and rippled or undulating bedding surfaces.

Although basement was not reached, the age of the oldest recovered sediment is early Eocene (52 m.y.). This date suggests that, if basement is not far below the depth of penetration, the basement may be as young as early Eocene. A basalt sill at 459 to 460.5 meters was dated at $48.2 \pm 1.0$ m.y. (McKee and Klock, this volume).

Other significant facts concerning the lithology at Site 446 are:

1. Sedimentation has mostly consisted in early (mostly Eocene) resedimentation by turbidity currents, and later (latest Eocene to present) deposition of pelagic clay.
2. During the last 44 m.y., rates of sediment accumulation were very slow because of the dominance of pelagic processes, whereas during the first $8 \mathrm{~m} . \mathrm{y}$. of deposition the rates were moderate to fast because of deposition by turbidity currents (see also Andrews, Packham, et al., 1975).

3. The relative depth of deposition of the sedimentary units suggests that the depositional surface was at or just below the CCD. Deposition was clearly below the CCD during deposition of the clays in units I and II. Although calcareous foraminifers and nannofossils were recovered, they were poorly preserved and appear to have been reworked by currents. During deposition of unit III, when turbidite deposition prevailed, reworked nannofossils are common, suggesting that the depositional depth of this unit was also below the CCD. Most of unit IV was also deposited below the CCD.

4. Paleomagnetism of the sediments and sedimentary rocks indicates that the site drifted in a net northerly direction over the past 52 million years, and has migrated nearly $2000 \mathrm{~km}$ to its present position. These data are in agreement with paleomagnetism measurements by Louden $(1976,1977)$ from the west Philippine Basin. (See Kinoshita, this volume.)

\section{SEDIMENTARY FACIES}

Six major lithofacies and seven subordinate lithofacies were recognized in Leg 58 cores (Tables 1 and 2). These facies were distinguished by grain-size distribution, mineralogy, lithology, association of sedimentary structures and fabric, and mode of origin. Subdivision of lithofacies in this paper follows designations commonly used in sedimentological studies of outcrops on land, such as those suggested by DeRaaf et al. (1965) and subsequently extended to studies of DSDP cores by Berger and von Rad (1972) and Klein (1975a,b), among others. Figures 2 to 6 portray the vertical distribution of these facies at each drill site.

\section{Hemipelagic Clay Facies}

Hemipelagic sediments (clays) are the most common sediments recovered in Leg 58 cores, especially at Sites

TABLE 1

Lithofacies Recognized in Leg 58 Sediment Cores

\begin{tabular}{ll}
\hline \multicolumn{1}{c}{ Major Facies } & \multicolumn{1}{c}{ Subordinate Facies } \\
\hline Hemipelagic & $\begin{array}{l}\text { Hemipelagic clay } \\
\text { Hemipelagic mudstone }\end{array}$ \\
Resedimented clastic & $\begin{array}{l}\text { Resedimented mudstone } \\
\text { Resedimented sandstone } \\
\text { Resedimented conglomerate }\end{array}$
\end{tabular}

Resedimented carbonate

Pelagic non-biogenic

Pelagic biogenic

Calcareous pelagic biogenic Siliceous pelagic biogenic

Pyroclastic 
TABLE 2

Lithofacies by Depth at Leg 58 Sites

\begin{tabular}{|c|c|c|c|}
\hline & \multirow{2}{*}{$\begin{array}{l}\text { Sub-bottom } \\
\text { Depth } \\
\text { (m) }\end{array}$} & \multicolumn{2}{|c|}{ Lithofacies } \\
\hline & & Major & Minor \\
\hline \multirow[t]{3}{*}{ Site 442} & $\begin{array}{l}0-123.5 \\
123.5-256\end{array}$ & $\begin{array}{l}\text { Hemipelagic mudstone } \\
\text { Hemipelagic mudstone }\end{array}$ & Pyroclastic \\
\hline & $256-276$ & $\begin{array}{l}\text { Pyroclastic } \\
\text { Pys }\end{array}$ & Hemipelagic mudstone \\
\hline & $276-286.7$ & Pelagic non-biogenic & Calcareous pelagic biogenic \\
\hline \multirow[t]{12}{*}{ Site 443} & $0-44.8$ & Hemipelagic mudstone & Pyroclastic \\
\hline & $45-121$ & Hemipelagic mudstone & Pyroclastic \\
\hline & $121-181$ & Hemipelagic mudstone & Pyroclastic \\
\hline & $181-199$ & Hemipelagic mudstone & \\
\hline & $199-216$ & Hemipelagic mudstone & $\begin{array}{l}\text { Calcareous pelagic biogenic } \\
\text { Pyroclastic }\end{array}$ \\
\hline & $217-233$ & Hemipelagic mudstone & Calcareous pelagic biogenic \\
\hline & $233-263.5$ & Hemipelagic mudstone & \\
\hline & $263.5-314$ & Hemipelagic mudstone & Pyroclastic \\
\hline & $314-358$ & Hemipelagic mudstone & Calcareous pelagic biogenic \\
\hline & $358-447$ & Hemipelagic mudstone & \\
\hline & & Resedimented mudstone & \\
\hline & & Pyroclastic & \\
\hline & $447-457$ & Hemipelagic mudstone & \\
\hline & & Pyroclastic & \\
\hline & & Calcareous pelagic biogenic & \\
\hline \multirow[t]{13}{*}{ Site 444} & $0-30$ & Hemipelagic mudstone & Pyroclastic \\
\hline & $30-53$ & Hemipelagic mudstone & Pyroclastic \\
\hline & & & Calcareous pelagic biogenic \\
\hline & $53-83.5$ & Hemipelagic mudstone & Pyroclastic \\
\hline & $83.5-102$ & Hemipelagic mudstone & Pyroclastic \\
\hline & & & Calcareous pelagic biogenic \\
\hline & $102-158$ & Hemipelagic mudstone & Pyroclastic \\
\hline & $158-177$ & Hemipelagic mudstone & Pyroclastic \\
\hline & & & Siliceous pelagic biogenic \\
\hline & $177-272.7$ & Hemipelagic mudstone & \\
\hline & & Resedimented mudstone & Pyroclastic \\
\hline & & & Calcareous pelagic biogenic \\
\hline & & & Siliceous pelagic biogenic \\
\hline \multirow{15}{*}{ Site 445} & & & \\
\hline & $0-141.8$ & Calcareous pelagic biogenic & Pyroclastic \\
\hline & $141.8-208$ & Resedimented carbonate & Calcareous pelagic biogenic \\
\hline & 208-303 & Resedimented carbonate & $\begin{array}{l}\text { Calcareous pelagic biogenic } \\
\text { Pyroclastic }\end{array}$ \\
\hline & $303-518$ & Resedimented carbonate & Calcareous pelagic biogenic \\
\hline & $518-549$ & Resedimented carbonate & Calcareous pelagic biogenic \\
\hline & $549-609$ & Resedimented carbonate & Calcareous pelagic biogenic \\
\hline & & & Siliceous pelagic biogenic \\
\hline & & & Hemipelagic clay \\
\hline & & & Pyroclastic \\
\hline & $609-645$ & Siliceous pelagic biogenic & \\
\hline & $645-660$ & Siliceous pelagic biogenic & Resedimented conglomerate \\
\hline & $660-888$ & Resedimented mudstone & \\
\hline & & Resedimented sandstone & \\
\hline & & Resedimented conglomerate & Calcareous pelagic biogenic \\
\hline \multirow[t]{13}{*}{ Site 446} & $0-40$ & Hemipelagic clay & Pelagic non-biogenic \\
\hline & $40-116$ & Hemipelagic clay & Pelagic non-biogenic \\
\hline & & & \\
\hline & $116-173$ & Hemipe lagic clay & Pelagic non-biogenic \\
\hline & & Resedimented mudstone & $\begin{array}{l}\text { Hemipelagic mudstone } \\
\text { Calcareous pelagic biogenic }\end{array}$ \\
\hline & $362.5-514$ & (as interbeds) & \\
\hline & & Resedimented mudstone & Pyroclastic \\
\hline & & & Hemipelagic mudstone \\
\hline & & & Calcareous pelagic biogenic \\
\hline & & & Resedimented sandstone \\
\hline & & & Resedimented conglomerate \\
\hline & $514-630$ & (as interbeds) & \\
\hline & & Resedimented mudstone & Hemipelagic mudstone \\
\hline
\end{tabular}

442, 443, and 444 (early Miocene to Pleistocene), in the Shikoku Basin. Variably colored (brown, yellow, gray, green) according to site location and age, they consist chiefly of terrigenous clay from volcanic arcs, the Japanese Islands, and continental Asia. The dominant sources of clay changed with time, because of variations in volcanism, tectonic activity, and continental climates (see Chamley, this volume). Clay minerals, dominated by smectite or illite, are accompanied by detrital feldspars, quartz, and micas, and sometimes by amphiboles and other heavy minerals. Volcanic material occurs throughout the sedimentary column at all drill sites, consisting chiefly of glass. Its proportion is generally low, but in some intervals, especially the oldest, distinct ash or glass levels exist. (See section on pyroclastic facies.) Calcareous and siliceous tests are often poorly preserved, likely because of dissolution, except at Site 445 (depth less than $3400 \mathrm{~m}$ ). Calcareous nannofossils are the most frequent component, followed by radiolarians, planktonic foraminifers, and diatoms. Variations in the proportion of organic debris depend on changes in the CCD with time and on plankton productivity, or dilution by terrigenous material.

\section{Resedimented Clastic Facies}

\section{Resedimented Mudstone}

The resedimented mudstone facies occurs as interbeds with hemipelagic clays at Sites 443 and 444 in the Shikoku Basin, and as interbeds with the resedimented conglomerate and resedimented sandstone facies at Site 445 (Daito Ridge) and Site 446 (Daito Basin) (Table 2).

The main attributes of the mudstone that indicate resedimentation are the variety of very small-scale sedimentary structures. These include thin $(2-\mathrm{cm})$ graded beds of siltstone; parallel laminae of alternating silt and clay (Plate 1, Figure 1); fining-upward gradation of volcanic-ash laminae into siltstone and claystone laminae; micro-cross-laminae; and sporadic thin breccia zones consisting of intraformational clay. At Site 445, intervals of the resedimented mudstone facies which are arranged in slump blocks or slump folds commonly contain interbedded mudstone layers, which suggests resedimentation by gravity processes. In addition, the association of this facies with the resedimented sandstone facies and the resedimented conglomerate facies further indicates resedimentation in the formation of these mudstones.

\section{Resedimented Sandstone}

The resedimented sandstone facies occurs at both Sites 445 and 446 (Table 2). It consists of thin to medium-thick layers of sandstone ranging in grain size from very coarse sand $(2 \mathrm{~mm})$ to very fine sand $(1 / 16$ $\mathrm{mm})$. Conglomeratic sandstones are also present, particularly at Site 445; clasts never exceed fine-pebble size. Most sands are moderately well sorted; individual clasts are sub-rounded to angular.

The sandstone is compositionally variable, but dominantly volcaniclastic, with recognizable fragments of andesite, phyric basalt, aphyric basalt, and microdolerite. Augite, detrital olivine, orthopyroxene, and clinopyroxene were also observed. Clasts of Nummulities boninensis, oolites, pelecypods, and limestone are also present. These sandstones show complex diagenetic and cementation change with depth (discussed more fully by Klein et al., this volume).

The resedimented sandstone facies shows a variety of sedimentary structures, including parallel laminae, graded bedding, micro-cross-laminae, dish structures, 
load casts, slump folds, micro-faults, and slump faults. Many of these structures are organized into partial or complete Bouma sequences.

Dish structures. A volcaniclastic-bioclastic sandstone at 445-57-7, 0-40 cm contained dish structures (Plate 1, Figure 2). These dish structures are concave upward and demarcated by finer-grained sediment. These dish structures appear to be related to debris flow: grain flow and internal shear (Stauffer, 1967), fluid escape (Lowe, 1976; Lowe and LoPiccolo, 1974), and later shearing action on unstable surfaces of a debris flow. Later resedimentation smooths slope surfaces on such a flow to produce the dish structures (Busch, 1976a,b). Busch's mechanism applies to the dish structures observed at Site 445 .

Load casts. Load casts are common in the resedimented sandstone facies, particularly at the base of sandstone overlying mudstone, or at the basal contact of Bouma sequences, such as at $445-89-2,73 \mathrm{~cm}$. The load casts are formed by rapid deposition of the overlying sediment on soft, water-saturated clay and ash.

Microfaults. Microfaults occur within very thin sandstone beds (Plate 1, Figure 3). Vertical displacement on these faults is on the order of $5 \mathrm{~mm}$. The microfaults cut across bedding almost at right angles to the bedding planes, indicating tension related to intrabed slumping.

Slump blocks and slump folds. Thick intervals of slump folds and slump faults are very common within the resedimented sandstone facies. Cores show inclined laminae truncated at the base and the top by horizontal laminae, clearly indicating large-scale mass movement by slumping of certain intervals. Similar slump folds with near-horizontal or steeply inclined fold axes $\left(70^{\circ}\right.$ from horizontal) are common, and the folded intervals ranged from 3 to 5 meters thick. Such intervals also were truncated by horizontally laminated sediment. Both the inclined stratified zones and the folded zones indicate transport of sediment by slumping along unstable depositional slopes.

Graded bedding. This structure is very common in the resedimented sandstone facies and generally is characterized by a sharp basal contact with underlying sediments. The grain-size changes observed in graded beds is either from small pebble gravel to medium sand, or from coarse sand to a very fine sand or coarse silt. Graded beds are transitional into overlying units, which may consist of parallel-laminated sand or resedimented mudstone or siltstone.

The graded beds show a broad range of thickness, ranging from $1 \mathrm{~cm}$ to 1.3 meters. The graded beds less than $30 \mathrm{~cm}$ thick show a particle-size range from a basal coarse-grained sandstone to a fine-grained sandstone at the top (Plate 1, Figure 4), whereas graded beds thicker than $30 \mathrm{~cm}$ tend to show a size range from a basal conglomerate of fine pebble size to coarse sandstone at the top (Plate 2, Figure 1). These graded beds generally pass upward into finer-grained siltstone or mudstone (Plate 2, Figure 2).
Most of the graded beds comprise parts of Bouma sequences (Plate 1, Figure 1; Plate 2, Figure 1) and clearly are due to deposition by turbidity currents.

Parallel laminae. Parallel laminae are common in the resedimented sandstone (Plate 2, Figure 1), or as the $\mathrm{T}_{\mathrm{b}}$ interval of partial or complete Bouma sequence (Plate 1, Figure 1; Plate 2, Figure 2). In both instances, the parallel laminae are separated by distinct changes in grain size from coarse- to medium-grained sand or medium- to fine-grained sand. Parallel laminae independent of Bouma sequences also show alternating layers of thin sand laminae and clay laminae, or clay laminae and nannofossil-rich laminae, such as at 445-68-1, 93-94 $\mathrm{cm}$.

The origin of the parallel laminae appears to be twofold. Laminae independent of Bouma sequences probably were deposited by ocean currents characterized by regular velocity fluctuations. The parallel laminae associated with Bouma sequences resulted from deposition by decelerating turbidity currents.

Micro-cross-laminae. This sedimentary structure occurs invariably as part of complete or partial Bouma sequences, representing the $T_{c}$ interval. The micro-crosslaminae are distinguished by textural, color, and compositional changes for each lamina (Plate 1, Figure 1; Plate 2, Figure 1). Grain-size changes between such laminae normally range from medium sand to fine sand. Some of the micro-cross-laminae are oversteepened into convolute laminae (Plate 2, Figure 1).

The micro-cross-laminae are related to deceleration of turbidity currents.

Vertical sequences. The sedimentary structures observed in the resedimented sandstone facies are organized into preferred sequences showing a systematic vertical change in grain size, lithology, and sedimentary structures. The observed sequences represent complete or partial Bouma sequences. Two examples of such sequences are shown in Plate 1, Figure 1 and Plate 2, Figure 1 .

The origin of Bouma sequences has been debated since they were described in detail by Bouma (1962) and interpreted hydraulically by Walker (1965). Basically, the sequence records deposition by a decelerating turbidity current showing diminishing flow velocity, competence, and capacity. Such sequences commonly are related to submarine fans (Nelson and Kulm, 1973; Walker and Mutti, 1973; Walker, 1978). Complete sequences normally are limited to the submarine-channel zone, partial sequences indicating either levee overspill deposition, or deposition in suprafan lobes or in distal zones. In our opinion, these processes account for the presence of the Bouma sequences observed in this facies.

The resedimented sandstone facies appears to be related to deposition by turbidity currents on submarine fans. The source of the sediments was the remnant arcs of the Daito Ridge and Oki-Daito Ridge. Deposition by these turbidity currents occurred on submarine fans which filled the small sediment pond on the Daito Ridge 
at Site 445 , and which prograded basinward in the Daito Basin, an inner-arc basin.

\section{Resedimented Conglomerate Facies}

The resedimented conglomerate facies occurs at both Sites 445 and 446 (Table 2).

The resedimented conglomerate facies consists of thin to medium-thick layers of conglomerate. The clasts range from granules to small cobbles, and are either dispersed and enclosed in a matrix of volcaniclastic sandstone and mudstone or are in framework contact Plate 2, Figure 3 and 4). In one instance, resedimented conglomerates are imbricate in the basal portion of Bouma sequences of turbidite sandstone of the resedimented sandstone facies (Plate 2, Figure 1). Framework conglomerates comprise also the basal graded portion of several partial and complete Bouma sequences.

The mineralogy of the conglomerate is varied; there are two compositional categories. One category is dominated by fossil fragments consisting mostly of complete or broken fragments of the larger foraminifer Nummulites boninensis. In addition, other foraminifers commonly occur in the matrix, and pelecypod fragments, algal fragments, and oolites have been reported. Rounded limestone clasts also occur. The second compositional category comprises volcaniclastic grains. These are mostly basaltic but include micro-dolerite, andesite, phyric basalt, and aphyric basalt, all of oceanic-crust and island-arc derivation. In addition, some clasts of schist, gneiss, and granodiorite were present. Our observations are consistent with rocks obtained by dredge hauls from the Daito Ridge and the Oki-Daito Ridge by Mizuno et al. (1977) and by Shiki et al. (1977) (Table 3).

This facies shows almost no sedimentary structures, although a few samples show a crude fabric on the core surfaces. Most of the conglomerates correspond to Walker's (1975) disorganized-bed model: random orientation of clasts either in framework contact or dispersed (Plate 2, Figure 3). Imbrication of clasts was observed in some of these disorganized units (Plate 2, Figure 4) although opposite-dipping imbrication was found at one horizon (Plate 2, Figure 3). Most of this particle alignment is emphasized by the shape of fragments of Nummulites boninensis, but that alignment also parallels the orientation of associated disc-shaped clasts of volcaniclastic material and limestone fragments (Plate 2, Figure 3).

Imbricated and stratified conglomerates conforming to Walker's (1975) graded stratified model were observed in association with the basal portion of Bouma sequences, both partial and complete, in interbedded resedimented sandstones (Plate 3, Figure 1). Normal grading and a suggestion of reversed grading occur within this basal conglomerate zone, which corresponds to both the Bouma $T_{a}$ and $T_{b}$ intervals (Plate 3, Figure $1)$.

The resedimented conglomerate facies very clearly was emplaced in both a small sediment pond on the remnant arc of the Daito Ridge (Site 445) and in an innerarc basin (Daito Basin) (Site 446). Sedimentation clearly was by subaqueous gravity processes, including both
TABLE 3

Summary of Resedimented-Conglomerates from Site 445 and Dredge Hauls from the Daito Ridge

\begin{tabular}{|c|c|c|c|c|}
\hline \multirow{2}{*}{\multicolumn{2}{|c|}{ Rock Type }} & \multicolumn{2}{|c|}{ Site 445 (Unit V) } & \multirow[b]{2}{*}{$\begin{array}{l}\text { Dredge Hauls from the } \\
\text { Daito Ridge }\end{array}$} \\
\hline & & Lithic Clasts & $\begin{array}{l}\text { Detrital } \\
\text { Minerals }\end{array}$ & \\
\hline \multirow{4}{*}{ Igneous } & Basalt & $\begin{array}{l}\text { Plagioclase } \\
\text { phyric basalt } \\
\text { Micro-dolerite } \\
\text { Apyric basalt } \\
\text { Plagioclase } \\
\text { clinopyroxene } \\
\text { phyric basalt }\end{array}$ & $\begin{array}{l}\text { Plagioclase } \\
\text { Augite }\end{array}$ & Dolerite \\
\hline & $\begin{array}{c}\text { Alkali } \\
\text { basalt }\end{array}$ & - & $\begin{array}{l}\text { Aegirine } \\
\text { Titaniferous } \\
\text { augite }\end{array}$ & \\
\hline & Andesite & - & $?$ & $\begin{array}{l}\text { Two-pyroxene andesite } \\
\text { Hornblende andesite } \\
\text { Augite andesite }\end{array}$ \\
\hline & $\begin{array}{l}\text { Grano- } \\
\text { diorite }\end{array}$ & - & $?$ & $\begin{array}{l}\text { Hornblende-biotite } \\
\text { granodiorite }\end{array}$ \\
\hline \multicolumn{2}{|c|}{ Ultrabasic } & - & $\begin{array}{l}\text { Picotite } \\
\text { Diopside } \\
\text { Enstatite } \\
\text { Magnetite } \\
\text { Serpentine } \\
\text { pseudomorph } \\
\text { after olivine }\end{array}$ & $\begin{array}{l}\text { Peridotite } \\
\quad \text { (metamorphosed) }\end{array}$ \\
\hline \multicolumn{2}{|c|}{ Metamorphic } & Hornblende schist & $\begin{array}{l}\text { Green } \\
\text { hornblende } \\
\text { Epidote } \\
\text { Magnetite } \\
\text { IImenite } \\
\end{array}$ & $\begin{array}{l}\text { Epidote-hornblende } \\
\text { schist } \\
\text { Hornblende schist }\end{array}$ \\
\hline \multicolumn{2}{|c|}{ Sedimentary } & $\begin{array}{l}\text { Chert } \\
\text { Nummulites-bearing } \\
\text { limestone } \\
\text { Sandstone }\end{array}$ & $?$ & $\begin{array}{l}\text { Nummulites-bearing } \\
\text { limestone } \\
\text { Sandstone } \\
\text { Claystone } \\
\text { Calcareous rock }\end{array}$ \\
\hline \multicolumn{2}{|l|}{ Biogenic } & $\begin{array}{l}\text { Nummulites } \\
\quad \text { boninensis } \\
\text { Asterocyclina sp. } \\
\text { Penuria } \\
\text { Operulinoides sp. }\end{array}$ & - & $\begin{array}{l}\text { Nummulites honinensis } \\
\text { Asterocyclina sp. } \\
\text { Discocyclina sp. }\end{array}$ \\
\hline
\end{tabular}

debris flow deposition, represented by the disorganized conglomerates and conglomerates showing a dispersedclast fabric, and the transition from debris flow to a turbidity current, represented by the imbricated and stratified conglomerates associated with Bouma sequences. The source of the sediments was the island arc now represented by the Daito Ridge and the Oki-Daito Ridge. Both volcanic material and coastal carbonate deposits were transported from a shoreline and island setting into deeper water by these processes.

\section{Resedimented Carbonate Facies}

The resedimented carbonate facies was observed only at Site 445 on the Daito Ridge; it is interbedded with the pelagic biogenic carbonate facies, the biogenic siliceous facies, and the hemipelagic clay facies (Table 2).

The resedimented carbonate facies consists of foraminifer-nannofossil oozes, chalks, and limestones; nannofossil-foraminifer oozes, chalks, and limestones; and interbedded laminae and beds of volcanic-ash-rich ooze, chalk, and limestone. The carbonate grains range from medium sand to clay, depending on the proportions of foraminifers and nannofossils in the sample. These carbonates consist mostly of calcite shells of foraminifers and nannoplankton; they contain accessory hemipelagic 
clay and, in some horizons, interbeds of volcanic ash and sand-sized volcanic-rock fragments.

This facies is characterized by many types of sedimentary structures and fabric, indicating a variety of resedimentation processes by subaqueous gravity flows. Among the observed structures and fabrics were distorted burrows, microfaults, slump folds, slump blocks, load casts, graded bedding, parallel laminae, and microcross-laminae. Many of these structures are organized into partial or complete Bouma sequences and show definite affinities with identical structures in the resedimented sandstone facies.

Distorted burrows. Some of the bioturbated zones show evidence of shearing and disruption as a result of resedimentation. Plate 3 , Figure 2 shows part of a core consisting of bioturbated, clayey nannofossil ooze, in which the upper part of the bioturbated zone is undisturbed, but the lower part is sheared, and the burrows are distorted and smeared. The distorted burrows are aligned in parallel and demarcate a crude type of laminar structure. These types of disturbed bioturbated intervals are fairly common in the resedimented carbonate facies and suggest a mode of transport of some of this facies by debris flow. The disturbed zone represents the laminar-flow zone associated with debris flows (Hampton, 1972), whereas the overlying undisturbed interval may well represent the rigid plug of this debris flow.

Microfaults. Microfaults were observed in resedimented chalks and limestones and occur in beds which show sedimentary structures generated by slumping. The microfaulted intervals are generally confined to thin beds of clayey limestone and the enclosing layers (Plate 3, Figure 3). The microfaults cut bedding nearly at right angles. Some of the faulted blocks show evidence of rotation. We interpret these microfaults to represent a phase of tensional deformation associated with down-slope slumping.

Slump structures. Many varieties of slump structures were observed in the resedimented carbonate facies. These included slump fractures (or faults), slump blocks, blocks, and slump folds. Each of these structures occurs in intervals ranging from $10 \mathrm{~cm}$ to 3 meters in thickness and are demarcated above and below by horizontally bedded carbonate. Slump folding (Plate 3, Figure 4) is accentuated by changes in bedding controlled by changes in color and composition and invariably shows fold axial planes inclined 10 to 20 degrees from the horizontal. Slump blocks (Plate 4, Figure 1) range from $2 \mathrm{~cm}$ to 2 meters in diameter and are usually set off from enclosing sediment by changes in color and composition.

Vertical slump fractures are also common, either as bounding surfaces of slump blocks, or as planes intersecting bedding, other sedimentary structures, or partial Bouma sequences (Plate 4, Figure 2). These fractures tend to be oriented normal to bedding and show single or compound vertical displacements ranging from 0.5 to $3 \mathrm{~cm}$. They appear as a syndepositional or post depositional resedimentation structure.

It is our interpretation that these structures are interpreted to have formed during down-slope mass trans- port of sediment by sliding and slumping on unstable slopes.

Load casts. Load casts were observed in the resedimented carbonate facies where carbonate rock lithologies were overlying interbedded volcanic ash with sharp contact. The limestones and chalks overlying the loadcast contact showed well-developed slump folds, slump blocks, or slump fractures, indicating rapid deposition of carbonate sediments on water-saturated ash beds. The load casts represent a physical record of this event of rapid deposition.

Graded bedding. Graded bedding is one of the most common sedimentary structures in the resedimented carbonate facies. Graded bedding always overlies a sharp contact and grades upward into the overlying sediment. Grading tends to be coarse-tail, and graded intervals range from 0.5 to $20 \mathrm{~cm}$ in thickness.

The graded bedding is defined by a transition from nannofossil-foraminifer ooze, chalk, or limestone into a foraminifer-nannofossil ooze, chalk, or limestone. These graded beds occasionally contain up to 15 per cent siliceous or terrigenous and volcaniclastic grains (Plate 4, Figure 3). Most of these graded beds pass upward into a clayey nannofossil ooze, chalk, or limestone with a gradational contact. Most of the graded beds comprise parts of complete or partial Bouma sequences (Plate 4, Figure 2) and were deposited by turbidity currents.

Parallel laminae. This structure is also very common in the resedimented carbonate facies. The parallel laminae are demarcated by changes in grain size from foraminifer-rich to nannofossil-rich zones and from bioclastic constituents to clayey limestones, by alternation of carbonate and volcaniclastic components (Plate 4, Figure 3; Plate 5, Figure 1), and (as disclosed by radiography) by alternation of carbonate laminae with hemipelagic clay laminae (Plate 5, Figure 1). Some of these laminae appear as faint, discontinuous laminae on core surfaces, but are shown to be continuous by a radiography (Plate 5, Figure 1). Most of the parallel laminated beds comprise complete or partial Bouma sequences, and they were produced by deposition from turbidity currents.

Micro-cross-laminae. Micro-cross-laminae also occur in the resedimented carbonate facies. The laminae are demarcated by changes in grain size from foraminifer-rich sand to nannofossil-rich clay and silt-sized particles, or by changes in composition from carbonate to clay or from carbonate to volcaniclastic grains. Some of these micro-cross-laminae occur in lenses (Plate 1, Figure 1) and appear only in radiographs. A few intervals of micro-cross-laminae also grade laterally into convolute laminae (Plate 6, Figure 1). The micro-crosslaminae comprise part of complete or partial Bouma sequences and were deposited by turbidity currents.

Vertical sequences. The lithologies, grain sizes, and sedimentary structures observed in the resedimented carbonate facies are organized into distinct vertical sequences. One of these sequences is a resedimented-debris-flow sequence consisting of a basal clayey nanno- 
fossil limestone containing disrupted burrows and overlying identical limestone with undisturbed burrows. This sequence indicates transport by debris flow, and the transition in the nature of the burrows suggests a lower laminar-flow phase of debris-flow transport, whereas the undisturbed upper phase indicates a rigidplug phase of the same debris flow.

By far the most common sequence is the partial Bouma sequence; a few complete Bouma sequences were observed. In the resedimented carbonate facies, these members are preserved, although complete sequences are rare. The most commonly preserved partial sequence consists of the basal graded interval $\left(\mathrm{T}_{\mathrm{a}}\right)$, the parallel-laminated interval $\left(\mathrm{T}_{\mathrm{b}}\right)$, and the pelagic interval $\left(T_{e}\right)$ (Plate 4, Figure 2). A second common type of partial sequence (Plates 5 and 6) shows a basal parallellaminated interval $\left(\mathrm{T}_{\mathrm{b}}\right)$ overlain by the micro-crosslaminated interval $\left(\mathrm{T}_{\mathrm{c}}\right)$, capped by the pelagic-clay interval $\left(T_{e}\right)$. These sequences indicate resedimentation by turbidity currents.

The most noteworthy aspect of this facies is its thickness. Other resedimented carbonates have been reported by Klein (1975a, b) and Cook et al. (1976) from other DSDP sites, but the examples they report involve restricted, thin intervals perhaps no more than 100 meters thick. At Site 445, resedimented carbonates reach a total thickness of 468 meters. Within this interval, thin, pelagic, clayey, biogenic, carbonate beds comprise the $\mathrm{T}_{\mathrm{e}}$ interval of Bouma sequences. Fully 80 per cent of this 468-meter interval consists of resedimented carbonate sediment. Resedimentation was by debris flow, slumping, sliding, and turbidity currents.

\section{Pelagic Non-Biogenic Facies (IV)}

Pelagic clays occur in fairly thin sequences in the Shikoku Basin at Site 442 (Holes 442A and 442B), and Site 444 , representing some of the first sediments deposited in the basin. They consist of firm, dark-brown, more or less bioturbated clay to claystone; they contain clay minerals (chiefly smectite), amorphous metal oxides, often manganese-iron micronodules, and sometimes zeolites. At Site 444, a reddish-brown mudstone overlying the last basalt sill includes a variable amount of calcareous nannofossils.

The pelagic clay facies also occurs in the Daito Ridge area at Site 446, in the late Eocene and late Miocene. This facies consists of dark-brown to very dark-grayishbrown clay with 95 per cent or more clay-sized particles. The sediments chiefly include clay minerals, sometimes with zeolites and micronodules; however, throughout they also contain small amounts of quartz, feldspars, volcanic glass, carbonates, and sometimes siliceous fossils and chert, suggesting a non-typical pelagic sedimentation.

\section{Pelagic Biogenic Facies}

The pelagic biogenic facies occur as mostly biogenic oozes (calcareous or siliceous) or as transitional subfacies.

Distribution of the pelagic biogenic facies in the Leg 58 holes is shown in Table 4. The tabulation does not reflect the type of occurrence for the facies (lens, bed, etc.) but simply records the presence or absence of the facies within the cored intervals. A general description of this facies is mose simply presented as follows:

$\begin{array}{lc}\text { Biogenic siliceous a,b,f } & >30 \% \text { Siliceous skeletons } \\ & <30 \% \text { Non-biogenic compon- } \\ \text { ents (silt and clay) } & <30 \% \mathrm{CaCO}_{3}\end{array}$

aSee Introduction to this volume.

boze, diatomite, radiolarite, porcellanite, chert.

'Ooze, chalk, limestone.

${ }^{\mathrm{d} S}$ Sand, silt, clay, mud, or indurated equivalent (shale, if fissile).

'Siliceous modifer if $10-20 \%$ identifiable siliceous remains.

${ }^{\mathrm{f}} \mathrm{Calcareous}$ modifer if $10-30 \% \mathrm{CaCO}_{3}$.

\section{Site 442}

The transitional siliceous facies occurs only in the uppermost Pleistocene and Miocene cores at the site. It is a siliceous mud with diatoms, radiolarians, and sponge spicules and up to 20 per cent volcanic glass. The colors are dark gray and dark greenish gray, extremely mottled because of drilling disturbance.

The calcareous facies has a very minor occurrence as a nannofossil-rich mud and limestone (Table 4). The latter overlies lightly weathered aphyric basalt and redbrown pelagic mud. This limestone (early Miocene), is attributed to inorganic precipitation or recrystallization of a nannofossil ooze by low-temperature diagenesis or thermal metamorphism (Fischer, Heezen, et al., 1971).

Foraminifers encountered in Holes 442, 442A, and 442B are sporadic and poorly preserved. Well- to moderately well-preserved nannofossils of the Quaternary and early to middle Miocene were recovered. The occurrence of nannofossils at this site is similar to that of Site 297 (Leg 31), except for the absence of Pliocene nannofossils at Site 442 .

\section{Site $\mathbf{4 4 3}$}

Except for the transitional siliceous facies in Core 31 (4.5 meters of gray-brown, upper-Miocene siliceous mudstone; diatoms $>$ radiolarians $>$ spicules) and the biogenic calcareous facies in Core 35 (olive-gray, middle- or upper-Miocene nannofossil chalk), the transitional calcareous facies dominates (Table 4). 
TABLE 4

Distribution of Pelagic Biogenic Facies, Leg $58^{\mathrm{a}}$

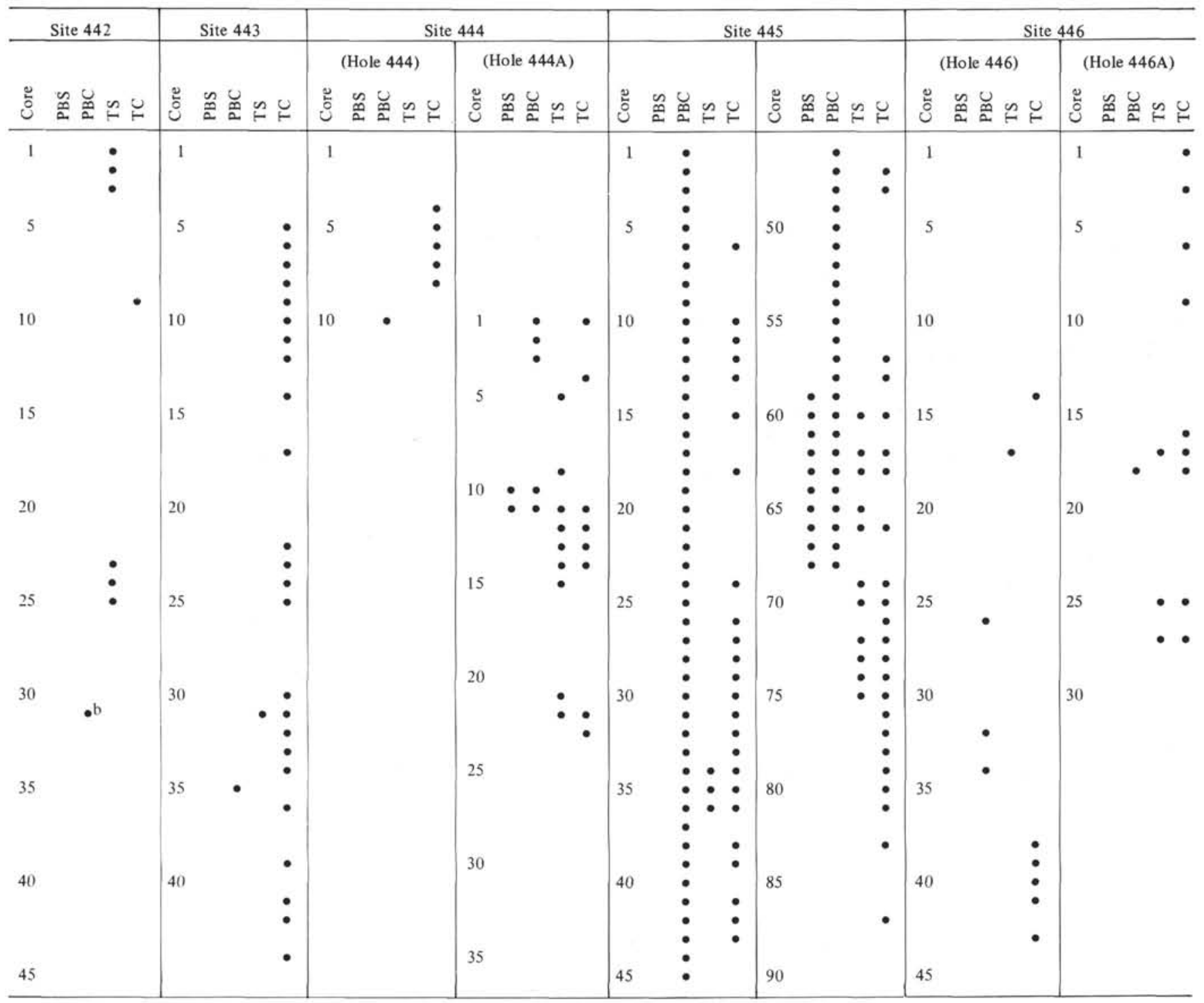

${ }^{a}$ Symbols $($ see text): PBS $=$ pelagic biogenic siliceous; $\mathrm{PBC}=$ pelagic biogenic calcareous; $\mathrm{TS}=$ transitional siliceous $; \mathrm{TC}=$ transitional calcareous; $\bullet=$ presence of

bimestone above basalt.

The Pleistocene sequence contains the transitional calcareous facies as a predominantly dark-green-gray nannofossil mud (up to $40 \%$ nannofossils) to a darkgreen-gray to dark-gray carbonate mud (up to $15 \%$, $\mathrm{CaCO}_{3}$ ) with minor ash intervals. The Pliocene is represented by 2 to $30-\mathrm{cm}$ units of gray, calcareous mud and nannofossil mud, interbedded with more-massive units of ashy mud. Facies in the Miocene consist of nannofossil muds and nannofossil mudstones and claystones with clayey nannofossil chalks, generally olive gray, gray, or green gray. A restricted Miocene biogenic facies is represented by olive-gray nannofossil chalk (up to $90 \%$ nannofossils). Core 36 to the first cored basalt contain beds up to 3 meters thick of nannofossil claystone and mudstone, as well as clayey nannofossil chalk. Interbeds are mudstone, claystone, and ashy mudstone and claystone.

\section{Site $\mathbf{4 4 4}$}

Upper-Miocene to Quaternary deposits at Site 444 primarily contain the transitional calcareous and biogenic calcareous facies. Below the middle Miocene at Hole 444A, only the transitional and biogenic calcareous facies are present.

Calcareous facies at Holes 444 and 444A consist of calcareous muds, nannofossil muds, clayey nannofossil ooze, nannofossil ooze, and nannofossil mud. All deposits are brown (olive brown, pale brown, light gray brown, etc.). Calcareous fossils constitute up to 20 per cent in the transitional facies. 
Other facies include siliceous nannofossil oozes, radiolarian muds, muddy and muddy siliceous (radiolarian) nannofossil oozes, siliceous muds, muddy siliceous (radiolarian) ashes, muddy nannofossil ashes, zeolitic (and radiolarian-bearing) calcareous claystone and mudstone, and chalk. The latter two deposits occur as interbeds between basalt units.

\section{Site 445}

All four subdivisions within the pelagic biogenic facies were recovered at Site 445 (Table 4). In order of decreasing abundance, the subfacies present are the biogenic calcareous, the transitional calcareous facies, the pelagic siliceous facies, and the transitional siliceous facies.

Calcareous facies contain nannofossil and foraminifer-nannofossil oozes, varying ash or clay content yielding the transitional facies. Lower in the section, the oozes become chalks, with similar consolidation of the transitional facies. Beginning in Core 59, the siliceous component becomes high, yielding siliceous nannofossil chalks, radiolarian nannofossil chalks, and other pelagic biogenic or transitional categories.

In general, foraminifers are abundant in the Pleistocene and Pliocene and decrease in numbers, size, and diversity from the Miocene to the middle Eocene.

\section{Site 446}

The pelagic biogenic facies is minimal at Site 446 (Table 4).

Pelagic biogenic calcareous deposits occur as calcareous oozes and/(or) chalk, whereas the siliceous biogenic facies is absent.

\section{Pyroclastic Facies}

The pyroclastic facies consists principally of volcanic ash, with sporadic and minor quantities of lapillae and bombs. The ash may occur as laminae or thin beds in a major lithology, or as a lithologic component in another lithofacies. Table 5 shows the distribution of pyroclastic materials at each site, according to mode of occurrence. Table 6 is a summary of the distribution of ash by sediment age time slices, showing the principal periods of explosive volcanism in the Shikoku Basin and the Daito Ridge-and-Basin province.

\section{Shikoku Basin}

The pyroclastic sediments of Shikoku Basin sites consist of ash, pumice, and altered ash. The ash is generally well-sorted and sand-sized, sand-silt-sized, or silt-sized, but altered ash is clay-like material. Pumice occurs as lapillae or bombs up to $4 \mathrm{~cm}$ in diameter. Colors of ash beds include from light gray to black and pale brown to dark brown; altered ash may be yellowish brown, pink, reddish yellow, reddish brown, and reddish black. The ash is composed mostly of clear glass (rhyolitic?), but a black, opaque basaltic glass is prominent between 91 and 165 meters (late Miocene) in Hole 444A.

The laminae or beds may be distinctly layered, with sharp contacts above and below, or they may be part of a normal, fining-upward graded sequence. Sharp basal
TABLE 5

Distribution of Pyroclastic Sediments

\begin{tabular}{cccc}
\hline Core & $\begin{array}{c}\text { As Distinct Beds } \\
\text { or Laminae }\end{array}$ & $\begin{array}{c}\text { As a Common } \\
\text { Constituent }\end{array}$ & $\begin{array}{c}\text { As a Rare } \\
\text { Constituent }\end{array}$ \\
\hline Site $\mathbf{4 4 2}$ & & &
\end{tabular}

Site $\mathbf{4 4 2}$

$\begin{array}{rrrr}1 & X & X & \\ 2 & X & X & \\ 3 & & X & \\ 4 & & X & \\ 5 & & X & \\ 6 & & \\ 7 & & X & \\ 8 & X & & \\ 9 & X & X & X \\ 10 & & & \\ 11 & & & \\ 12 & X & & \\ 13 & & X & \\ 14 & & & \\ 15 & & & X \\ 16 & & & \\ 17 & & & \\ 18 & & & \\ 19 & X & & \\ 20 & & & \\ 21 & & & \\ 22 & & & \\ 23 & & & \\ 24 & & & \\ 25 & & & \end{array}$

$\mathrm{X}$
$\mathrm{X}$
$\mathrm{X}$
$\mathrm{X}$

Site 443

\begin{tabular}{|c|c|c|c|}
\hline 1 & X & X & \\
\hline 2 & $X$ & $X$ & \\
\hline 3 & $X$ & $X$ & \\
\hline 4 & $X$ & X & \\
\hline 5 & X & X & \\
\hline 6 & & & $\mathrm{X}$ \\
\hline 7 & & & $\mathrm{X}$ \\
\hline 8 & $X$ & & $X$ \\
\hline 9 & & X & \\
\hline 10 & & $X$ & \\
\hline 11 & $X$ & $\mathrm{X}$ & \\
\hline 12 & & & $X$ \\
\hline 13 & & & \\
\hline 14 & & $X$ & \\
\hline 15 & & $X$ & \\
\hline 16 & & X & \\
\hline 17 & $X$ & X & \\
\hline 18 & X & $\mathrm{X}$ & \\
\hline 19 & & $\mathrm{X}$ & \\
\hline & & & \\
\hline 21 & & & \\
\hline 22 & & X & \\
\hline 23 & & X & \\
\hline 24 & & $\mathrm{X}$ & \\
\hline 25 & & & \\
\hline 26 & & & \\
\hline 27 & & & \\
\hline 28 & & & \\
\hline 29 & & & \\
\hline 30 & & & \\
\hline
\end{tabular}


TABLE 5 - Continued

\begin{tabular}{cccc}
\hline Core & $\begin{array}{c}\text { As Distinct Beds } \\
\text { or Laminae }\end{array}$ & $\begin{array}{c}\text { As a Common } \\
\text { Constituent }\end{array}$ & $\begin{array}{c}\text { As a Rare } \\
\text { Constituent }\end{array}$ \\
\hline
\end{tabular}

Site 443

$\begin{array}{ll}31 & \text { X } \\ 32 & \text { X? } \\ 33 & \text { X? } \\ 34 & \text { X? } \\ 35 & \\ 36 & \\ 37 & \\ 38 & \\ 39 & \text { X } \\ 40 & \text { X } \\ 41 & \text { X } \\ 42 & \text { X } \\ 43 & \text { X } \\ 44 & \text { X } \\ 45 & \text { X } \\ 46 & \text { X } \\ 47 & \text { X } \\ 48 & \text { X } \\ 49 & \text { X }\end{array}$

Site 444

\begin{tabular}{|c|c|c|}
\hline 1 & & $\mathrm{X}$ \\
\hline 2 & & $\mathrm{X}$ \\
\hline 3 & & \\
\hline 4 & $\mathrm{X}$ & $\mathrm{X}$ \\
\hline 5 & & $\mathrm{X}$ \\
\hline 6 & & \\
\hline 7 & $\mathrm{X}$ & \\
\hline 8 & & \\
\hline 9 & & $\mathrm{X}$ \\
\hline $10, \mathrm{~A} 1$ & X & $\mathrm{X}$ \\
\hline A2 & $\mathrm{X}$ & $X$ \\
\hline 3 & $\mathrm{X}$ & $\mathrm{X}$ \\
\hline 4 & & \\
\hline 5 & & \\
\hline 6 & & $\mathrm{X}$ \\
\hline 7 & & $\mathrm{X}$ \\
\hline 8 & & \\
\hline 9 & & X \\
\hline 10 & X & $\mathrm{X}$ \\
\hline 11 & $\mathrm{X}$ & $\mathrm{X}$ \\
\hline 12 & & $\mathrm{X}$ \\
\hline $\begin{array}{l}13 \\
14\end{array}$ & $x$ & $\mathrm{x}$ \\
\hline 15 & $\mathrm{X}$ & $\mathrm{X}$ \\
\hline 16 & $\mathrm{X}$ & $\mathrm{X}$ \\
\hline 21 & X & X \\
\hline 22 & $\mathrm{X}$ & X \\
\hline 23 & & \\
\hline
\end{tabular}

Site $\mathbf{4 4 5}$

\begin{tabular}{rrr}
1 & $\mathrm{X}$ & $\mathrm{X}$ \\
2 & $\mathrm{X}$ & $\mathrm{X}$ \\
3 & & $\mathrm{X}$ \\
4 & & $\mathrm{X}$ \\
5 & & $\mathrm{X}$ \\
6 & & \\
7 & & \\
8 & $\mathrm{X}$ & \\
10 & $\mathrm{X}$ & \\
11 & & \\
\hline
\end{tabular}

TABLE 5 - Continued

\begin{tabular}{cccc}
\hline As Distinct Beds & As a Common & As a Rare \\
or Laminae & Constituent & \begin{tabular}{c} 
Constituent \\
\hline
\end{tabular}
\end{tabular}

\section{Site $\mathbf{4 4 5}$}

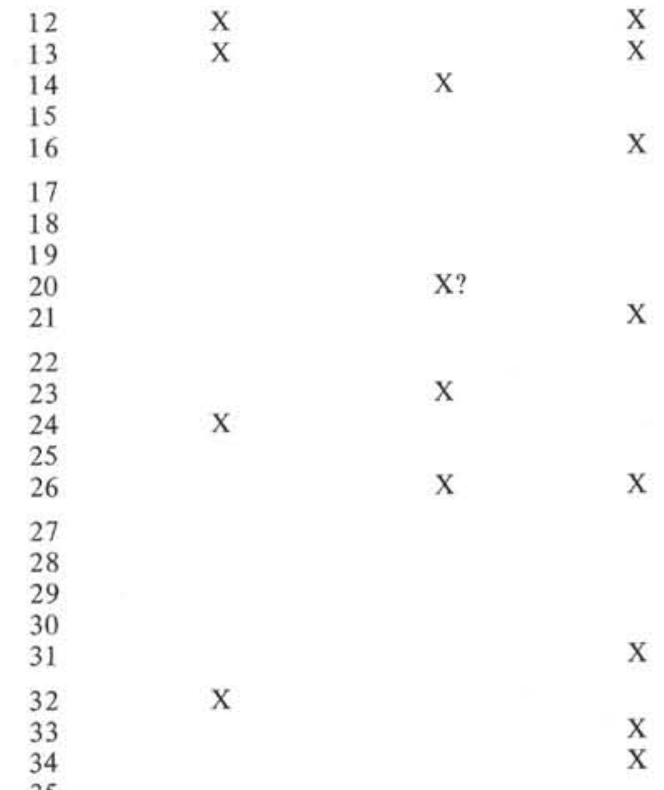

X

$\mathrm{X}$

X

$\mathrm{X}$

X

X

$\mathrm{X}$

$\mathrm{X}$

X

X

$\mathrm{X}$
$\mathrm{X}$

$\mathrm{X}$
$\mathrm{X}$
$\mathrm{X}$

$\mathrm{X}$
$\mathrm{X}$

$\mathrm{X}$

$\mathrm{X}$

X

X

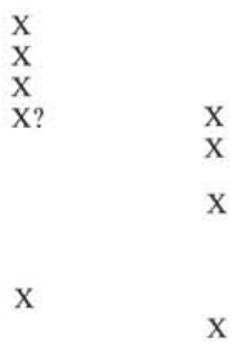


TABLE 5 - Continued

\begin{tabular}{cccc}
\hline Core & $\begin{array}{c}\text { As Distinct Beds } \\
\text { or Laminae }\end{array}$ & $\begin{array}{c}\text { As a Common } \\
\text { Constituent }\end{array}$ & $\begin{array}{c}\text { As a Rare } \\
\text { Constituent }\end{array}$ \\
\hline
\end{tabular}

\section{Site 445}

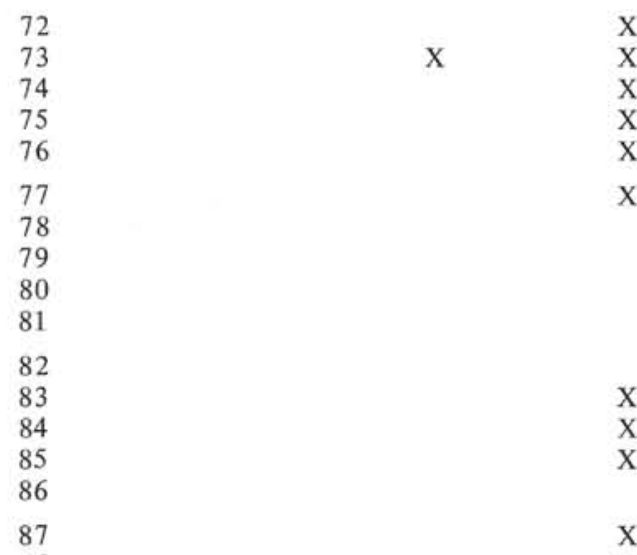

(No reported pyroclastics in cores 88-94)

Site 446

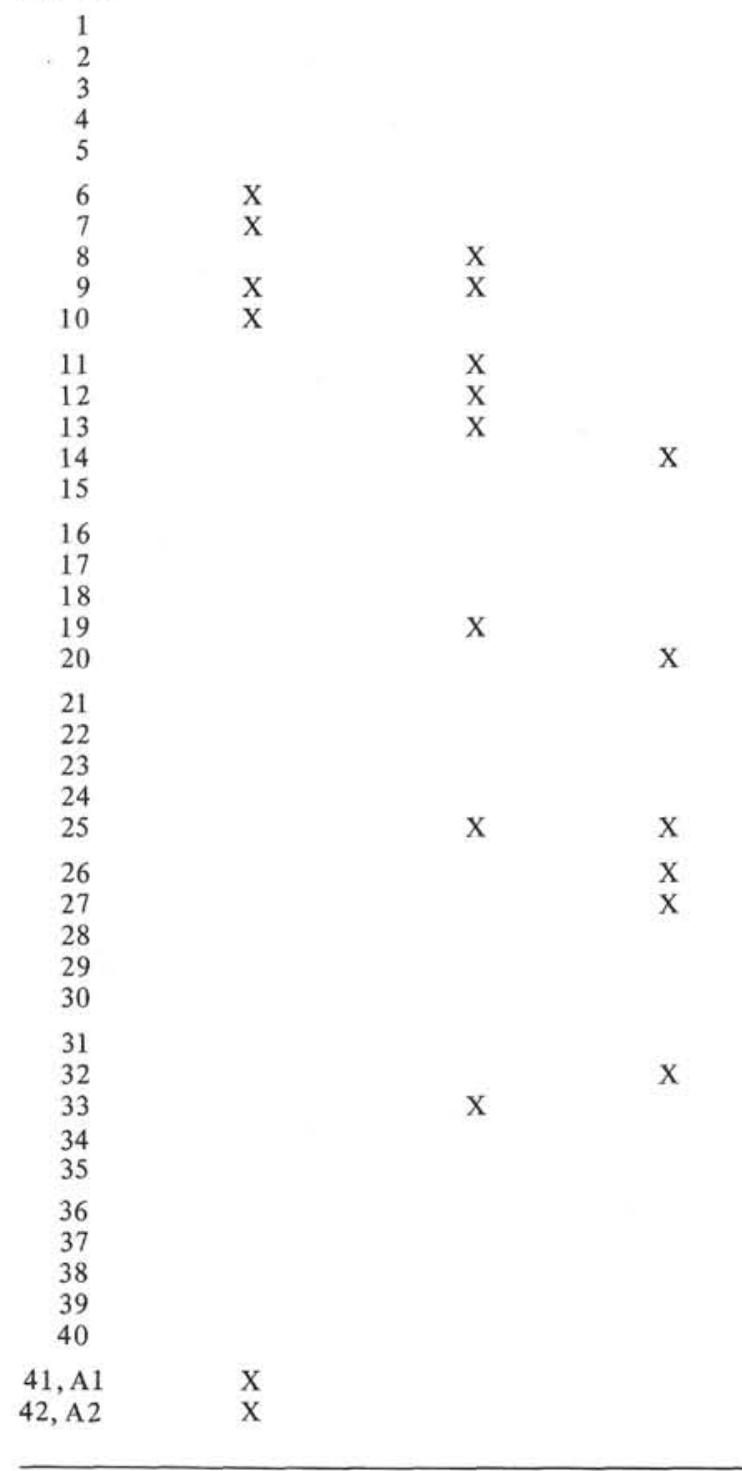

TABLE 5 - Continued

\begin{tabular}{|c|c|c|c|}
\hline Core & $\begin{array}{l}\text { As Distinct Beds } \\
\text { or Laminae }\end{array}$ & $\begin{array}{c}\text { As a Common } \\
\text { Constituent }\end{array}$ & $\begin{array}{c}\text { As a Rare } \\
\text { Constituent }\end{array}$ \\
\hline
\end{tabular}

\section{Site $\mathbf{4 4 6}$}

\begin{tabular}{ccc}
43, A3 & X & \\
A6 & & X \\
9 & & X \\
10 & $X$ & $X$ \\
12 & & \\
13 & & \\
14 & $X$ & \\
16 & $X$ & \\
17 & & \\
18 & & \\
19 & & \\
22 & & $X$ \\
23 & & \\
24 & & $X$ \\
25 & & \\
26 & & \\
27 & & \\
28 & & \\
\hline
\end{tabular}

contacts are not common. Mild to intense bioturbation is common and is intense enough in some cases to have destroyed the laminae. Bioturbation occurs frequently at the top of the graded sequences.

The pyroclastics occur principally within mud-mudstone and clay-claystone sequences in the Shikoku Basin. In the lower sections at each site, the sequence may be: mudstone-claystone, pyroclastic, calcareous biogenic; or mudstone-claystone, pyroclastic, siliceous biogenic. Altered ash overlies a pelagic clay (with manganese nodules, and zeolites) at the base of Hole 442B.

The wide vertical and lateral distribution of glass as a component of a mudstone or claystone lithofacies, and the discrete ash beds composed almost entirely of volcanic glass suggest that the pyroclastics in the Shikoku Basin have two origins: laminae and well-defined ash beds are the direct result of explosive volcanism from relatively nearby volcanoes; the ash as a component is probably resedimented, along with the sediments in which it is contained, or in some cases it may be from a very distant source. In the latter case, aerially or aquatically transported ash could have drifted into the basin and become incorporated into the sediment column, diluted by local hemipelagic sediments.

The basaltic ash in the upper Miocene at Site 444 is significant. The tephra layers at Site 442 likely were derived from the Japanese Islands, while those at Sites 443 and 444 were derived from a nearby, low-silica volcanic source.

The principal explosive volcanic events affecting Site 442 were in the Pleistocene ( $0-1.6 \mathrm{Ma})$ and in the middle Miocene (13-15 Ma). The principal explosive volcanic events affecting Sites 443 and 444 were in the Pleistocene, Pliocene (1.6-5 Ma), late Miocene (5-10.5 Ma), late middle Miocene (10.5-12 Ma), and early middle Miocene (14-16 Ma). The Pleistocene events appear to be most frequent and most intensive, judging from the 
TABLE 6

Correlation of Volcanic Events

\begin{tabular}{|c|c|c|c|c|c|c|c|c|c|c|}
\hline & Site & 442 & Site & 443 & Site & 444 & Site & 445 & Site & 446 \\
\hline Age & $\begin{array}{c}\text { Cores with } \\
\text { Ash in } \\
\text { Layers }\end{array}$ & $\begin{array}{l}\text { Cores with } \\
\text { Abundant } \\
\text { Admixed } \\
\text { Ash }\end{array}$ & $\begin{array}{c}\text { Cores with } \\
\text { Ash in } \\
\text { Layers }\end{array}$ & $\begin{array}{l}\text { Cores with } \\
\text { Abundant } \\
\text { Admixed } \\
\text { Ash }\end{array}$ & $\begin{array}{c}\text { Cores with } \\
\text { Ash in } \\
\text { Layers }\end{array}$ & $\begin{array}{l}\text { Cores with } \\
\text { Abundant } \\
\text { Admixed } \\
\text { Ash }\end{array}$ & $\begin{array}{l}\text { Cores with } \\
\text { Ash in } \\
\text { Layers }\end{array}$ & $\begin{array}{l}\text { Cores with } \\
\text { Abundant } \\
\text { Admixed } \\
\text { Ash }\end{array}$ & $\begin{array}{c}\text { Cores with } \\
\text { Ash in } \\
\text { Layers }\end{array}$ & $\begin{array}{c}\text { Cores with } \\
\text { Abundant } \\
\text { Admixed } \\
\text { Ash }\end{array}$ \\
\hline Pleistocene & 5 & 9 & 7 & 8 & 1 & 4 & 1 & 2 & missing & - \\
\hline Pliocene & 1 & 1 & 2 & 6 & 2 & 2 & 2 & 3 & $\begin{array}{l}\text { missing } \\
\text { or } 0\end{array}$ & - \\
\hline Late Miocene & 0 & 0 & $1(0 ?)$ & 3 & 2 & 5 & 1 & 3 & - & - \\
\hline Late Middle Miocene & 0 & 0 & $3(4 ?)$ & $?$ & 5 & 6 & 0 & 0 & - & - \\
\hline Mid Middle Miocene & $0(1 ?)$ & 0 & 0 & 0 & 0 ? & $?$ & 0 & 0 & 2 (age?) & 1 (age?) \\
\hline $\begin{array}{l}\text { Early Middle Miocene } \\
\text { Early Miocene }\end{array}$ & $4(3 ?)$ & $\begin{array}{l}0 \\
-\end{array}$ & 11 & 10 & 2 & 2 & 1 ? (age?) & 0 & 2 & 4 \\
\hline Late Oligocene & - & - & - & - & - & - & 0 & 2 & 0 ? & $\begin{array}{c}0 \text { ? (not } \\
\text { identified?) }\end{array}$ \\
\hline Middle Oligocene & - & - & - & - & - & - & 0 & 0 & 0 ? & $\begin{array}{c}0 \text { ? (not } \\
\text { identified?) }\end{array}$ \\
\hline Middle to early Oligocene & - & - & - & - & - & - & 3 & 2 & $0 ?$ & $0 ?$ \\
\hline Late Eocene & - & - & - & - & - & - & 2 & $3(4 ?)$ & $0 ?$ & $0 ?$ \\
\hline Middle Eocene & - & - & - & - & - & - & 0 & 2 & 4 & 5 \\
\hline Early Eocene & - & - & - & - & - & - & - & - & $4(3 ?)$ & 3 \\
\hline
\end{tabular}

number of cores which contain more than one ash layer and the number of cores which contain ash as a prominent lithologic component. Events of the early middle Miocene, apparently associated with intrusion of basaltic sills and extrusion of sea-floor basaltic flows, are also conspicuous. The arc supplying pyroclastics to the Shikoku Basin from the east appears to have been continuously active during the Neogene, except possibly for a period from 14 to $12 \mathrm{Ma}$. (The exception may be an artifact of questionable biostratigraphic determinations in this interval.)

\section{Daito Ridge and Basin}

The pyroclastics at Sites 445 and 446 are much less abundant than at Shikoku Basin sites. They consist of sand- and silt-sized glass, except where ash has been altered to clay. Colors are less varied than in the Shikoku Basin: light gray to black, with bluish gray, olive gray, greenish gray, pinkish gray, and grayish brown. Only the acidic (rhyolitic?), clear glass is present.

The ash occurs as laminae or as fining upward, graded beds, some with sharp or even scoured basal contacts. The ash in Hole 446A, Cores 12 and 13, is crossbedded. Bioturbation is not common. Slump structures are present where pyroclastics are part of a slumped sedimentary sequence, but such occurrences are rare.

At Site 445, pyroclastics occur within calcareous biogenic sequences, such as calcareous biogenic, volcanic, calcareous biogenic-repeatedly alternating. In several sections calcareous biogenic facies alternate with siliceous biogenic and volcanic-ash facies. Claystone is part of the sequence calcareous biogenic, volcanic, claystone, calcareous biogenic in a short interval (549-609 $\mathrm{m}$ ) in the upper Eocene. Volcanics are conspicuously absent in the thick resedimented middle-Eocene sequence, except as resedimented pebbles, fragments, or grains of transported volcanic debris.

At Site 446, the pyroclastics occur as part of the hemipelagic facies, either in clay-claystone or mud-mudstone sequences. We observed only one example of vol- canic ash as a prominent lithologic component in a resedimented conglomerate, sandstone, mudstone sequence. Claystone, volcanic, calcareous biogenic sequences are rare. Pyroclastics as ash beds are most common as interbeds between basalt flows, or as part of a basalt, claystone, mudstone, volcanic, basalt sequence.

The only prominent expressions of explosive volcanism at Site $\mathbf{4 4 5}$ are in the upper Miocene to Pleistocene, near the middle/lower Oligocene boundary, and in the upper Eocene. (Drilling stopped before reaching the early middle Eocene.) At Site 446, there is some indication of early-Miocene volcanism, and possibly some in the middle Miocene, in sections whose age is in doubt. The late Eocene-early Oligocene episode was not recorded in the sediments, possibly because of a missing section. The prominent volcanism associated with basalt flows is of early-and middle-Eocene age.

\section{Summary}

For a summary of this discussion of lithofacies, the reader is referred to a companion paper in this volume by Curtis and Echols. They have categorized the dominant facies sequences in each basin according to time and region.

\section{Northern Shikoku Basin}

Late Pleistocene

Pelagic biogenic (calcareous and siliceous), hemipelagic, pyroclastic

Early Pleistocene and Hemipelagic mudstone Pliocene

Pliocene and

Late Miocene

Late Miocene and

Middle Miocene

Middle Miocene and Early Miocene
Hemipelagic mudstone, resedimented sandstone

Hemipelagic mudstones

Pyroclastics 


\section{Eastern Shikoku Basin}

Pleistocene

and Pliocene

Late Miocene

Middle Miocene

Early Miocene

Western Shikoku Basin

Pleistocene,

Pliocene,

late Miocene

Middle Miocene

Early Miocene
Hemipelagic mudstones, minor pyroclastics

Hemipelagic mudstones, pyroclastics

Resedimented sandstones, pelagic biogenic sediments, pyroclastics

Pelagic clays

Hemipelagic mudstones, possibly volcaniclastic clays in the Pliocene

Hemipelagic mudstones, pyroclastics

Pelagic clays, pyroclastics

\section{SPECIAL TOPICS}

The following summarizes results of detailed studies of the Leg 58 sediments, or information pertaining to the lithofacies already described. The reader is also referred to specific chapters in this volume for further information.

\section{Physical Properties 9}

Sediments recovered by deep-sea drilling in the Shikoku Basin and Daito Ridge and Basin area vary considerably in composition, grain size, and texture. This variability is directly reflected in the physical properties of the sediments. The lithofacies established for Leg 58 sediments provide a convenient framework in which to examine the physical properties. Physical properties by depth for each site are presented in Figures 2-6, and for the various facies discussed in Figures 7-18.

\section{Resedimented Clastic Lithofacies}

The compositionally and texturally most varied lithofacies is the resedimented clastic lithofacies, represented by mudstones, sandstones, and conglomerates at Site 445 between 600 and 888 meters, and by mudstones between 363 and 504 meters at Site 446. Systematic variations with depth for the mudstones at Site 446 are shown in Figure 6. Sonic velocity increases from 1.5 to 2.0 $\mathrm{km} / \mathrm{s}$ downhole; water content decreases; porosity decreases; and wet-bulk density increases. Thermal conductivity and grain density show no apparent variation with depth. The porosity-depth and wet-bulk-density-depth relationships derived for pelagic clay and terrigenous clay (Hamilton, 1976) adequately describe the variations with depth for the resedimented clastic sediments at Site 446.

Down-hole variations for Site 445, however, are not similar to those at Site 446, or to the empirical relationships of Hamilton (1976). Variations of physical proper-

\footnotetext{
${ }^{9}$ By David Fountain, shipboard physical-properties specialist.
}

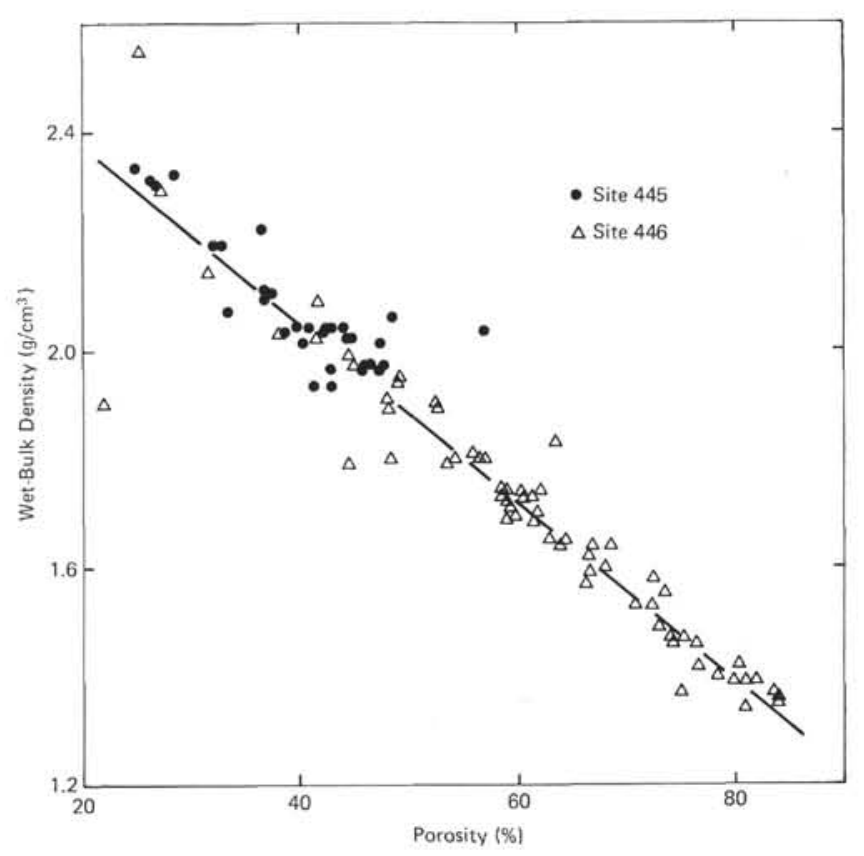

Figure 7. Wet-bulk density versus porosity for samples of the resedimented clastic lithofacies. Hemipelagic muds are plotted at the high-porosity end. Regression parameters are given in Table 8.

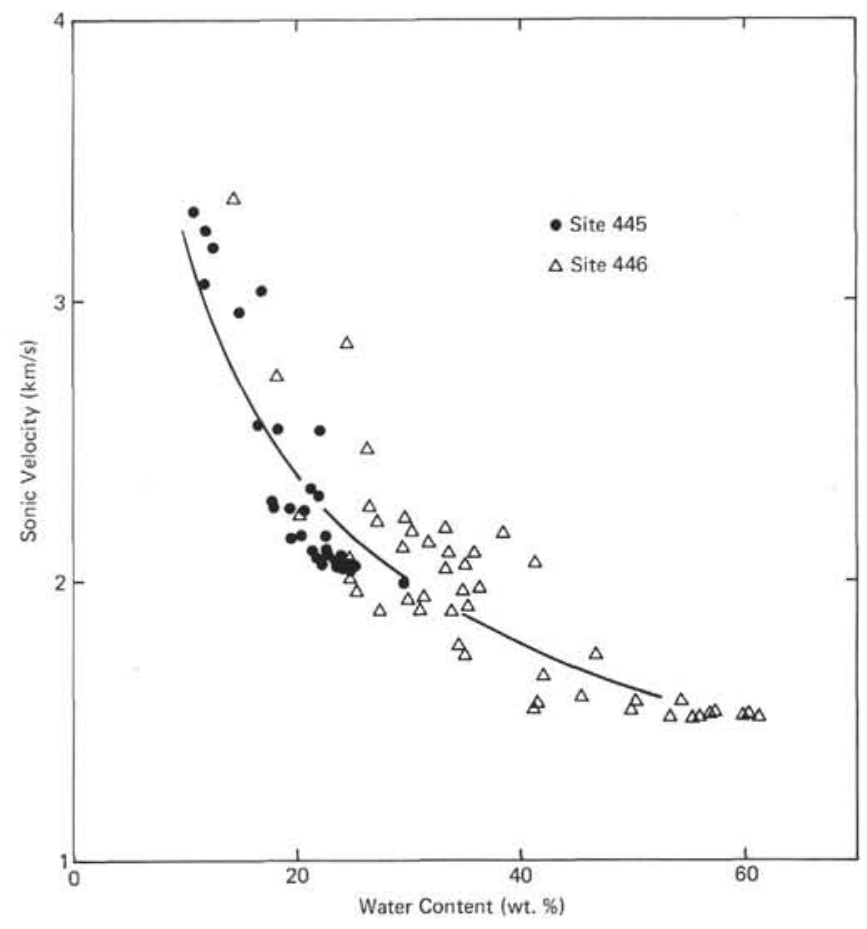

Figure 8. Sonic velocity versus water content for samples of the resedimented clastic lithofacies. Hemipelagic muds are plotted at the high-water-content end. Regression parameters are given in Table 8.

ties for the resedimented clastic lithofacies at Site 445 are shown in Figure 5. There is very little systematic change in any property between depths of 660 meters 


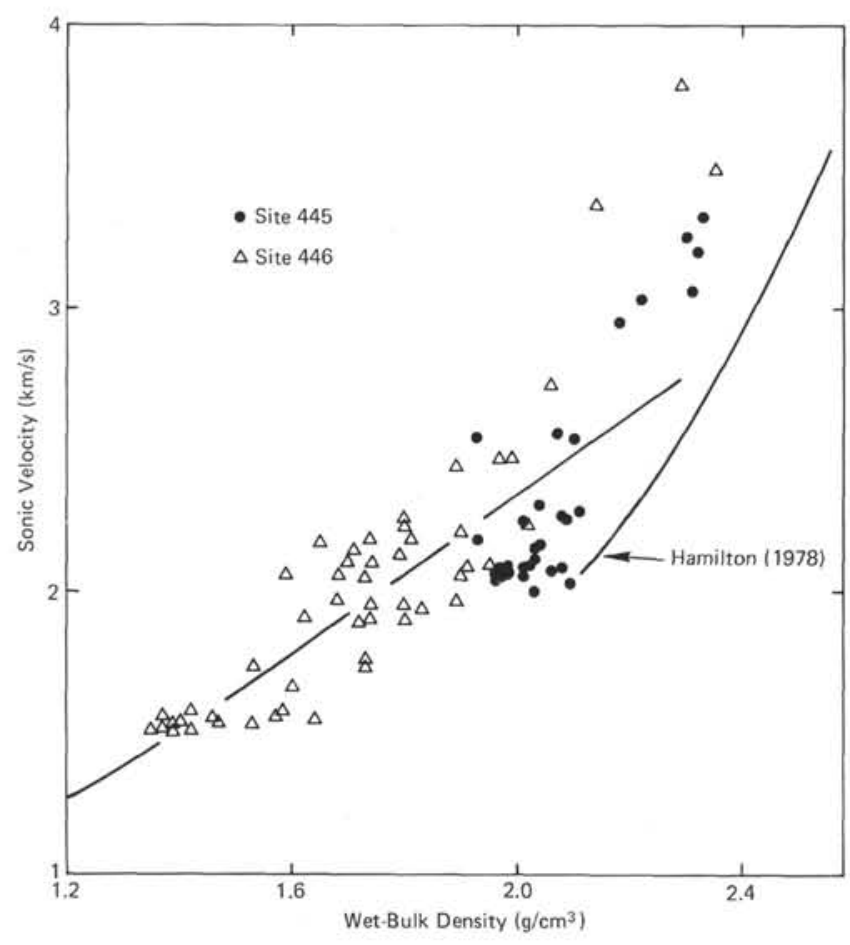

Figure 9. Sonic velocity versus wet-bulk density for samples of the resedimented clastic lithofacies. Hemipelagic muds are included at the low-density end. Also shown are the empirical relationship for shales ( $\mathrm{Ha}$ milton, 1978) and the best fit derived in this study. Regression parameters are given in Table 8.

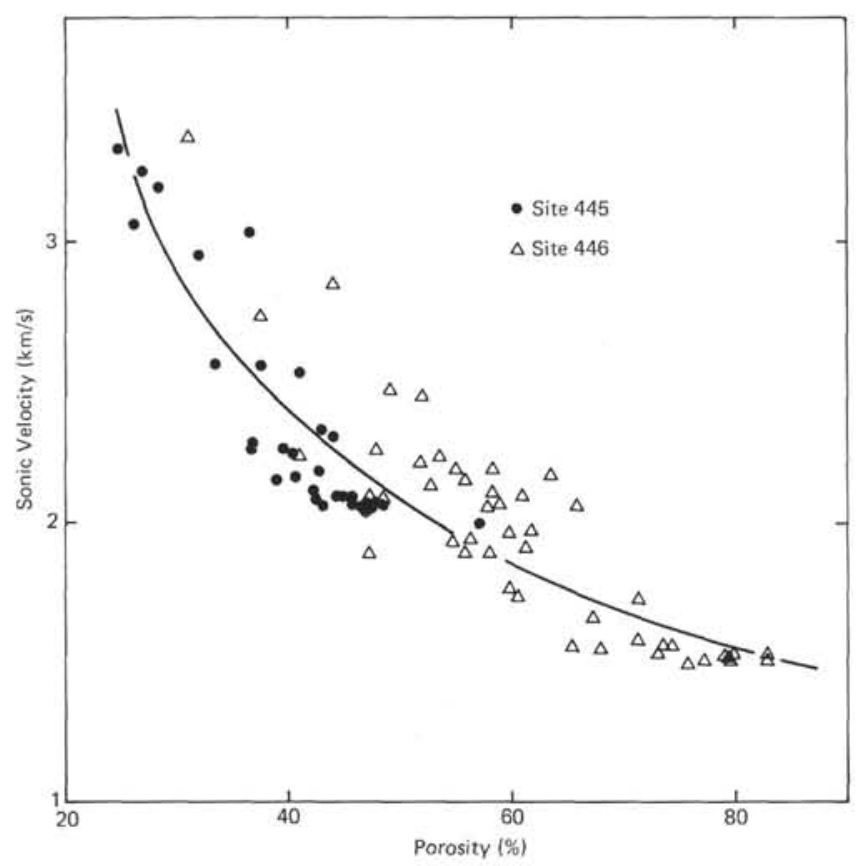

Figure 10. Sonic velocity versus porosity for samples of the resedimented clastic lithofacies. Hemipelagic muds are included for values of high porosity.

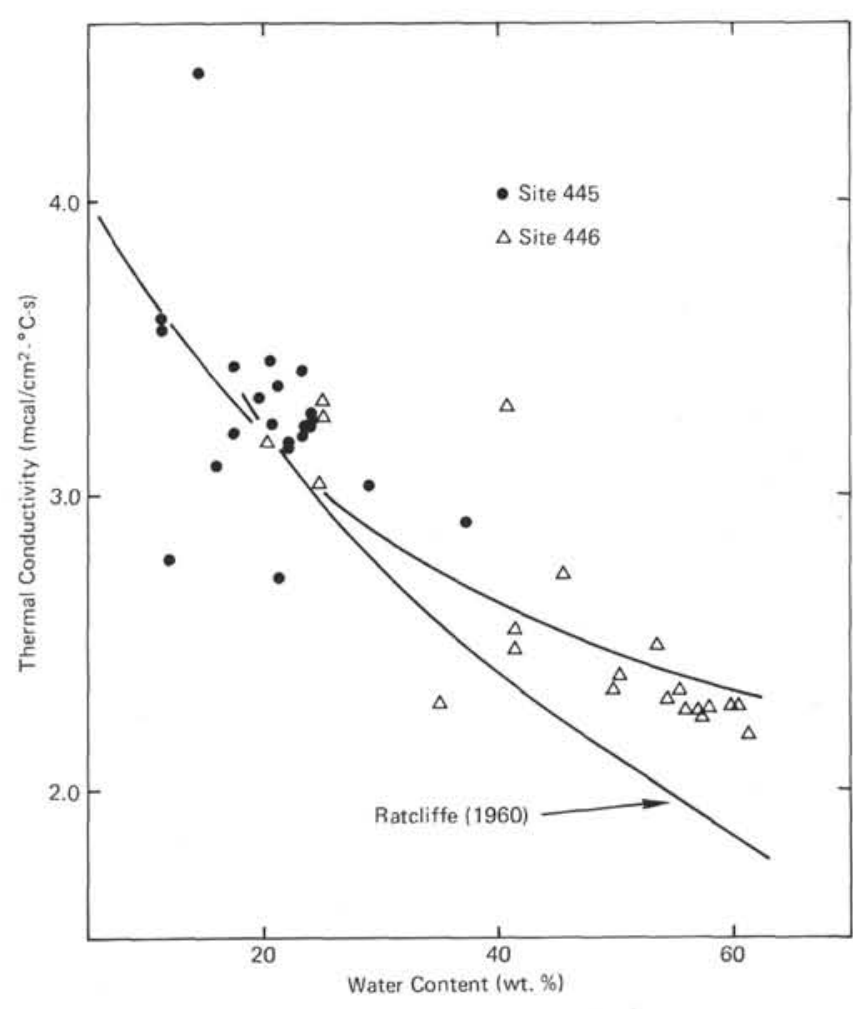

Figure 11. Thermal conductivity versus water content for samples of the resedimented clastic lithofacies. Hemipelagic muds are included for high values of water content. Also shown are relationships established by Ratcliffe (1960) and in this study. Regression parameters are given in Table 8.

and 800 meters. Below 800 meters, wet-bulk density increases, sonic velocity increases, porosity decreases, and water content decreases. Thermal conductivity and grain density show only minor down-hole variations.

Down-hole variations for the resedimented clastic lithofacies can be understood best by examining the variations in porosity of the studied samples. The averages and standard deviations of physical properties of the samples are tabulated in Table 7. The lithofacies is divided into mudstones, sandstones, and conglomerates. At Site 445 , the sandstones are below the mudstones, and the conglomerates are below the sandstones. Porosity is least in the coarse-grained conglomerates, and greatest in the fine-grained mudstones, as demonstrated by Hamilton (1974). The decrease of porosity down-hole, therefore, reflects the general increase in grain size down-hole.

All other physical properties are dependent on porosity. Wet-bulk density is inversely proportional to porosity, as demonstrated by the excellent linear fit in Figure 7 , and the high negative correlation coefficient (Table 8). Hemipelagic mudstones from Site 446 are included in Figure 7 to define the large-porosity portion of the relationship. The regression parameters are given in Table 8. The intercept of the line is $2.722 \mathrm{~g} / \mathrm{cm}^{3}$, 


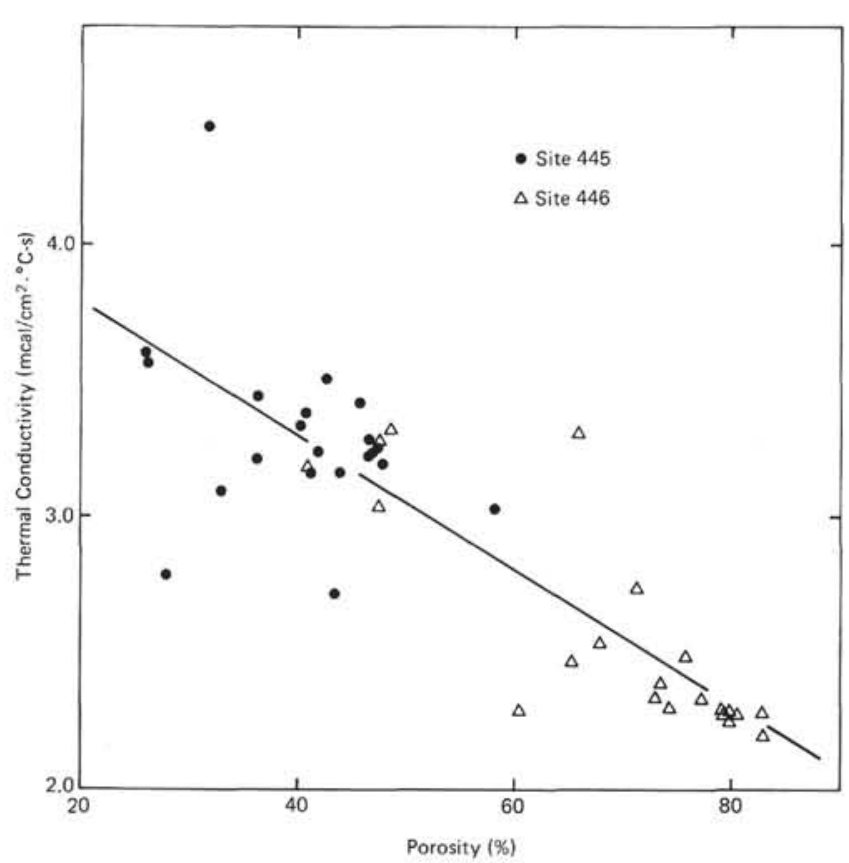

Figure 12. Thermal conductivity versus porosity for samples of the resedimented clastic lithofacies. Hemipelagic muds are included at the high-porosity end of curve. Regression parameters are given in Table 8.

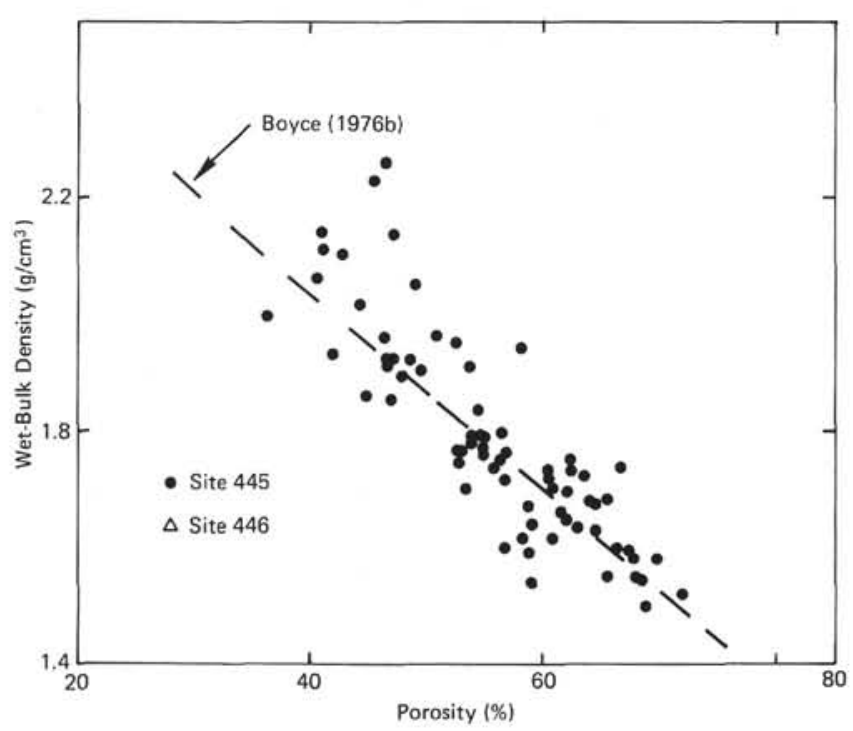

Figure 13. Wet-bulk density versus porosity for samples of the carbonate lithofacies. The dashed line is a theoretical relationship from Boyce (1976b).

which would be the density of a non-porous material of the composition of the samples plotted in Figure 7. This value is within the range of measured grain densities for the resedimented clastic lithofacies samples (Table 7), suggesting that most of these samples are similar enough in composition to have nearly the same grain density. Mineralogical differences, therefore, should be a much less important control on physical properties than porosity.

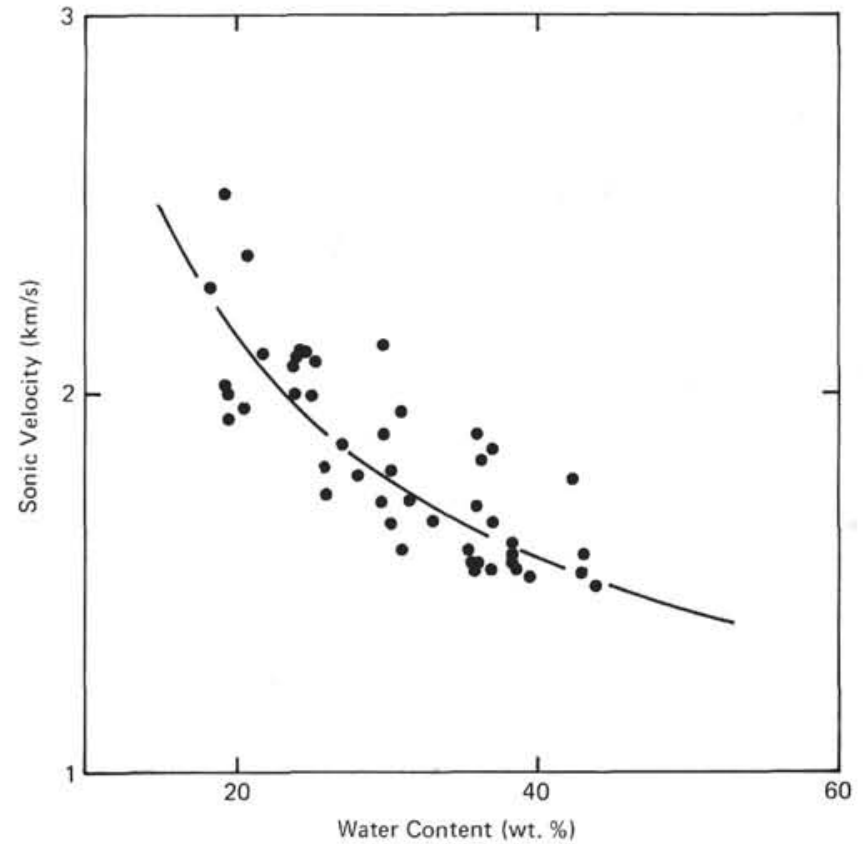

Figure 14. Sonic velocity versus water content for samples of the carbonate lithofacies. Regression parameters given in Table 10.

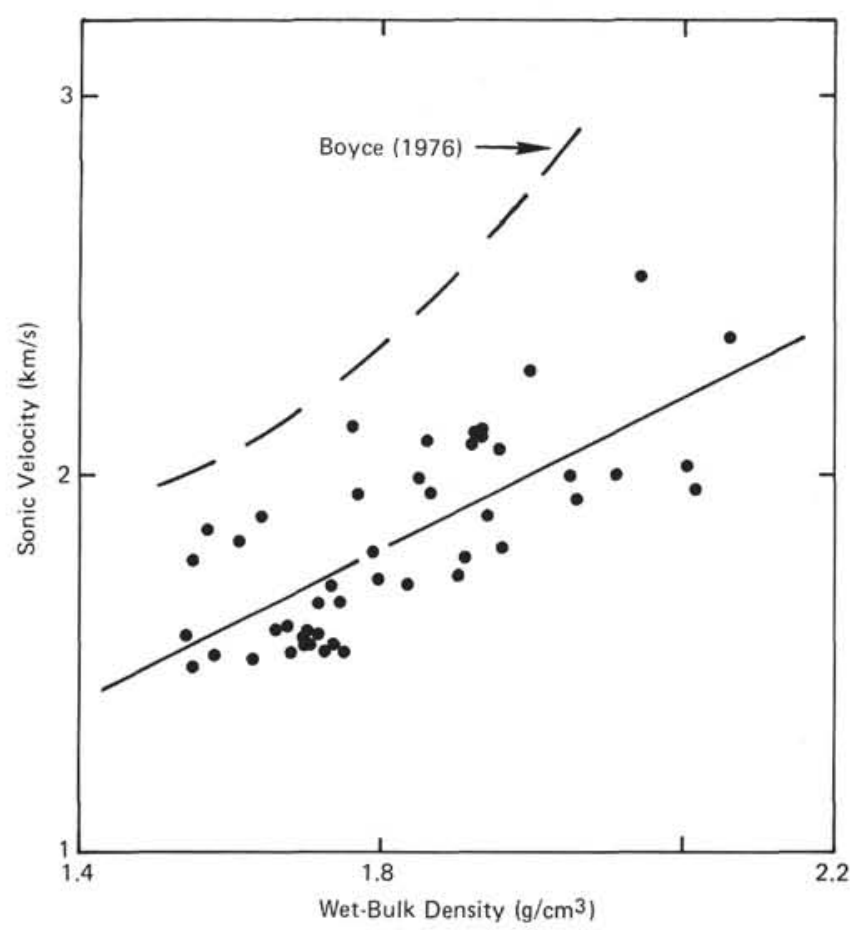

Figure 15. Sonic velocity versus wet-bulk density for samples of the carbonate lithofacies. Also shown are the theoretical relationship of Boyce (1976b) and the relationship derived in this study. Regression parameters are given in Table 10.

Figures 8,9 , and 10 show the dependence of sonic velocity on water content, wet-bulk density, and porosity, respectively. Data for hemipelagic mudstone from Site 446 is also plotted in these diagrams. Because grain 


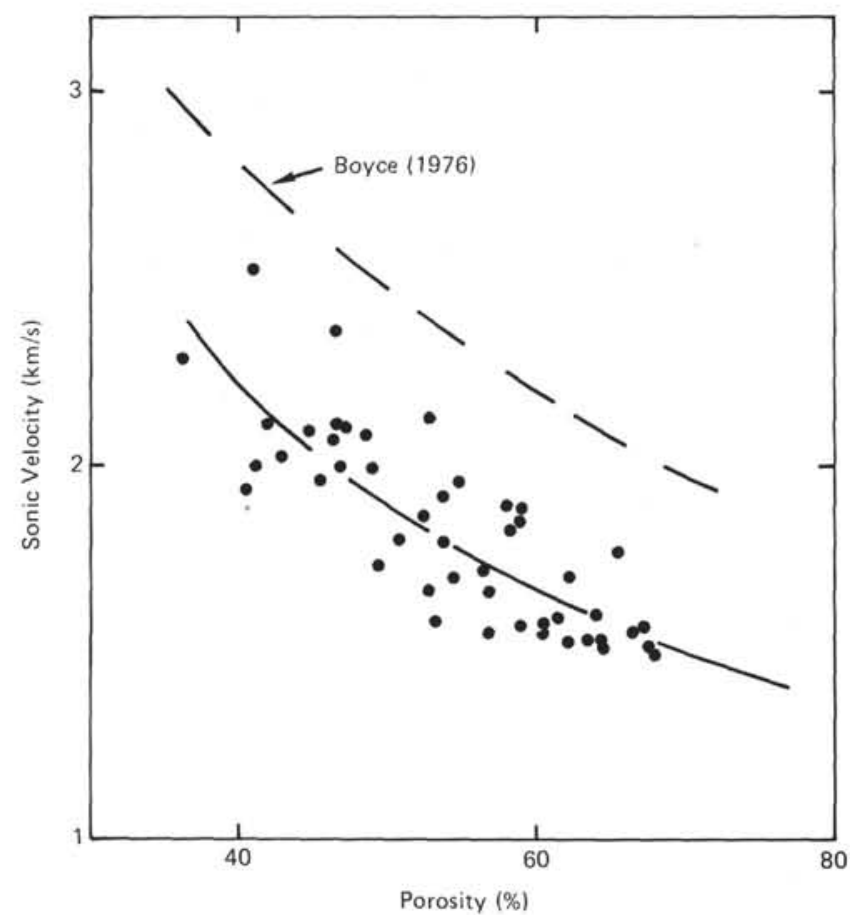

Figure 16. Sonic velocity versus porosity for samples of the carbonate lithofacies. Also shown are the theoretical relationship of Boyce (1976b) and the relationship derived in this study. Regression parameters are given in Table 10.

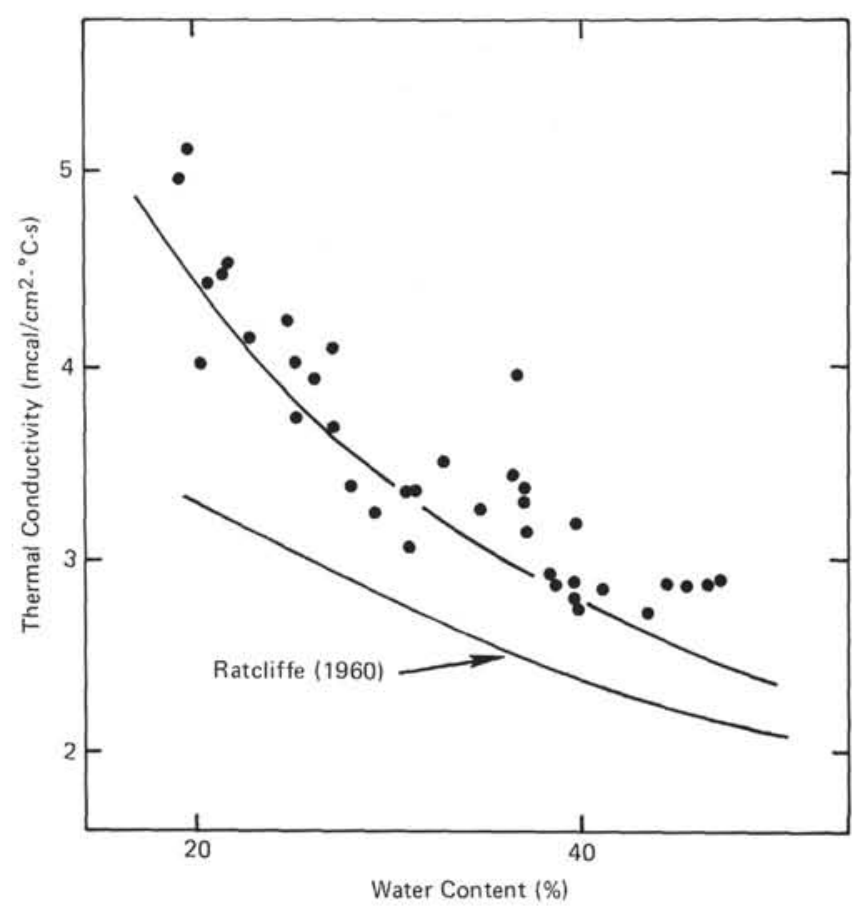

Figure 17. Thermal conductivity versus water content for samples of the carbonate lithofacies. Also shown are the relationships derived by Ratcliffe (1960) and in this study. Regression parameters are given in $\mathrm{Ta}$ ble 10.

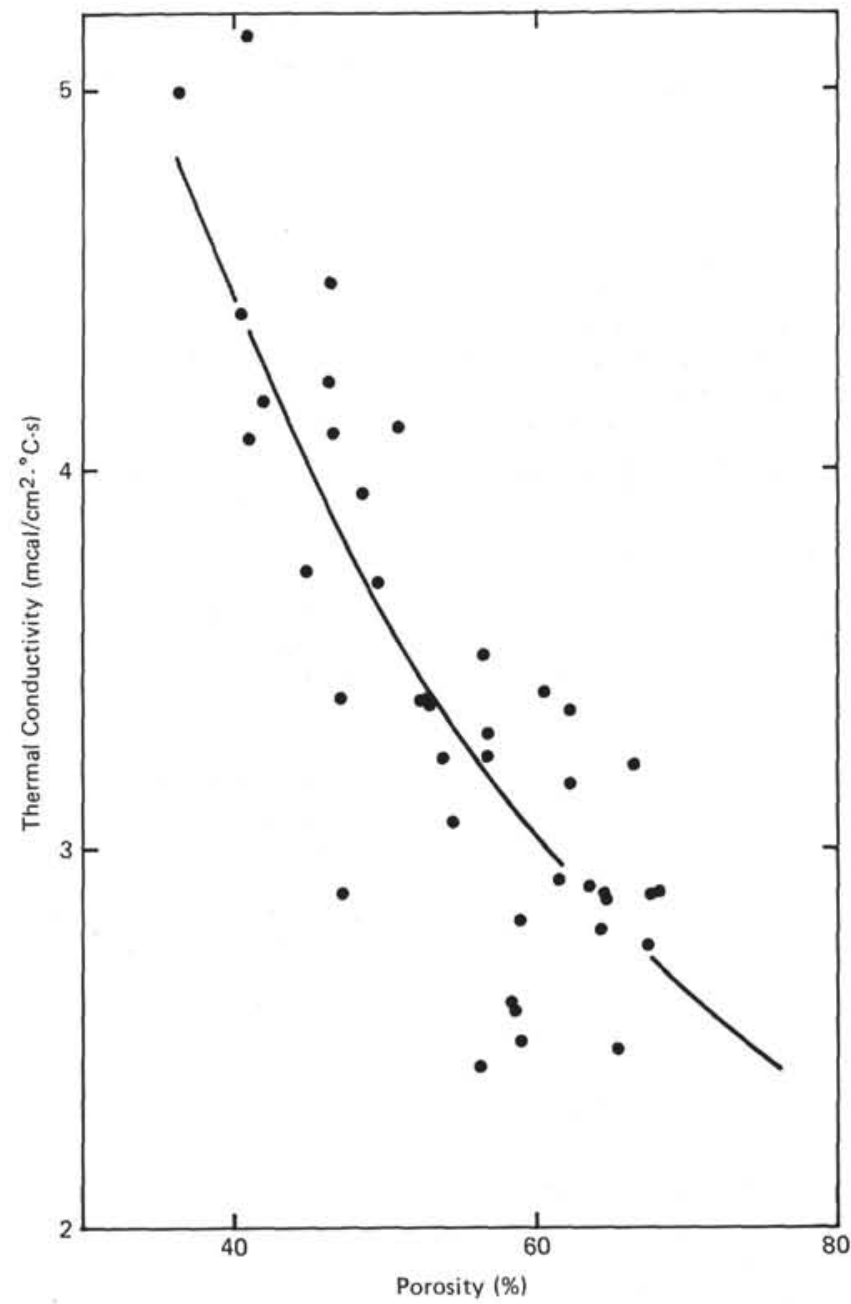

Figure 18. Thermal conductivity versus porosity for samples of the carbonate facies. Regression parameters are given in Table 10.

density can be regarded as constant, both water content and wet-bulk density are dependent on porosity. The relationships displayed in Figures 8 and 9, therefore, are consequences of the porosity dependence established in Figure 10. These relationships can be either linear or exponential. Regression parameters for these fits are given in Table 7. Also shown in Figure 9 is the velocity-density relationship of Hamilton (1978) for shales. The curve predicts velocities too large for given densities of samples of the resedimented clastic lithofacies.

Figures 11 and 12 show the dependence of thermal conductivity on water content and porosity, respectively. Thermal conductivity is inversely proportional to water content, as demonstrated by Ratcliffe (1960), but the curve does not follow Ratcliffe's empirical relationship for high-water-content values. Linear or power laws can be fit to the thermal-conductivity data. The regression parameters for these fits are given in Table 8 .

Water content, wet-bulk density, sonic velocity, and thermal conductivity are all related to sediment porosity for the resedimented clastic lithofacies. The down-hole 
TABLE 7

Summary of Physical Properties of Resedimented Clastic Lithofacies, Sites 445 and $446^{\text {a }}$

\begin{tabular}{|c|c|c|c|c|c|c|c|c|c|c|c|c|c|}
\hline \multirow[b]{2}{*}{ Site } & \multirow[b]{2}{*}{ Lithology } & \multicolumn{2}{|c|}{$\begin{array}{c}\text { Porosity } \\
(\%)\end{array}$} & \multicolumn{2}{|c|}{$\begin{array}{l}\text { Water Content } \\
\text { (wt. \%) }\end{array}$} & \multicolumn{2}{|c|}{$\begin{array}{l}\text { Wet-Bulk } \\
\text { Density } \\
\left(\mathrm{g} / \mathrm{cm}^{3}\right)\end{array}$} & \multicolumn{2}{|c|}{$\begin{array}{c}\text { Grain } \\
\text { Density } \\
\left(\mathrm{g} / \mathrm{cm}^{3}\right)\end{array}$} & \multicolumn{2}{|c|}{$\begin{array}{l}\text { Sonic } \\
\text { Velocity } \\
(\mathrm{km} / \mathrm{s})\end{array}$} & \multicolumn{2}{|c|}{$\begin{array}{c}\text { Thermal } \\
\text { Conductivity } \\
\left.\text { (mcal } / \mathrm{cm}^{2}{ }^{\circ} \mathrm{C}-\mathrm{s}\right)\end{array}$} \\
\hline & & Avg. & $\sigma$ & Avg. & $\sigma$ & Avg. & $\sigma$ & Avg. & $\sigma$ & Avg. & $\sigma$ & Avg. & $\sigma$ \\
\hline 445 & Mudstones & 43.58 & 4.821 & 21.710 & 2.643 & 2.008 & 0.050 & 2.801 & 0.182 & 2.149 & 0.129 & 3.195 & 0.160 \\
\hline 445 & Sandstones & 33.808 & 6.080 & 16.040 & 4.028 & 2.135 & 0.154 & 2.710 & 0.102 & 2.691 & 0.494 & 4.208 & 1.706 \\
\hline 445 & Conglomerates & 26.170 & 0.226 & 11.355 & 0.106 & 2.305 & 0.003 & 2.770 & 0.00 & 3.153 & 0.132 & 2.799 & 0.402 \\
\hline 446 & Mudstones & 56.980 & 9.907 & 32.995 & 8.166 & 1.764 & 0.158 & 2.785 & 0.092 & 2.074 & 0.390 & 2.799 & 0.402 \\
\hline
\end{tabular}

${ }^{\mathrm{a}}$ See also Table 8 .

$\sigma=$ standard deviation.

TABLE 8

Regression Parameters for Physical-Property Relationships, Resedimented Clastic ${ }^{a}$ and Hemipelagic Mudstone ${ }^{b}$ Lithofacies

\begin{tabular}{|c|c|c|c|c|c|c|c|}
\hline \multirow[b]{2}{*}{$x$} & \multirow[b]{2}{*}{$y$} & \multicolumn{3}{|c|}{$y=m x+b$} & \multicolumn{3}{|c|}{$y=k x^{m}$} \\
\hline & & $m$ & $b$ & $r^{*}$ & $k$ & $m$ & $r^{*}$ \\
\hline Porosity & Wet-bulk density & -0.0167 & 2.722 & -0.978 & - & - & - \\
\hline Water content & Sonic velocity & -0.0268 & 2.918 & -0.814 & 8.557 & -0.427 & -0.899 \\
\hline Wet-bulk density & Sonic velocity & 1.3943 & -0.454 & 0.820 & 1.030 & 1.163 & 0.848 \\
\hline Porosity & Sonic velocity & -0.0253 & 3.437 & -0.854 & 24.708 & -0.632 & -0.904 \\
\hline Porosity & Thermal conductivity & -0.0246 & 4.271 & -0.840 & 15.789 & -0.430 & -0.825 \\
\hline Water content & Thermal conductivity & -0.0270 & 3.814 & -0.848 & 7.766 & -0.293 & -0.850 \\
\hline
\end{tabular}

\footnotetext{
${ }_{b}^{\mathrm{a}}$ See also Table 7.

$\mathrm{b}_{\text {See also Table } 11 .}$.

$*_{r}=$ correlation coefficient.
}

variations in physical properties for the lithofacies are therefore best understood by the down-hole decrease in porosity, which is at least partly controlled by grain size (Hamilton, 1974).

\section{Resedimented and Pelagic Biogenic Carbonate Lithofacies}

Table 9 summarizes the averages and standard deviations of physical properties for both the resedimented carbonate lithofacies and the pelagic biogenic carbonate lithofacies. Because the average grain densities and calcium-carbonate contents are so similar for samples from each lithofacies, the two will be considered together.

Table 9 shows that the physical properties of the resedimented lithofacies consistently differ from the properties of the pelagic biogenic lithofacies. Both lithofacies occur at Site 445 , where the pelagic carbonates occur above the resedimented carbonate lithofacies. Inspection of Figure 6 shows that there are systematic down-hole changes in physical properties which cause the discrepancy in average physical properties for the two lithofacies. Systematic down-hole variations in the carbonate sediments include an increase in wet-bulk density, sonic velocity, and thermal conductivity, and a decrease in porosity and water content. Most changes are large and occur between the sea floor and the 500 -meter level. Sonic velocity increases from 1.7 to about $2.0 \mathrm{~km} / \mathrm{s}$; thermal conductivity increases from 2.7 to $4.5 \mathrm{mcal} / \mathrm{cm}^{2}-{ }^{\circ} \mathrm{C}$-s; and water content decreases by 30 per cent. Down-hole variations are similar to those reported by van der Lingen and Packham (1975) for Leg 30 carbonates, and to those summarized by Hamilton (1976) and Scholle (1977). The porosity-depth and wetbulk-density-depth relationships derived by Hamilton (1976) adequately describe the down-hole variations of carbonates displayed in Figure 6.

Figure 13 shows the dependence of wet-bulk density on porosity. Also shown in Figure 13 is the theoretical relationship between wet-bulk density and porosity for a

TABLE 9

Summary of Physical Properties of the Pelagic Biogenic Carbonate and Resedimented Carbonate Lithofacies, Site $445^{\mathrm{a}}$

\begin{tabular}{|c|c|c|c|c|c|c|c|c|c|c|c|c|c|}
\hline \multirow[b]{2}{*}{ Site } & \multirow[b]{2}{*}{ Lithology } & \multicolumn{2}{|c|}{$\begin{array}{l}\text { Porosity } \\
(\%)\end{array}$} & \multicolumn{2}{|c|}{$\begin{array}{l}\text { Water } \\
\text { Content } \\
\text { (wt. \%) }\end{array}$} & \multicolumn{2}{|c|}{$\begin{array}{l}\text { Wet-Bulk } \\
\text { Density } \\
\left(\mathrm{g} / \mathrm{cm}^{3}\right)\end{array}$} & \multicolumn{2}{|c|}{$\begin{array}{l}\text { Grain } \\
\text { Density } \\
\left(\mathrm{g} / \mathrm{cm}^{3}\right)\end{array}$} & \multicolumn{2}{|c|}{$\begin{array}{l}\text { Sonic } \\
\text { Velocity } \\
(\mathrm{km} / \mathrm{s})\end{array}$} & \multicolumn{2}{|c|}{$\begin{array}{c}\text { Thermal } \\
\text { Conductivity } \\
\left(\mathrm{mcal} / \mathrm{cm}^{2}-^{\circ} \mathrm{C}-\mathrm{s}\right)\end{array}$} \\
\hline & & Avg. & $\sigma$ & Avg. & $\sigma$ & Avg. & $\sigma$ & Avg. & $\sigma$ & Avg. & $\sigma$ & A vg. & $\sigma$ \\
\hline 445 & Pelagic biogenic & 65.608 & 3.480 & 40.654 & 3.336 & 1.618 & 0.068 & 2.805 & 0.186 & 1.544 & 0.040 & 2.864 & 0.160 \\
\hline 445 & Resedimented & 53.032 & 7.267 & 29.582 & 6.500 & 1.831 & 0.176 & 2.763 & 0.214 & 1.883 & 0.256 & 3.524 & 0.696 \\
\hline
\end{tabular}

${ }^{\mathrm{a}}$ See also Table 10. 
porous solid with the grain density of calcite (e.g., Boyce, 1976b). The least-squares linear fit is indistinguishable from the theoretical curve and is not plotted. The regression parameters are given in Table 10. Wetbulk density is primarily controlled by porosity, but the scatter displayed in Figure 13 may indicate a secondary control, such as minor mineralogical differences among samples.

Properties such as sonic velocity and thermal conductivity are also related to porosity. Figures 14,15 , and 16 show the relationships between sonic velocity and water content, wet bulk density, and porosity, respectively. The dependence of velocity on wet-bulk density and water content is a reflection of the dependence of those two parameters on porosity. Also shown in Figures 15 and 16 are theoretical curves for porous sediments composed entirely of calcite (e.g., Boyce, 1976b). In both cases, a greater sonic velocity is predicted by theory. The samples from Site 445, however, have a significant amount of clay minerals, which would cause the discrepancy. There is also considerable scatter of data in Figures 14,15 , and 16 , which may be related to mineralogical variations or grain-size variations in the samples.

Thermal conductivity is inversely related to water content (Figure 17) as demonstrated by Ratcliffe (1960), and therefore is inversely related to porosity (Figure 18). Thermal conductivity values, however, are greater than Ratcliffe's curve predicts. The discrepancy is caused by the high thermal conductivity of calcareous sediments (e.g., Clark, 1966; Hyndman et al., 1974).

Porosity is the primary control of physical-property variations for the carbonate lithofacies samples. Grain size variations and mineralogical differences, however, are apparently responsible for the scatter in the data. The down-hole decrease in porosity is similar to that observed in thick sections of chalk (Scholle, 1977) and may be related to cementation involving pressure solution and local re-precipitation (e.g., Scholle, 1977).

\section{Hemipelagic Clay and Mudstone Lithofacies}

Hemipelagic clays are the dominant lithofacies at the Shikoku Basin sites, whereas the hemipelagic mudstone lithofacies appears in the upper part of the section at Site 446 in the Daito Basin. All hemipelagic lithofacies sections occur between the sea floor and 360 meters below the sea floor. Smectite and illite are the dominant

TABLE 10

Regression Parameters for Physical-Property Relationships, Resedimented Carbonate and Biogenic Pelagic Lithofacies ${ }^{\mathbf{a}}$

\begin{tabular}{|c|c|c|c|c|c|c|c|}
\hline \multirow[b]{2}{*}{$x$} & \multirow[b]{2}{*}{$y$} & \multicolumn{3}{|c|}{$y=m x+b$} & \multicolumn{3}{|c|}{$y=k x m$} \\
\hline & & $m$ & $b$ & $r^{\circ}$ & $k$ & $m$ & $\overrightarrow{r^{*}}$ \\
\hline Porosity & Wet-bulk density & -0.0182 & 2.797 & 0.846 & - & - & - \\
\hline Water content & Sonic velocity & -0.0280 & 2.678 & -0.819 & 8.173 & -0.445 & -0.833 \\
\hline Wet-bulk & & & & & & & \\
\hline density & Sonic velocity & 0.9822 & 0.035 & 0.743 & 1.011 & 0.979 & 0.746 \\
\hline Porosity & Sonic velocity & -0.0245 & 3.153 & -0.826 & 28.824 & -0.696 & -0.832 \\
\hline Porosity & Thermal & & & & & & \\
\hline & conductivity & -0.0626 & 6.839 & -0.826 & 139.242 & -0.934 & -0.832 \\
\hline Water content & $\begin{array}{l}\text { Thermal } \\
\text { conductivity }\end{array}$ & -0.0763 & 5.784 & -0.855 & 30.335 & -0.647 & -0.875 \\
\hline
\end{tabular}

clay minerals at the Shikoku Basin sites, and the hemipelagic mudstones at Site 446 are almost entirely smectite (Chamley, this volume). The averages for each physical property (Table 11) are very similar for all sites.

There are, however, subtle differences between the Shikoku Basin data and the Daito Basin data. This is demonstrated particularly by the greater average sonic velocity, grain density, water content, and porosity, and the slightly smaller average wet-bulk density at Site 446 . Because the depth of recovery is similar for all sites, the Daito Basin site differences must result from the smectite-dominated mineralogy.

In general, physical properties of the hemipelagic lithofacies show no systematic down-hole variations, or are nearly constant down-hole. Wet-bulk density, however, usually increases somewhat down-hole, and the trends are adequately described by the pelagic-clay or terrigenous-clay curves derived by Hamilton (1976). Either the pelagic-clay or the terrigenous-clay curves of Hamilton (1976) can describe the general decrease of porosity with depth within the hemipelagic sections.

The range of values of physical properties for the hemipelagic lithofacies is too small to use for studying relationships between the properties. Figures 7 through 12 , however, display the hemipelagic data for Site 446 at the small-density or large-porosity ends of the relationships plotted. Data from the Shikoku Basin sites would not differ appreciably from the relationships displayed in those figures. The velocity-density relationship established by Hamilton (1976) for marine silts, clays, and turbidites at the sea floor or between 0 and 500 meters depth adequately describes the velocity-density relationship for Leg 58 hemipelagic sediments.

Shear strength varies considerably in the hemipelagic lithofacies. The average shear strength of sediments from the hemipelagic lithofacies at Site 446 is greater than that for the hemipelagic sediments from the Shikoku Basin sites. (See site report chapters in this volume.) Site 446 sediments are smectite-rich in the upper eight cores and are 100 per cent smectite below that. Shikoku Basin hemipelagic sediments are composed of varying amounts of smectite, illite, and other minerals (see Chamley, this volume) and, in general, are small-shearstrength sediments. The mixture of different clay minerals in the Shikoku Basin hemipelagic sediments may cause the sediment to behave as a more-granular solid with little cohesion, whereas monomineralic smectite sediments may have great cohesive strength.

\section{Non-Biogenic Pelagic Lithofacies}

Samples for this lithofacies come from a thin interval (13 meters thick) at Site 442 . Table 12 summarizes the physical properties of this lithofacies. In general, the average values for the various properties are similar to those of the hemipelagic sediments. (See Table 11.) Average values of thermal conductivity, grain density, and wet-bulk density are slightly less than for most of the hemipelagic sediments. The larger values of shear strength (Figure 2) reflect the burial depth and the smectite mineralogy of this small interval. 
TABLE 11

Summary of Physical Properties of Hemipelagic Clay and Mudstone Lithofacies, Sites 442, 443, 444, $446^{\mathrm{a}}$

\begin{tabular}{|c|c|c|c|c|c|c|c|c|c|c|c|c|c|}
\hline \multirow[b]{2}{*}{ Site } & \multirow[b]{2}{*}{ Lithology } & \multicolumn{2}{|c|}{$\begin{array}{c}\text { Porosity } \\
(\%)\end{array}$} & \multicolumn{2}{|c|}{$\begin{array}{c}\text { Water } \\
\text { Content } \\
\text { (wt. \%) }\end{array}$} & \multicolumn{2}{|c|}{$\begin{array}{l}\text { Wet-Bulk } \\
\text { Density } \\
\left(\mathrm{g} / \mathrm{cm}^{3}\right)\end{array}$} & \multicolumn{2}{|c|}{$\begin{array}{l}\text { Grain } \\
\text { Density } \\
\left(\mathrm{g} / \mathrm{cm}^{3}\right)\end{array}$} & \multicolumn{2}{|c|}{$\begin{array}{l}\text { Sonic } \\
\text { Velocity } \\
(\mathrm{km} / \mathrm{s})\end{array}$} & \multicolumn{2}{|c|}{$\begin{array}{c}\text { Thermal } \\
\text { Conductivity } \\
\left(\mathrm{mcal} / \mathrm{cm}-{ }^{\circ} \mathrm{C}-\mathrm{s}\right)\end{array}$} \\
\hline & & Avg. & $\sigma$ & Avg. & $\sigma$ & Avg. & $\sigma$ & Avg. & $\sigma$ & Avg. & $\sigma$ & Avg. & $\sigma$ \\
\hline 442 & Clays & 71.141 & 6.342 & 48.091 & 4.505 & 1.481 & 0.063 & 2.693 & 0.335 & 1.557 & 0.202 & 2.164 & 0.539 \\
\hline 443 & Clays & 71.777 & 3.333 & 48.072 & 3.038 & 1.494 & 0.053 & 2.764 & 0.232 & 1.552 & 0.078 & 2.315 & 0.288 \\
\hline 444 & Clays & 72.565 & 4.106 & 49.496 & 4.797 & 1.472 & 0.064 & 2.727 & 0.112 & 1.519 & 0.042 & 2.327 & 0.153 \\
\hline 446 & Muds & 75.156 & 8.528 & 52.585 & 8.389 & 1.445 & 0.106 & 2.835 & 0.198 & 1.539 & 0.059 & 2.277 & 0.132 \\
\hline
\end{tabular}

${ }^{\mathrm{a}}$ See also Table 8 .

TABLE 12

Summary of Physical Properties of Pelagic Non-biogenic and Pyroclastic Lithofacies, Site 442

\begin{tabular}{|c|c|c|c|c|c|c|c|c|c|c|c|c|c|}
\hline \multirow[b]{2}{*}{ Site } & \multirow[b]{2}{*}{ Lithology } & \multicolumn{2}{|c|}{$\begin{array}{c}\text { Porosity } \\
\text { (\%) }\end{array}$} & \multicolumn{2}{|c|}{$\begin{array}{l}\text { Water } \\
\text { Content } \\
\text { (wt. \%) }\end{array}$} & \multicolumn{2}{|c|}{$\begin{array}{l}\text { Wet-Bulk } \\
\text { Density } \\
\left(\mathrm{g} / \mathrm{cm}^{3}\right)\end{array}$} & \multicolumn{2}{|c|}{$\begin{array}{c}\text { Grain } \\
\text { Density } \\
\left(\mathrm{g} / \mathrm{cm}^{3}\right)\end{array}$} & \multicolumn{2}{|c|}{$\begin{array}{l}\text { Sonic } \\
\text { Velocity } \\
(\mathrm{km} / \mathrm{s})\end{array}$} & \multicolumn{2}{|c|}{$\begin{array}{c}\text { Thermal } \\
\text { Conductivity } \\
\left.\text { (mcal } / \mathrm{cm}^{\circ}{ }^{\circ} \mathrm{C}-\mathrm{s}\right)\end{array}$} \\
\hline & & Avg. & $\sigma$ & Avg. & $\sigma$ & Avg. & $\sigma$ & Avg. & $\sigma$ & Avg. & $\sigma$ & Avg. & $\sigma$ \\
\hline 442 & Pelagic non-biogenic & 72.905 & 4.685 & 51.048 & 5.378 & 1.433 & 0.063 & 2.610 & 0.178 & 1.581 & 0.023 & 1.941 & 0.588 \\
\hline 443 & Pyroclastic & 68.513 & 5.313 & 51.350 & 10.377 & 1.367 & 0.117 & 2.705 & 0.332 & 1.754 & 0.491 & 1.843 & 0.463 \\
\hline
\end{tabular}

\section{Pyroclastic Lithofacies}

A few samples from the pyroclastic lithofacies come from a thin interval (20 meters thick) at Site 442 . Properties within this lithofacies are variable, as indicated by large standard deviations tabulated in the summary (Table 12). Average sonic velocity is greater than the averages for hemipelagic sediments (Table 11). Thermal conductivity, wet-bulk density, grain density, and water content, however, are smaller than averages for the hemipelagic sediments (Table 11). The variability of properties for this lithofacies reflects the varying amount of volcanic ash in the sediment.

\section{Conclusions}

Physical properties of Leg 58 sediments and sedimentary rocks are directly related to sample porosity and composition. Properties within each lithofacies are directly related to down-hole variations in porosity. Mineralogical and grain-size variations within each lithofacies are minor influences on physical properties. The lithofacies, however, differ considerably in composition, texture, and grain size. Thus, the carbonate lithofacies is easily distinguished from the other lithofacies on the basis of various physical properties. The downhole variability in properties (Figures 2-6) is the result of overall changes in sediment composition and closure of pore space.

Site 445 is particularly interesting because drilling penetration was deep enough to allow study of downhole variations in thick sections of the pelagic biogenic carbonate and resedimented carbonate lithofacies and resedimented clastic lithofacies. In both the carbonate and clastic lithofacies, physical properties change systematically as pore space closes. Pore closure in the carbonates is probably related to diagenetic processes (e.g., van der Lingen and Packham, 1975; Scholle, 1977), whereas porosity loss in the resedimented clastic facies can be related to a general down-hole increase in grain size (e.g., Hamilton, 1974).

Sections of hemipelagic sediments within a few hundred meters of the sea floor (Sites 442, 443, 444, and 446) show neither the range of properties nor the magnitude of changes with depth that the compositionally and texturally varied sediments of Site 445 do. Although the clay mineralogy may vary at each site, there are no significant associated changes in the physical properties. Thick sections of hemipelagic sediments, however, will show substantial property changes downhole as pore space is reduced.

\section{Paleomagnetism of Sediments}

Approximately 925 minicores were sampled from the cores of Sites 442 through 446 for paleomagnetism studies. The results of the present work (see Kinoshita, this volume) are in agreement with other paleomagnetism results from the area.

Three significant results have been obtained. First, the paleolatitude obtained from Pleistocene sediments is smaller by about 10 degrees than the present value. This appears to result from distortion of the NRM inclination of the sediments by drilling and handling. Second, the present latitude of the Daito region is significantly greater than the paleolatitude during the Eocene. Therefore, the Daito region must have drifted northward since the Eocene by about $2000 \mathrm{~km}$. Assuming a constant rate of motion and due-north drift of the region, the rate of spreading is at least $5 \mathrm{~cm}$ per year. Third, although it is not clear whether the Daito region was in the northern or the southern hemisphere during the Eocene, the region seems to have crossed the equator about $45 \mathrm{Ma}$, although this is not definite. A similar argument is presented by Louden (1977) in a paleomagnetism 
study of sediment cores from the western Philippine Basin.

Measurement of NRM over a 15-meter interval of nannofossil-chalk cores from Site 445 revealed four magnetic-polarity transitions about $25 \mathrm{Ma}$.

Two of the four polarity transitions were rapid, and the polarity changed within 6000 years. The remaining transitions were slow, and the polarity switched over 25,000 to 30,000 years. The present results support the model of field reversal in which the main dipole field decays to a low value and then builds up in the opposite direction. The present data also show that the geomagnetic dipole moment of reversed polarity is less stable than that of normal polarity. Normal polarity lasted much longer than reversed polarity around $24 \mathrm{Ma}$. This supports the statistical argument presented by Wilson et al. (1972) and Dagley et al. (1974).

\section{Organic Geochemistry}

The Leg 58 sediments, in terms of organic geochemistry, are unusual in that they represent a system in which the post-depositional effects can be isolated (see Waples, this volume). The vast majority of the recovered sediments are either hemipelagic (Sites 442, 443, and 444) or pelagic (Sites 445 and 446), and the quantity of organic matter is consistently very low ( $<0.5 \%$ organic carbon). The organic matter probably arrived in the sediments in two ways: adsorbed on clay particles, or attached to the tests of microplankton. There is no evidence of any detrital organic debris within the sequences or organic-matter-rich layers.

The deposition of organic material appears to have been constant in intensity, chemical composition, and mode of transport. It seems apparent that any significant variations in the organic material preserved in the sediments are due to post-depositional processes.

In general for all sites, organic carbon and nitrogen decrease steadily in the first 50 to 200 meters, then remain constant at very low values throughout the lower part of the section. The decrease appears to be related to bacterial diagenesis of the organic material. This suggests that bacterial changes in this abyssal ecosystem occurs at much greater sub-bottom depths (up to 200 meters) and over much longer intervals (up to 5 m.y.) than has been previously accepted for such environments.

Several of the holes drilled on Leg 58 penetrated alternating layers of basalt and sediment. Recovery of the interbedded sediments was often poor, and only a few actual sediment/basalt contacts were recovered. At Site 444 , organic-geochemistry data were used to estimate the age of a sill. As Waples and Sloan (this volume) observe, a gradual decrease in organic carbon and nitrogen occurs with increasing sediment depth in all the Leg 58 sedimentary profiles. In a plot of organic carbon data versus depth at Site 444 (see fig. 1, Waples and Sloan, this volume), three features are apparent immediately. First, there is a steady decrease in organic carbon from the sediment/water interface to a depth of about 90 meters, below which organic carbon remains constant at about 0.06 per cent. Second, organic-carbon values in the first 10 meters below the sill are significant- ly greater than in the 150 meters immediately above the sill. Third, the organic-carbon contents of sediments more than 10 meters below the sill are similar to those in the sediments overlying the sill.

When an igneous sill or dike comes into contact with sediments in which organic diagenesis is not yet complete, the resulting pyrolysis of sedimented organic material may bring about a premature cessation of bacterial degradation of organic material. At Site 444, this pyrolysis has resulted in the preservation of greater concentrations of organic carbon in the pyrolyzed sediments. Comparison of the anomalous carbon contents with the normal carbon-diagenesis curve (fig. 3, Waples and Sloan, this volume) for non-pyrolyzed Site 444 sediments allowed estimation of the age of the basalt between 12.2 and $13.5 \mathrm{~m}$.y. If this approach is correct, then it also can be concluded that the basalt was intruded into unconsolidated sediments, rather than extruded at the sediment/water interface, because the sediments are $14.2 \mathrm{~m} . \mathrm{y}$. old.

Additional organic-geochemistry studies were aimed at gaining a better understanding of the early diagenetic history of sedimentary chlorophyll (see Baker and Lou$\mathrm{da}$, this volume). In this investigation, 19 core-samples from the Shikoku Basin and the Daito Ridge and Basin provinces were examined for products of chlorophyll diagenesis.

The paucity of chlorophyll derivatives in sediments sampled during Leg 58 reflects both the lack of organic-matter influx and the predominance of an oxidative mode of diagenesis. Tetrapyrrole pigments isolated from Leg 58 sediments indicate an early oxic depositional mode. Because these sediments were generated from low-productivity pelagic regions, are reworked, are high in carbonate, and contain abundant fecal organic matter, sedimentary chlorophyll was exposed to oxidation and, hence, removal from the fossil record.

\section{Paleoecology}

\section{Radiolarians}

Radiolarian material from Leg 58 generally is poorly preserved. (See also Sloan, this volume.) Due to the sparse radiolarian record, paleoecological interpretations are tentative.

The three sites drilled in the Shikoku Basin show similar radiolarian preservation and ecology. The Kuroshio Current is clearly the dominant factor influencing the ecology of the area. Near it, there is a larger tropical component; when it has lesser influence, cold-water species from the north and east are more abundant. When the Kuroshio meander is not present, colder waters from the east move over the area, causing the observed mixed death assemblage. Diatoms show this same mixed death assemblage, common fragments of the tropical diatom Ethmodiscus rex occurring with abundant Coscinodiscus marginatus, a cold-water species (L. Burckle, pers. comm.).

Sites 445 and 446 are characterized by poor radiolarian preservation throughout the sequence. Oligocene to middle-Miocene radiolarians occur at Site 445, and 
Miocene species occur at Site 446 . However, the relative lack of radiolarians in the Eocene at Sites 445 and 446 is likely due to mobilization of silica and the formation of chert.

Miocene radiolarians are believed to represent a midlatitude assemblage. Because of poor preservation, this may be more apparent than real. Cold-water species tend to be more robust than warm-water species, and they resist solution better. Because of selective dissolution of tropical species, the resulting Miocene assemblage appears more non-tropical than it may have been at the time of deposition. Eocene radiolarians (Sites 445 and 446) were rarely found, but are common where preserved. A typical tropical assemblage was found, but without other high-latitude studies of the Eocene this is difficult to interpret. The paleomagnetic data for these two sites also suggest an equatorial latitude during the Eocene. It is not known why the Pliocene sediments yielded no radiolarian fossils, but it is thought to be an effect of taphonomy and not ecology.

\section{Nannofossils}

Miocene to Quaternary calcareous nannofossils were observed at the three sites in the Shikoku Basin, whereaslower-Eocene to Quaternary assemblages were recovered at the two sites in the Daito Ridge and Basin province. (See also Okada, this volume.) Nannofossils are sporadic at all sites, except at Site 445, where abundant nannofossils occur continuously in most recovered cores.

\section{Foraminifers}

Foraminifers recovered from sites in the Shikoku Basin were rare and poorly preserved. (See also Echols, this volume.) At the three sites, the only assemblages identified with any confidence were in the Pleistocene (N.23, N.22) to the Pleistocene/Pliocene boundary (N.21), and even here the fauna is meager and shows much dissolution. Only the most heavily calcified, robust planktonic forms survived solution. No agedeterminate forms were encountered from the Pliocene to the middle Miocene. At 14 to 15 m.y., a tentative correlation of the three sites and a very speculative date is suggested.

At Site 442, the barren sequence through the Miocene is interrupted by the occurrence of replaced casts of what appear to be benthic foraminifers. This must be a local phenomenon; it was not observed in contemporaneous sediments at the other sites. The presence of these casts is not easily explained if at the time of deposition the area was below the CCD (which has been concluded). The benthic foraminifers, although also sporadic, indicate deep water. Marked reworking and displaced shallow-water assemblages were not seen in this basin.

In the Daito Ridge and Basin province, at both sites, post-Eocene deposits consist of pelagic sediments, whereas Eocene sediments are resedimented clastics. At both sites, redeposited Eocene larger shallow-water foraminifers were recovered. The fauna indicates a warm, shallow, carbonate environment and was no doubt resedimented from surrounding ridges.

\section{Dissolution of Foraminifers}

It is possible to use solution stages of the foraminifer assemblages to detect proximity to the lysocline and CCD (Figure 19). A lysocline based on a dissolving foraminifer assemblage would be the depth separating the well-preserved from the poorly preserved assemblages. The solution stages are defined and listed for cores of Leg 58 sites in Table 13.

\section{Rhodochrosite Replacement of Foraminifers}

Echols et al. (this volume) document an unusual replacement of foraminifer tests (?) by rhodochrosite.

At Hole $442 \mathrm{~A}$, Core 21 contains rare internal molds of what appear to be replaced foraminifers. In Core 22 they are fairly common, and in Cores 23 and 24 they are abundant and show an increase in morphological diversity. Under the light microscope, the shapes and diversity of forms suggest planktonic foraminifers. Although they are not identifiable to genus, the forms seem to be closely related to and morphologically resemble planktonic foraminifers. Chamber arrangements also suggestive of planktonic forms were detected.

Surface features revealed in SEM photographs show that replacement has occurred in rhombic crystals. A fragmented diatom on the surface of a foraminifer (?) and a coccolithid showing some overgrowth and nestled in the diatom were seen.

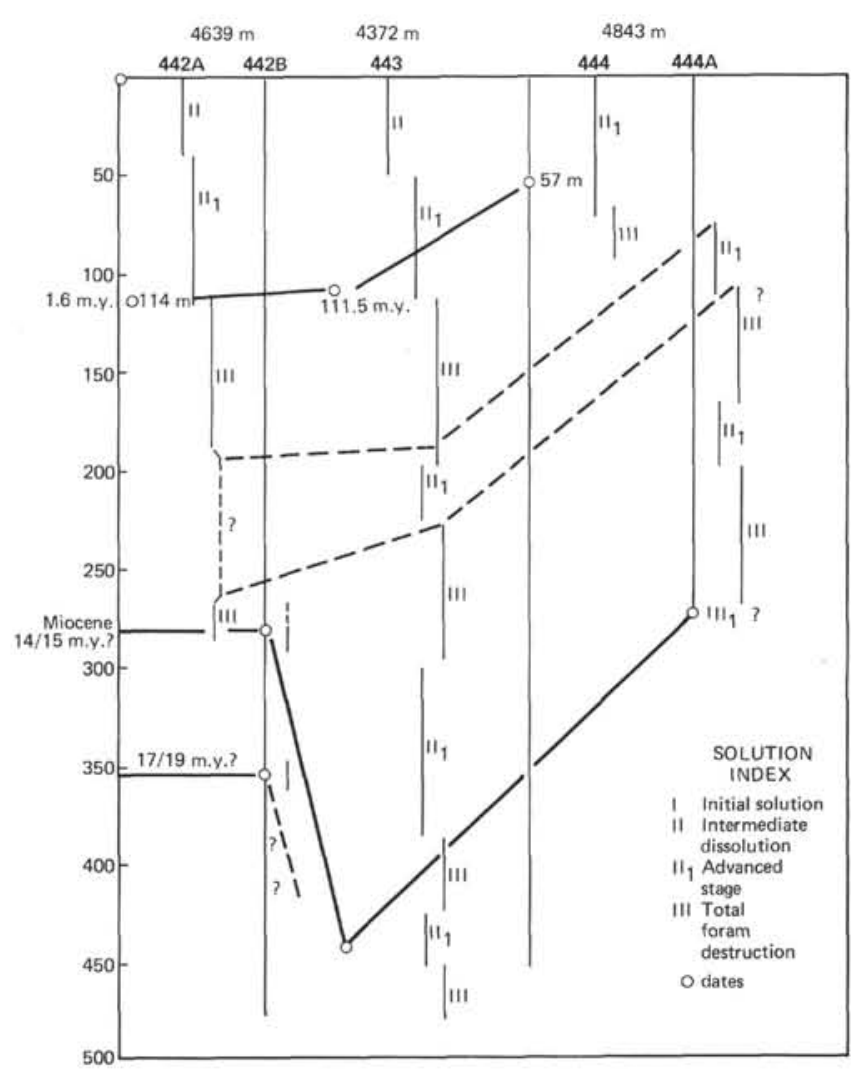

Figure 19. Solution profiles, Leg 58 Sites. 
TABLE 13

Foraminifer-Solution Profiles, Leg 58 Sites

Site 442 ( $4639 \mathrm{~m}$; below present CCD?). Throughout the section, the solution effects are obvious, and deposition was within zones designated as intermediate (II) and total dissolution (III). (See also Figure 19.)

\begin{tabular}{ccc}
\hline $\begin{array}{c}\text { Cores } \\
\text { (Hole 442A) }\end{array}$ & $\begin{array}{c}\text { Sub-bottom Depth of } \\
\text { Base of Core } \\
\text { (m) }\end{array}$ & Solution Stage \\
\hline $1-4$ & 38 & II \\
$5-12$ & 114 & III \\
$13-30$ & 285 & III \\
$? 21-28$ & $190-266$ & (?)
\end{tabular}

(Hole 442B)

$\begin{array}{lll}1 & 277 & \text { III(?) } \\ 1 & 286.5 & \text { III(?) } \\ 9 & 353 & \text { III(?) }\end{array}$

Site 443 ( $4372 \mathrm{~m}$; at or below present CCD?). This site displays the same pattern as Site 442 . The water depth of 4372 meters appears to be below the present CCD

\begin{tabular}{ccc}
\hline & $\begin{array}{c}\text { Sub-bottom Depth of } \\
\text { Base of Core } \\
(\mathrm{m})\end{array}$ & Solution Stage \\
Cores & 54.5 & II \\
$1-6$ & 115 & III \\
$6-12$ & 197 & III \\
$13-21$ & 222.5 & III \\
$22-25$ & 301.5 & III \\
$26-32$ & 387 & III \\
$33-41$ & 425 & III \\
$41-45$ & 453.5 & III \\
$46-48$ & 477.5 & II
\end{tabular}

Site 444 ( $4843 \mathrm{~m}$; below present CCD). The solution pattern is very similar to that at Sites 442 and 443

\begin{tabular}{|c|c|c|}
\hline $\begin{array}{c}\text { Cores } \\
(\text { Hole 444) }\end{array}$ & $\begin{array}{l}\text { Sub-bottom Depth of } \\
\text { Base of Core } \\
(\mathrm{m})\end{array}$ & Solution Stage \\
\hline $1-7$ & 66.5 & III \\
\hline $7-10$ & 95 & III \\
\hline \multicolumn{3}{|l|}{ (Hole 444A) } \\
\hline $1-3$ & 110.5 & III \\
\hline$? 6-9$ & 167.5 & III \\
\hline $10-12$ & 196 & III \\
\hline $13-22$ & 272.0 & III \\
\hline 23 & 278.0 & III(?) \\
\hline
\end{tabular}

Site 445 ( $3382 \mathrm{~m}$; above present CCD). No dissolution: the site was above the foraminifer lysocline throughout deposition. Rare and barren sections local (?). Rapid deposition masking fauna?

Site 446 (4980 m; below present CCD). Deposition throughout shows advanced foraminifer destruction. Ap parent total destruction in the Pleistocene and much of the Pliocene. Very rare foraminifer recovery (stage II, advanced) in a few cores in the Miocene.

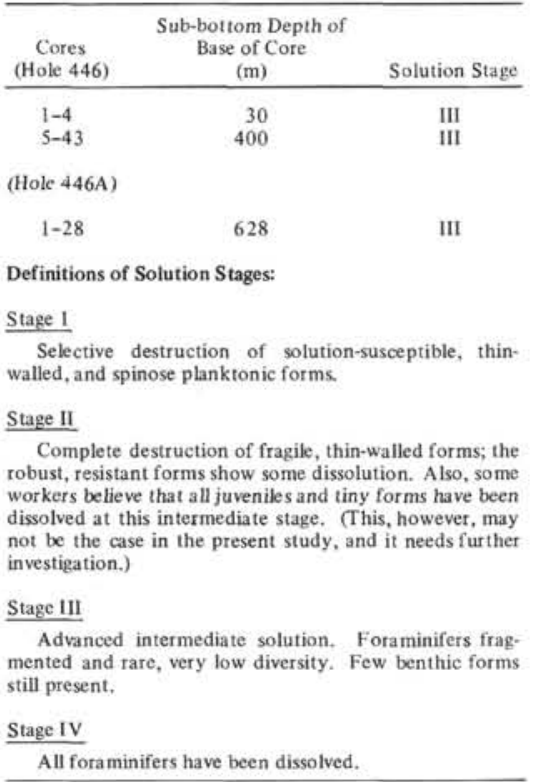

It is not possible to satisfactorily explain the occurrence of these replaced forms, but it should be observed that this may be a very local phenomenon, for they were not detected in any of the other studied foraminifer samples from other sites drilled on Leg 58 . The general appearance of the assemblage, the abundance, and the lack of evidence of transport indicate a replaced planktonic fauna that locally escaped obliteration by rapid burial and rapid replacement.

\section{Trace Fossils}

Three major lithofacies groups present in Leg 58 cores - terrigenous turbidites (resedimented clastic), biogenic ooze (pelagic biogenic), and pelagic clay (pelagic non-biogenic) - are certainly of deep-water origin, and each contains a diagnostic suite of bioturbation features. (See Ekdale, this volume.)

The hemipelagic and resedimented terrigenous facies occur in the upper parts of cores from Sites 442, 443, 444 , and 446 . The upper, fine-grained sub-units of the turbidites in Leg 58 cores typically are finely laminated and non-bioturbated through most of their thickness. However, some burrowing does occur in the uppermost sub-units of many sequences, which display no laminations, but common Chondrites. Middle-Eocene deposits at Site 445 typify this pattern. The well-defined burrowed horizons sometimes are only one or two centimeters thick, even though the entire turbidite may be more than half a meter thick. The Chondrites in these fine-grained sub-units typically are small. Branching is primarily horizontal or subhorizontal, suggesting that labile organic material (usable as food) was concentrated along laminations rather than distributed uniformly through the hemipelagic mud.

The pelagic biogenic facies, particularly the carbonates at Site 445 , contain the richest trace-fossil assemblages. Trace fossils characterizing the biogenic ooze facies include Chondrites, Planolites, Skolithos, and Zoophycos. This association is particularly well-preserved in upper-Miocene deposits at Site 445. These ichnogenera are superimposed on wholly bioturbated sediment, so they are thought to have been introduced below the mixed layer and in the transition zone of the sediment.

The pelagic brown-clay facies, exemplified in the lower part of Hole 442B, includes sediments deposited at or below the CCD beneath low-productivity regions of the oceans. Distinctive burrows preserved in pelagic clays in DSDP cores are less diverse than those in other facies, although the intensity of bioturbation is commonly just as high. The trace fossils characterizing brown abyssal clays in cores are dominated by Planolites.

An approximate bathymetric zonation of the three deep-sea ichnofacies would be, in order of increasing water depth: (1) the sharply defined bioturbated horizons of hemipelagic sediments containing Chondrites, (2) the Chondrites-Planolites-Zoophycos association of the biogenic ooze, and (3) the smeared Planolites of the pelagic brown clay. 


\section{Palynology}

A palynological study was made on samples from cores collected below 410 meters at Site 445 and between 86 and 365 meters at Site 446. (See Tokunaga, this volume.)

Pollen and spores generally are very rare in the limestone and calcareous rocks at Sites 445 and 446 . In contrast, pollen and spores in the middle-Eocene mudstone are common. The Oligocene sediments between 86 and 150 meters at Site 446 are composed of clay with ash, and they contain almost no pollen or spores. The middle-Eocene sediments below these are dark-gray claystone and muddy sandstone and contain many pollen grains and spores.

Among these pollen and spore assemblages of the middle Eocene at the two sites, Taxodiaceaepollenites, Sciadopityspollenites, and Sequoiapollenites indicate a temperate climate; Palmaepollenites, Ephedripites, and Zonocostites (Rhizophora) are subtropical and tropical elements, and Osmundacidites and Lygodioisporites generally are indicators of warm-temperate conditions.

\section{Tephra}

On the basis of petrographic characteristics, chemical composition, and paleontological age, tephra layers from the Shikoku Basin (Furata et al., this volume) are divided into the following groups: (1) layers of nonalkali rhyolitic tephra in the Pleistocene and Pliocene at Sites 442, 443, and 444, (2) layers of non-alkali rhyolitic tephra in the Miocene at Site 444, (3) layers of nonalkali tholeiitic basalt tephra in the Miocene at Sites 443 and 444, (4) layers of alkali rhyolitic tephra in the Miocene at Site 443, and (5) layers of alkali basaltic tephra in the Miocene at Site 444.

It is clear that most Pleistocene and Pliocene tephra layers originated from non-alkali volcanism, whereas Miocene tephra layers originated from two different, simultaneous volcanic activities.

Glass shards of the tephra layers from the three sites seem to be hydrated, but visible alteration or hydrated rims of glass shards cannot be detected by optical observation. Electron-microprobe analysis of glass shards shows that most with the chemical composition of rhyolite or basalt are homogeneous from rim to core.

A correlation was established between refractive index and $\mathrm{SiO}_{2}$ content of glass shards. This is summarized as follows: (1) at $\mathrm{SiO}_{2}$ contents of 72 to 73 weight per cent, the refractive index is about 1.5; (2) as the $\mathrm{SiO}_{2}$ content decreases, the refractive index increases proportionately, but the trend deviates slightly from a linear relationship at $\mathrm{SiO}_{2}$ contents between 55 and 65 weight per cent. The correlation between refractive index and total iron oxide is better than that between refractive index and $\mathrm{SiO}_{2}$ content. There is a linear relation between refractive index and total iron oxide.

It is clear that the tephra layers from the central part of the Shikoku Basin have been derived from several different volcanic sources with different rock series. Most of the Pleistocene and Pliocene tephra layers in this region range in composition from rhyolite to dacite (non-alkali). These tephra layers are assumed to be ejec- ta produced by relatively large-scale eruptions in an island arc and transported toward the east.

In contrast, the Miocene tephra layers range in composition from rhyolite to basalt and belong to both the non-alkali and alkali series. In these tephras, the grain size of basaltic glass shards is usually greater than that of rhyolitic shards. This implies that sources of basaltic tephras were closer to the drilling sites than those of rhyolite and andesite tephras. Tephras with large alkali content may be from alkali rocks of the Kinan seamount chain in the central part of the Shikoku Basin. There is also the Izu-Shichito-Iwo Jima volcanic arc east of the drill sites; however, the history of this arc is not well understood. Activity of this arc probably spans the early Miocene to the Holocene; thus, this arc may be one of the sources of the tephra layers.

\section{Clay Mineralogy}

\section{Shikoku Basin}

Except in basalts, rare ash beds, and thin pelagic clays overlying basalts, clay minerals of late-Cenozoic deposits of the Shikoku backarc basin were derived essentially from alteration and erosion of emergent rocks. (See Chamley, this volume). That the clay minerals are mainly terrigenous is supported by geochemical studies (Sugisaki, this volume). The distribution of each mineral at each of the three sites and their main distribution characteristics in continental rocks and recent sediments allow presentation of a scheme for the dominant detrital sources: Japanese Islands and then eastern Asia for chlorite and illite; Asia for vermiculite and attapulgite (palygorskite); volcanic arcs for smectite; southwest Asia through Kuroshio for kaolinite; Japan, Asia, and island arcs for the irregular mixed-layer clays.

The stratigraphic evolution of clay sedimentation in Shikoku Basin since its formation appears to have been under the control of geodynamic factors from the early to late Miocene, and climatic factors from the latest Miocene to the present. This evolution corresponds to a very progressive passage from one influence to the other; gradual diminution of volcanic effects during early basin formation, followed by gradual augmentation of climatic effects in moving toward the Pliocene-Pleistocene cooling. No significant change affects kaolinite abundance, which suggests the establishment of major current systems (Kuroshio) in the north Philippine Sea during the early stages of basin formation.

Detrital clay sedimentation at the three Shikoku Basin sites appears to be a reflection of physiographic changes since the formation of the northern Philippine Sea. The main cause of mineralogical variations recorded in marine sediments is the formation and subsequent subsidence of emergent barriers formed by volcanic ridges, which influence oceanic circulation, local or distant supplies, and resedimentation mechanisms. The most important structures intervening since the middle Miocene are the Iwo Jima-Bonin and the Kyushu-Palau Ridges. The latter apparently was very active until the late Pliocene and subsided in two stages during the Pleistocene. 


\section{Daito Ridge and Basin Region}

The following points are significant in considering the distributions of clay minerals in the Daito Ridgeand-Basin sites.

1. If it can be assumed that the clay fraction in the basalt sills was formed by in situ alteration, then the clay fraction of the interbedded sediments was chiefly derived by detrital supply from volcanic rocks on surrounding island arcs which formed in the early Eocene. This assumes strong volcanic activity and a wide distribution of volcanic rocks in the Daito Ridge area, probably contemporaneous with the development of the Philippine back-arc basin. The warm climate prevailing during the Eocene in numerous areas of the world favored degradation of emergent rocks and formation of smectite, especially in the Daito Ridge area, which had to sub-equatorial conditions (Kinoshita, this volume).

2. During the middle Eocene to middle Oligocene, the Daito Ridge area was still strongly affected by island-arc volcanic activity. Compared to the early Eocene, the consequence was either a slight decrease of volcanic activity, allowing significant erosion of preexisting non-basaltic rocks on the Daito Ridge, or a local uplift of the entire area, leading to sub-aerial erosion of the old ridge substratum. The abundance of middle-Eocene coarse rock fragments in the sequence favors the second hypothesis.

From the late Eocene to middle Oligocene, the reoccurrence of an almost exclusively smectitic clay supply indicates either resurgence of volcanic activity or partial subsidence of Daito Ridge area. The transition from coarse epicontinental sediments (angular lithic fragments, large Nummulites) to finer deposits suggests progressive subsidence of the Daito Ridge, described for many aseismic ridges. Volcanic activity probably was still extensive, as shown by the relative abundance of glass particles and ashy levels in the Cenozoic sediments. (See Site reports, this volume.)

3. During the late Oligocene to Pleistocene, the Daito area received clay minerals from more-distant areas, implying the establishment of large-scale water exchange. This interpretation assumes a general subsidence of the aseismic ridge, probably accompanied by diminution of local volcanic activity. The increased detrital contribution from crystalline and older sedimentary rocks (chlorite, illite, quartz, amphiboles) and from moderately altered continental material (irregular mixed-layer clays, degraded smectite) is a worldwide phenomenon and corresponds to general Cenozoic cooling (Chamley, in press).

\section{Sandstone Diagenesis}

The sandstones in the basal part of the sequence at Site 445 consist of andesitic volcaniclastic fragments and fragments of larger foraminifers. These sandstones were derived from an island arc. Transport of this sediment was by gravity processes, mostly turbidity currents, debris flow and slumping.

Progressive down-hole changes occur in authigenic components. These include initial rim cementation of grains by smectite and mordenite, subsequent pressure welding and pore-space reduction, and later pore filling by sparry-calcite cement. Carbonate materials recrystallize with depth. Carbonate minerals replace plagioclase and volcaniclastic rock fragments at increasing depth. Another replacement, also depth-dependent, is chertification of rock fragments; this replacement increases down-hole.

These vertical changes are clearly a function of depth of burial. The effect of regionally high heat flow could not be evaluated because of lack of temperature data from the drill site.

\section{Sediment-Accumulation Rates}

Age-depth plots for Sites 442, 443, 444, 445, and 446 are shown in the respective site reports (this volume). These plots are uncorrected for compaction or water content.

Sediment-accumulation rates were determined for each lithofacies (Table 14) and by geological age (Table 15). Table 14 shows that sediment-accumulation rates tend to vary with each lithofacies. Thus, high rates of sediment accumulation would be expected in and are characteristic of the resedimented clastic facies of Site 445 and the resedimented mudstone facies at Site 446. Moderate rates of accumulation are characteristic of hemipelagic mudstones. A comparison of sediment-accumulation rates at Site 445 in the resedimented carbonate facies and the pelagic biogenic carbonate facies is instructive: the pelagic facies shows a higher rate of accumulation than the resedimented carbonate facies. Al-

TABLE 14

Sediment-Accumulation Rates at Sites 442, 443, 444, 445 , and 446 by Lithofacies (m/m.y.)

\begin{tabular}{lcccccc}
\hline & \multicolumn{5}{c}{ Sites } \\
\cline { 2 - 6 } \multicolumn{1}{c}{ Major Lithofacies } & 442 & 443 & 444 & 445 & 446 \\
\hline Hemipelagic clay & - & - & - & - & 3.8 \\
Hemipelagic mudstone & 18.2 & - & 16.0 & - & - \\
Resedimented mudstone & - & 28.1 & 11.8 & - & 65.2 \\
Resedimented sandstone & - & - & - & - & - \\
Resedimented conglomerate & - & - & - & - & - \\
Resedimented clastic & - & - & - & 82.5 & - \\
Resedimented carbonate & - & - & - & 11.6 & - \\
Pelagic non-biogenic & 13.0 & - & - & - & - \\
Pelagic calcareous & - & 3.0 & - & 28.2 & - \\
Pelagic siliceous & - & - & - & 20.4 & - \\
Pyroclastic & 11.0 & 33.0 & - & - & - \\
\hline
\end{tabular}

TABLE 15

Sediment-Accumulation Rates at Sites 442, $443,444,445$ and 446 by Age (m/m.y.)

\begin{tabular}{lrrrrr}
\hline & \multicolumn{5}{c}{ Sites } \\
\cline { 2 - 6 } \multicolumn{1}{c}{ Age } & 442 & 443 & 444 & 445 & 446 \\
\hline Pleistocene & 102.5 & 75.0 & 30.0 & 40.9 & 3.1 \\
Pliocene & 7.1 & 7.6 & 8.9 & 29.3 & 1.5 \\
Miocene & 9.2 & 19.6 & 20.9 & 17.3 & 5.0 \\
Oligocene & - & - & - & 17.6 & 1.9 \\
Eocene & - & - & - & 41.0 & 29.5 \\
\hline
\end{tabular}


TABLE 16

Comparison of Sediment-Accumulation Rates by Lithofacies from Sites 285 and $286^{\mathrm{a}}$ and Sites 445 and $446(\mathrm{~m} / \mathrm{m} . \mathrm{y}$.)

\begin{tabular}{|c|c|c|c|c|}
\hline \multirow[b]{2}{*}{ Facies } & \multicolumn{4}{|c|}{ Sites } \\
\hline & 285 & 286 & 445 & 446 \\
\hline Resedimented sandstone and mudstone & 207 & 150 & - & 65 \\
\hline Resedimented conglomerate & - & 200 & - & - \\
\hline Resedimented clastic & - & - & 82.5 & - \\
\hline Pelagic carbonate & 30 & 17 & 28.2 & - \\
\hline Resedimented carbonate & - & - & 11.6 & - \\
\hline Pelagic clay & 5 & $7-13$ & - & 3.8 \\
\hline
\end{tabular}

${ }^{\mathrm{a}}$ Klein, 1975b, table 1.

though 80 per cent of the total carbonate section at Site 445 is resedimented, the accumulation rates are lesser simply because the rate is dependent on the availability of carbonate pelagic materials which are subsequently resedimented. Thus, although resedimentation of carbonate components is a dominant feature of carbonate sedimentation at Site 445 , the rate of sediment accumulation of the resedimented carbonate facies is dependent on availability and original rate of accumulation of pelagic biogenic carbonate sediment. The sediment-accumulation rate of resedimented carbonates may not necessarily be higher than that for associated pelagic carbonate sediments. Caution must be exercised in using sediment-accumulation rates as a criterion of resedimentation of pelagic biogenic carbonate sediments.

Within individual lithofacies (Table 14), variability in sediment-accumulation rates appears to be a function of distance from probable sediment sources. Thus, the difference in sediment-accumulation rates for the resedimented mudstone facies at Sites $443(28.1 \mathrm{~m} / \mathrm{m} . \mathrm{y}$.) and $444(11.8 \mathrm{~m} / \mathrm{m} . \mathrm{y}$.) clearly represents a difference between deposition on the medial portion of a clastic wedge and a distal portion of a clastic wedge, respectively. The difference in rates in the pyroclastic facies at Site $442(11.0 \mathrm{~m} / \mathrm{m} . y$.$) and 443(33.0 \mathrm{~m} / \mathrm{m} . \mathrm{y}$.$) , is con-$ trolled by the proximity of the Kinan Seamounts near Site 443.

Table 15 shows that at all sites the Pleistocene is characterized by relatively high rates of sediment accumulation compared to those of the Pliocene or Miocene. The Miocene is characterized by higher rates of accumulation than the Pliocene, and (at Site 446) the Oligocene and the Eocene are characterized by high rates of sediment accumulation. The Eocene rates are high at Sites 445 and 446 only because they represent the resedimented clastic lithofacies and its subfacies. This facies, consisting of interbedded debris flow conglomerates and turbidite sandstones and mudstones, also extends into the Oligocene at Site 445, accounting for a higher Oligocene accumulation rate there. The Miocene rates embrace a variety of sediment facies and appear more to be related to increased volcanism, known both in the western Pacific (Donnelly, 1975; Kennett et al., 1977) and the circum-Pacific (Kennett et al., 1977). The ash beds in the Miocene supports this interpretation. Another factor contributing to slightly higher rates of accumu- lation during the Miocene is the increased influx of continental-derived clays in the Shikoku Basin, a trend which apparently persisted through the late Cenozoic into the Quaternary. The known Pliocene decrease in volcanism in the western Pacific (Donnelly, 1975) may well account for lower rates of accumulation during that time.

The high sediment-accumulation rates observed for Pleistocene sediments at all sites can be related to two factors. The first is an increase in regional volcanism common to much of the circum-Pacific during Pleistocene time (Kennett et al., 1977); the recovery of volcanic ash in Pleistocene sediments at several of the sites (443, $444,445)$ supports this interpretation. A second factor is the effect of lower stands of sea level during periods of Pleistocene glacial advance, and it clearly accounts for the higher content of terrigenous hemipelagic clays in Pleistocene sediments from the Shikoku Basin. Such lower stands of sea level would expose shelf areas and areas marginal to coastlines of land sources such as the Asian mainland and the Japanese Islands; they also would entrench river systems to a lower base level. These rivers would be extended across former shelf and coastal regions and increase sediment supply to the back-arc basins of the northwest Pacific. The increased volume of terrigenous sediment and rate of sediment accumulation for the Quaternary of Leg 58 cores clearly result from this increased sediment yield.

In summary, analysis of the sediment-accumulation rates for Leg 58 sites has demonstrated that (1) within individual lithofacies, variations in rates of sediment accumulation are a function of distance from both continental and volcanic sources; (2) rates of accumulation of resedimented biogenic pelagic carbonates are dependent on the original volume and rate of sediment accumulation of pelagic biogenic carbonate deposition, and not the resedimentation process per se; (3) the increased rates of sediment accumulation observed for the Eocene at two sites is a function of the dominance of gravity sedimentation; (4) the increased rates of accumulation during the Miocene were dependent on increased regional volcanism, and (5) the increased rates of sediment accumulation during the Pleistocene were a function of both increased regional volcanism and increased sediment yield from land during lower stands of sea level.

\section{Comparison of Shikoku Basin and Daito Ridge and Basin Sedimentation to that in Other Back-Arc Basins in the Western Pacific}

The sedimentary facies successions in the Shikoku Basin and the Daito Ridge and Basin province show both differences and similarities with the sedimentary facies encountered in other back-arc basins of the western Pacific. Drilling during DSDP Legs 6, 20, 21, 29, 30 , and 31 disclosed a variety of sedimentation styles in each of the back-arc basins in the western Pacific. Most of these basins are characterized by wedges of volcaniclastic turbidites (Fischer, Heezen, et al., 1971; Burns, Andrews, et al., 1973; Karig, Ingle, et al., 1975; Andrews, Packham, et al., 1975; Klein, 1975a,b, 1977; Karig and Moore, 1975) which intertongue with and are 
overlain by pelagic sediments. The pelagic sediments are either biogenic calcareous or siliceous oozes, or clays.

Pelagic sedimentation occurred simultaneously with deposition of volcaniclastic wedges, but such pelagic sediments were subordinate in volume to the volcaniclastic material accumulated by subaqueous gravity flows. Pelagic processes appear to become dominant only when supply of volcaniclastic sediments ceased. In some basins, facies are asymmetrically distributed across the basin, as in the west Philippine Basin (Karig and Moore, 1975), whereas in other basins, such as the Sea of Japan (Schlanger and Combs, 1975) and the South Fiji and Hebrides Basins (Klein, 1975a,b, 1977), clastic wedges are disposed symmetrically with respect to the mid-basin spreading center.

The Shikoku Basin sediment succession reveals a history much different from that of any of the other basins. Seismic study of the Shikoku Basin showed that it is floored by a rough acoustic-basement topography (Karig, Ingle, et al., 1975; Marauchi and Asanuma, $1974,1977)$ and that during earliest sedimentation the topographic lows were filled as sediment ponds, followed by regional deposition. Seismic profiles obtained by Marauchi and Asanuma $(1974,1977)$, during DSDP Leg 31 (Karig, Ingle, et al., 1975) and during Leg 58 (this volume) also demonstrated that the sediment cover over the basin consists of a series of coalescing clastic wedges. To date, three clastic wedges have been recognized from seismic study and contouring of the sediment cover overlying acoustic basement (Figure 20).

These clastic wedges include one on the north side of the basin penetrated at DSDP Site 297; one on the west side of the basin, penetrated at Site 442; and one on the east side of the basin, penetrated at Sites 443 and 444 . Site 297 was drilled in the medial part of the northern clastic wedge, whereas Sites 442,443 , and 444 are on distal toes of both the western and eastern wedges (Figure 20).

These clastic wedges apparently were derived from sources in the direction of thickening of these wedges. Thus, the northern wedge was probably derived from the Japanese Islands (Karig, Ingle, et al., 1975), whereas the western and eastern wedges were derived from the remnant arc of the Kyushu-Palau Ridge, and from the Iwo Jima Ridge (an active arc), respectively. Supply of sediment from the remnant arc of the Kyushu-Palau Ridge appears to have been continuous, but the supply of sediment to the northern clastic wedge was presumably reduced or eliminated with the Pliocene development of the Nankai Trough, into which most of the northerly derived sediment accumulated since that time (Karig, Ingle, et al., 1975).

Evidence for the relative proximity of Site 297 in the northern clastic wedge consists in turbidites with welldeveloped Bouma sequences and the overall thickness of the early Pliocene. Proof of the distal location of the hemipelagic sediments at Sites 442,443 , and 444 consists in dominantly hemipelagic clay and, at Site 444 , biogenic pelagic sediments interbedded with hemipelagic mud. Sediments at Site 444 were deposited in a moredistal part of the eastern clastic wedge than at Site 443,
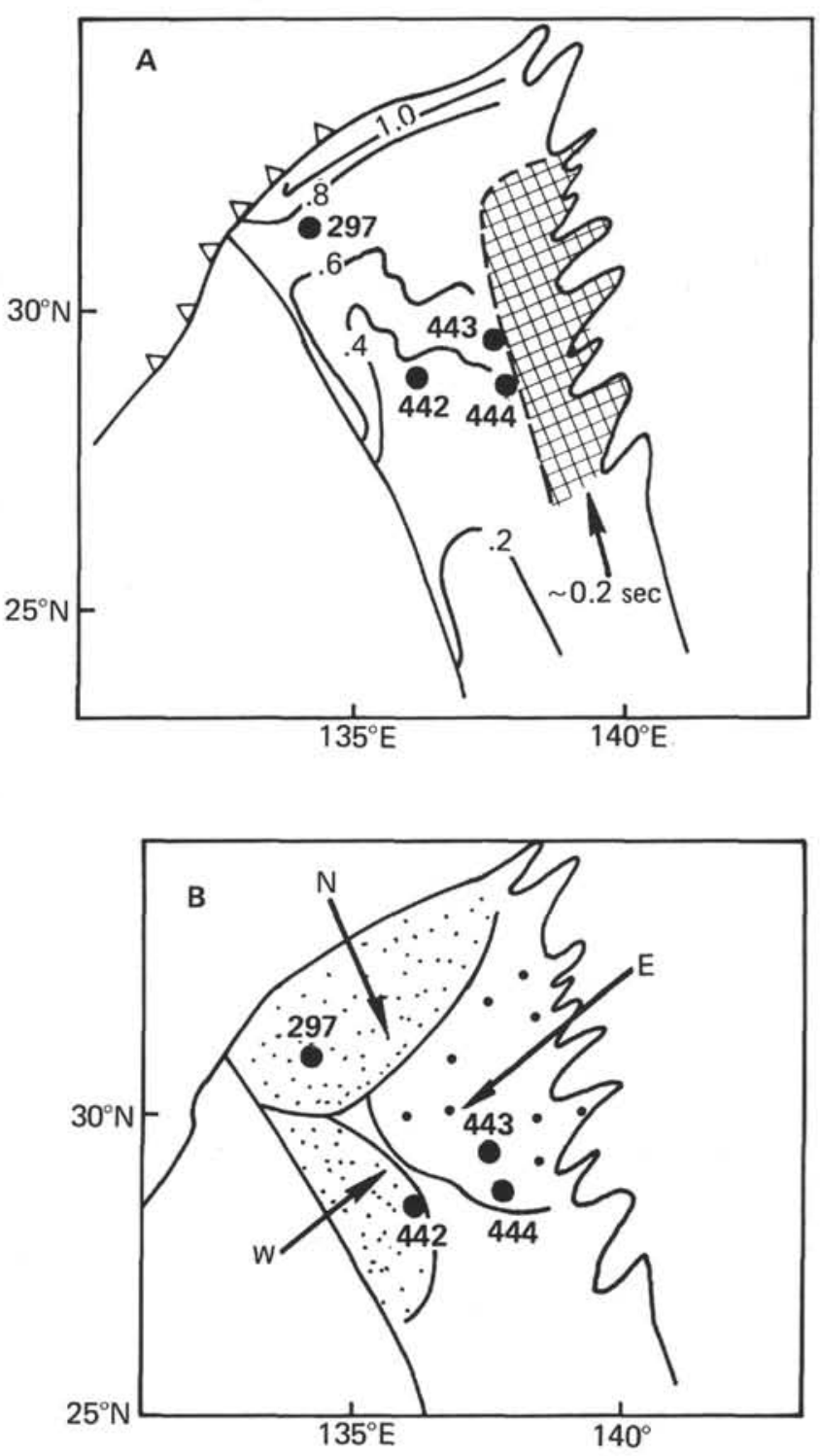

Figure 20. A. Isopach map of sediment thickness in the Shikoku basin (in seconds), above acoustic basement (from Karig, 1975, fig. 3, p. 862). B. Location of clastic wedges, general sediment-dispersal trends (arrows), and direction of clastic-wedge derivation over the past 15 m.y. in the Shikoku Basin.

as inferred from the lower volume and lesser thickness of hemipelagic clays and the lower rates of sedimentation. A few layers of well-developed interbedded nannofossil and radiolarian oozes indicate periods of slight increases in biogenic pelagic sedimentation. These interbeds are rare at Site 443 and absent at Site 442 .

Figure 21 summarizes the stratigraphy of Sites 297, 442,443 , and 444 . The thick Pliocene sequence at Site 297 clearly reflects deposition in the medial to distal part of the northern clastic wedge (Karig, Ingle, et al., 1975), whereas the relatively thin Pliocene sections at Sites 442, 443 , and 444 reflect distal deposition. The Quaternary sections at Sites 442 and 443 , however, are relatively thick for a distal position, whereas the Quaternary sec- 


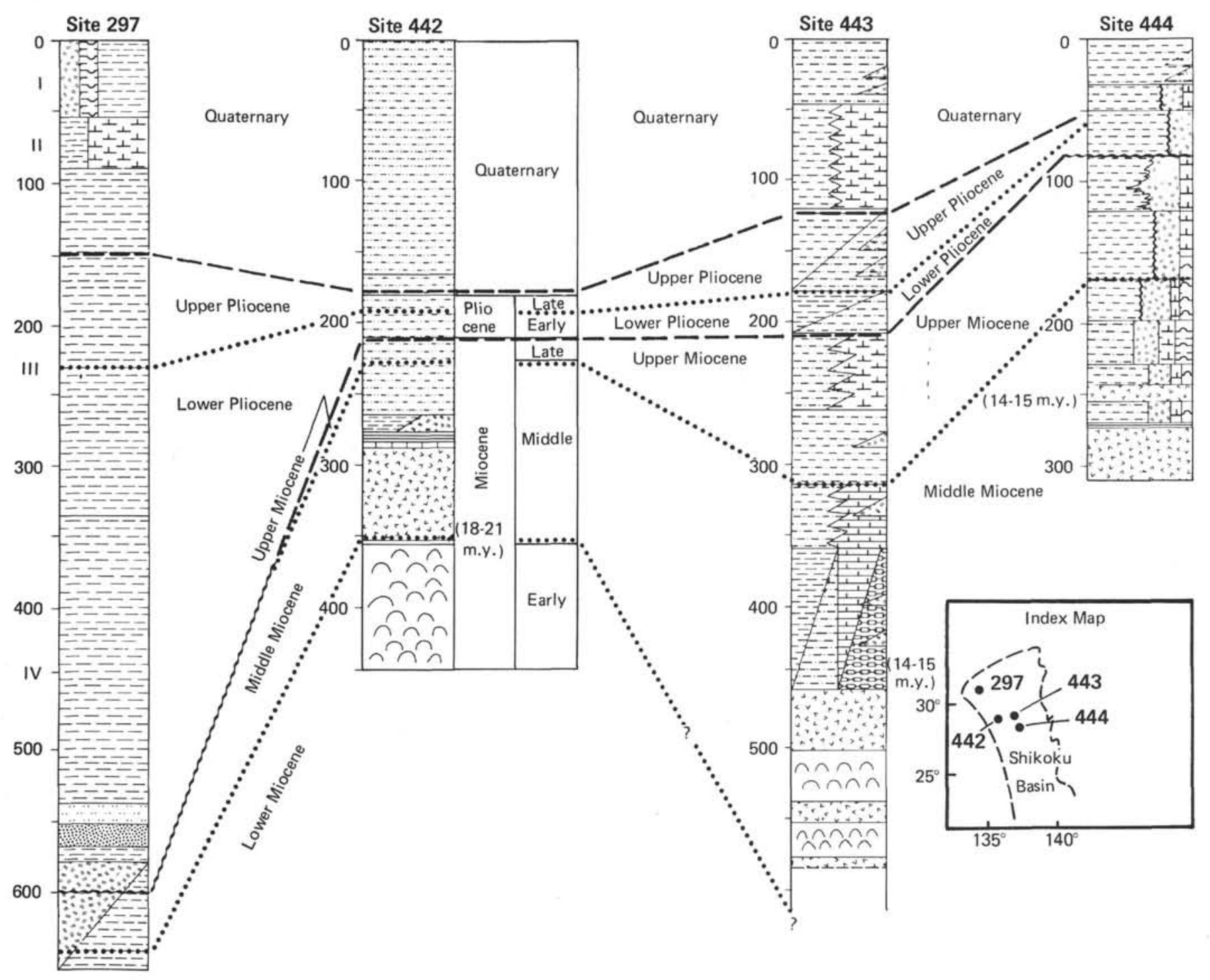

Figure 21. Time-stratigraphic correlation of sediments of Sites 297, 442, 443, and 444.

tion at Site 444 is consistent with distal clastic-wedge deposition. Thicker Quaternary deposits at Sites 297, 442 , and 443 are consistent with known greater rates of sediment accumulation at those sites. The greater rates resulted from active Quaternary circum-Pacific volcanism (Donnelly, 1975; Kennett et al., 1977) and from fluctuations in sea level. During low stands, the effluent of high-yield streams would enter the ocean closer to the basin center than during higher stands of sea level. In a typical distal location, such as Site 444 , the influence of such lowering of sea level would be lesser.

The centripetal pattern of sedimentation from at least three sources into the Shikoku Basin is one of its unique features in comparison with the other back-arc basins of the western Pacific. The clastic wedges and associated dispersal patterns in the other back-arc basins of the western Pacific are highly variable. Karig and Moore (1975) showed that in the Parece Vela Basin and the southern half of the Philippine Sea clastic wedges are asymmetrical with respect to a single, linear island-arc source, from which they thin towards the basin center.
Klein $(1975 \mathrm{a}, \mathrm{b})$ suggested a symmetrical disposition of such clastic wedges from island-arc sources in the South Fiji and New Hebrides Basin, and later (Klein, 1977) suggested that this disposition was a function of the radius of curvature of the island-arc sources. The Philippine Sea and Parece Vela Basin are filled with an asymmetrical clastic wedge, because the island-arc source is nearly linear, whereas in the South Fiji Basin the radius of curvature of the bounding island arc is small, giving rise to a symmetrical disposition of clastic wedges. The Sea of Japan differs from the South Fiji Basin because there symmetrically disposed clastic wedges are both terrigenous (Asian mainland) and from an island-arc source (Japanese Islands) (Schlanger and Combs, 1975). The Shikoku Basin is unique among Pacific Ocean backarc basins, having clastic wedges derived from two active island arcs oriented normal to each other (Japanese Islands, Iwo Jima Ridge), and from a remnant arc (Kyushu-Palau Ridge).

The dominance of hemipelagic sediment is a second major difference between the Shikoku Basin sediments 
and other Pacific Ocean back-arc basins. The hemipelagic sediments were derived from several sources and appear to show a systematic change in clay mineralogy through time. These mineral changes reflect increasing supply from the Chinese mainland and global cooling since the Miocene. No such systematic changes in clay mineralogy have been reported from other back-arc basins.

The depth of deposition of all the Shikoku Basin sites is near the CCD. At Sites 297, 442, 443, and 444, a few horizons barren of fossils were documented, indicating deposition below the CCD. The poorly preserved nannoplankton and lack of foraminifers suggest deposition above the $\mathrm{CCD}$, but below the lysocline. Short periods of known deposition below the CCD in the Shikoku Basin include parts of the Pleistocene, the early Pliocene, and the late Miocene. The alternation of calcareous and sometimes siliceous fossil deposits and inorganic terrigenous deposits at Site 443 indicates some changes in the $\mathrm{CCD}$, perhaps related to the general current system and sea-level variations during the late Cenozoic.

The Daito Ridge and Basin province is a complex terrain subdivided into deeper-water basins and relative shallower ridges which are remnant arcs (Mizuno et al., 1975; Karig, 1975; Shiki et al., 1974). Site 445 is in a small basin in the Daito Ridge, whereas Site 446 is in the Daito Basin.

The succession of sedimentary facies in the Daito Ridge and Basin province shows similarity to the facies succession at Site 285 (South Fiji Basin) and Site 286 (Hebrides Basin), drilled during DSDP Leg 30 (Andrews, Packham, et al., 1975) (Figure 22).

The stratigraphic and sedimentological framework of deposition of the two sites is very different, but despite these differences, the two sites show much similarity. The younger part of the section (post-Eocene) at both sites consists of pelagic sediments, whereas the Eocene at both sites consists of well-developed terrigenous mudstones, siltstones, sandstones, and (at Site 445) conglomerates. These Eocene sediments were deposited by the complete range of subaqueous gravity processes, including slumping, debris flows, fluidized-sediment flows, and turbidity currents. The rates of sediment accumulation at both sites show a nearly identical pattern, low to moderate for the post-Eocene pelagic section, and moderate to high for the Eocene terrigenous sediments. This pattern of sediment-accumulation rates is identical to that reported from Site 285 in the South Fiji Basin and Site 286 in the New Hebrides Basin by Andrews, Packham et al. (1975) and Klein (1975a,b).

\section{ACKNOWLEDGMENTS}

The authors, first of all, thank their shipboard and shorebased colleagues who contributed time, efforts, and data contributing to this paper. Dr. Peter Borella of Riverside City College and C. John Mann of the University of Illinois, Urbana, reviewed the manuscript and made helpful criticisms, comments, and suggestions. Mrs. Lola Boyce of DSDP went above and beyond the call of duty to type, retype, and proofread the many drafts.

\section{REFERENCES}

Andrews, J. E., Packham, G. H., et al., 1975. Init. Repts., $D S D P, 30$ : Washington (U. S. Govt. Printing Office).

Berger, W. H., 1973. Cenozoic sedimentation in the eastern tropical Pacific. Geol. Soc. Am. Bull., 84, 1941-1951.

Berger, W. H., and von Rad, U., 1972. Cretaceous and Cenozoic sediments from the Atlantic Ocean. In Hays, D. E., Pimm, A. C., et al., Init. Repts. DSDP, 14: Washington (U. S. Govt. Printing Office), pp. 787-954.

Berggren, W. A., 1972. A Cenozoic time-scale-some implications for regional geology and paleogeography. Lethaia, 5, 195-215.

Berggren, W. A., and Van Couvering, J. A., 1974. The late Neogene biostratigraphy, geochronology and paleoclimatology of the last 15 million years in marine and continental sequences. Palaeogeography, Palaeoclimatology, Palaeoecology, 16, 1-216.

Bouma, A. H., 1962. Sedimentology of Some Flysch Deposits: Amsterdam (Elsevier).

Boyce, R. E., 1976a. Definitions and laboratory techniques of compressional sound velocity parameters and wet-water content, wet-bulk density, and porosity parameters by gravimetric and gamma ray attenuation techniques. In Schlanger, S. O., Jackson, E. D., et al., Init. Repts. DSDP, 33: Washington (U. S. Govt. Printing Office), pp. 931-951. $1976 \mathrm{~b}$. Sound velocity-density parameters of sediment and rock from DSDP drill Sites 315-318 on the Line Islands Chain, Manihiki Plateau, and Tuamotu Ridge in the Pacific Ocean. In Schlanger, S. O., Jackson, E. D., et al., Init. Repts. DSDP, 33: Washington (U. S. Govt. Printing Office), pp. 695-728.

Bukry, D., 1975. Coccolith and silicoflagellate stratigraphy, northwestern Pacific Ocean, Deep Sea Drilling Project, Leg 32. In Larson, R. A., Moberly, R. M., Jr. et al., Init. Repts. DSDP, 32: Washington (U. S. Govt. Printing Office), pp. 677-718.

Burns, R. E., Andrews, J. E., et al., 1973. Init. Repts. DSDP, 21: Washington (U. S. Govt. Printing Office).

Busch, W. H., 1976a. A model of the origin of dish structures in some ancient subaqueous sandy debris flow deposits. Geol. Soc. Am. Abs. with Programs, 8, 799.

1976b. Dish structures in some ancient subaqueous sandy debris flow deposits, M. S. thesis, University of Illinois, Urbana.

Chamley, H., in press. North Atlantic clay sedimentation and paleoenvironment since the late Jurassic: Second Ewing Symposium, New York.

Clark, S. P., Jr., 1966. Thermal conductivity. In Clark, S. P., Jr., (Ed.), Handbook of Physical Constants: Geol. Soc. Am. Mem., 97, 459-482.

Cook, H. E., Jenkyns, H. C. and, Kelts, K. R., 1976. Redeposited sediments along the Line Islands, Equatorial Pacific. Schlanger, S. O., Jackson, E. D., et al., Init. Repts. DSDP, 33: Washington (U. S. Govt. Printing Office), pp. 837-847.

Dagley, P., and Lawley, E., 1974. Paleomagnetic evidence for the transitional behavior of the geomagnetic field. Geophys. J. Royal Astron. Soc., 36, 577-598.

Davies, T. A., Luyendyk, B. P., et al., 1975. Init. Repts. $D S D P$, 26: Washington (U. S. Govt. Printing Office).

DeRaaf, J. F. M., Reading, H. G., and Walker, R. G., 1965. Cyclic sedimentation in the Lower Westphalian of North Devon, England. Sedimentology, 4, 1-52.

Donnelly, T. W., 1975. Neogene explosive volcanic activity of the western Pacific, Sites 292 and 296. In Karig, E. D., 

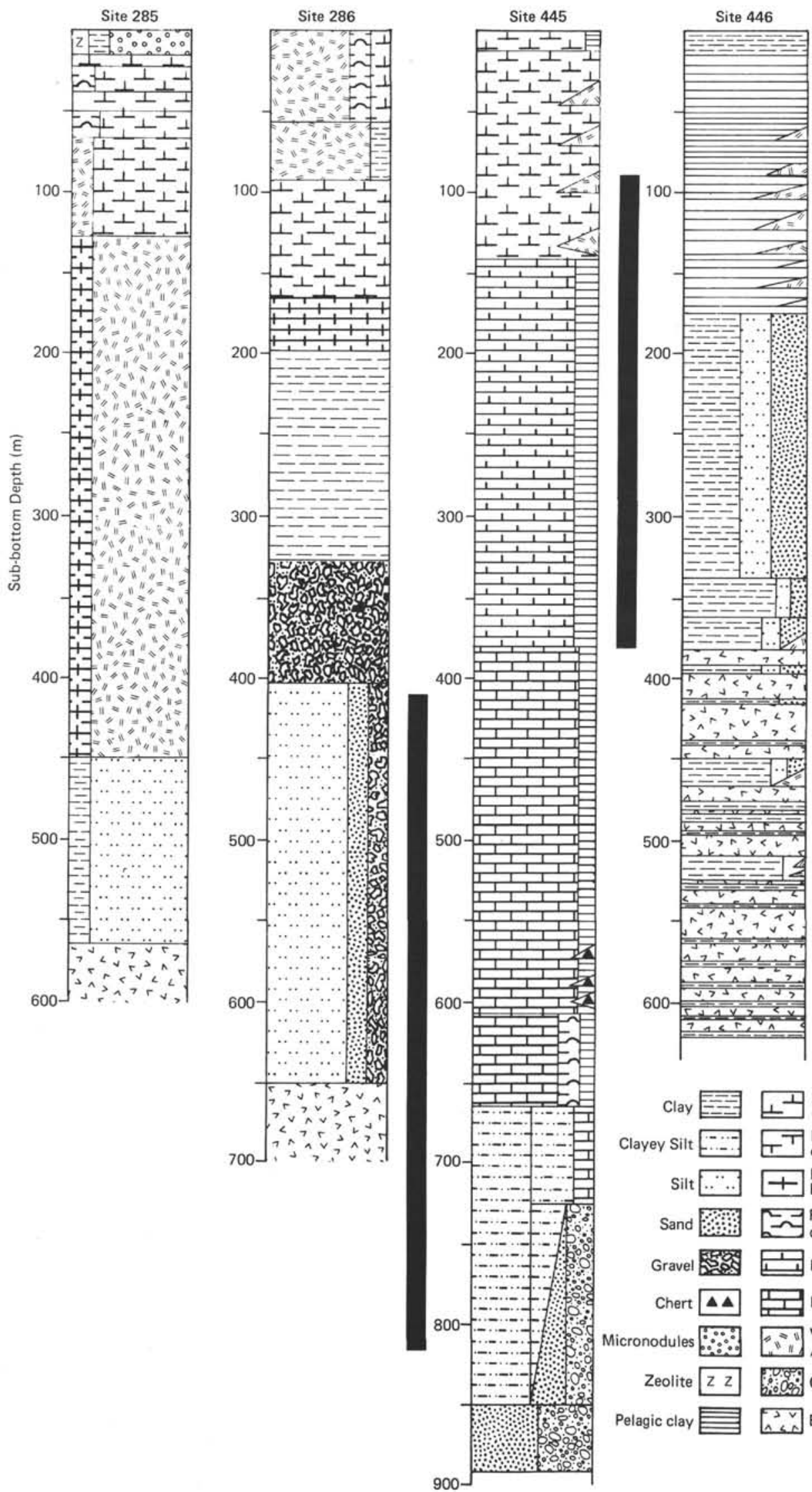
Clay E्: 널 Clayey Silt $\cdots, T$ Foraminifer Silt $\ldots . . .+\square \quad \begin{aligned} & \text { Nannofossil } \\ & \text { Foraminifer ooze }\end{aligned}$ Sand 2 Radiolarian

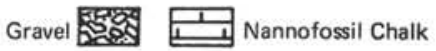 Chert $\Delta \mathbf{\Delta}$ Limestone Micronodules $\because \because 8$ Volcanic Zeolite Z z Conglomerate Pelagic clay 层

Figure 22. Comparison of sedimentary facies and stratigraphy between Sites 285 and 286 (from Andrews, Packham, et al., 1975; Klein, 1975b) and Sites 445 and 446. 
Ingle, J. C., et al., Init. Repts. DSDP, 31: Washington (U. S. Govt. Printing Office), pp. 577-598.

Fischer, A. G., Heezen, B. C., et al., 1971. Init. Repts. DSDP, 6: Washington (U. S. Govt. Printing Office).

Hamilton, E. L., 1974. Prediction of deep-sea sediment properties: state of the art. In Inderbitzen, A. L. (Ed.), Deep Sea Sediments, Physical and Mechanical Properties: New York (Plenum Press), pp. 1-43. 1976. Variations of density and porosity with depth in deep-sea sediments. J. Sediment. Petrol., 46, 280-300. 1978. Sound velocity-density relations in sea-floor sediments and rocks. J. Acoust. Soc. Am., 63, 366-377.

Hampton, M. A., 1972. The role of subaqueous debris flow in generating turbidity currents. J. Sediment. Petrol., 42, 775-793.

Hilde, T. W. C., Uyeda, S., and Kroenke, L., 1977. Evolution of the western Pacific and its margin. Tectonophysics, 38, 145-165.

Hyndman, R. D., Erickson, A. J., and von Herzen, R. P., 1974. Geothermal measurements on DSDP Leg 26. In Davies, T. A., Luyendyk, B. P., et al., Init. Repts. DSDP, 26: Washington (U. S. Govt. Printing Office), pp. 451-464.

Ingle, J. C., Jr., 1975. Summary of late Paleogene-Neogene insular stratigraphy, paleobathymetry, and correlations, Philippine Sea and Sea of Japan region. In Karig, D. E., Ingle, J. C., Jr., et al., Init. Repts. DSDP, 31: Washington (U. S. Govt. Printing Office), pp. 837-855.

Karig, D. E., 1970. Ridges and basins of the Tonga-Kermadec Island arc system. J. Geophys. Res., 75, 239-255. 1971. Origin and development of marginal basins in the western Pacific. J. Geophys. Res., 76, 2542-2561. 1975. Basin genesis in the Philippine Sea. In Karig, D. E., Ingle, J. C., et al., Init. Repts. DSDP, 31: Washington (U. S. Govt. Printing Office), pp. 857-879.

Karig, D. E., Ingle, J. C., et al., 1975. Init. Repts. DSDP, 31: Washington (U. S. Govt. Printing Office).

Karig, D. E., and Moore, G. F., 1975. Tectonically controlled sedimentation in marginal basins. Earth Planet. Sci. Lett., 26, 233-238.

Kennett, J., Houtz, R., et al., 1975. Init. Repts. DSDP, 29: Washington (U. S. Govt. Printing Office).

Kennett, J. P., McBirney, A. R., and Thunell, R. C., 1977. Episodes of Cenozoic volcanism in the circum-Pacific region. J. Volcanol. Geochem. Res., 2, 145-163.

Kennett J. P., and Thunell, R. C., 1977. Comments on Cenozoic explosive volcanism related to east and southeast Asian arcs. In Talwani, M., and Pitman W. C. (Eds.), Island Arcs, Deep Sea Trenches and Back Arc Basins, (Maurice Ewing Series 1): Washington (Am. Geophys. Union), pp. 348-352.

Klein, G. deV., 1975a. Depositional facies in Leg 30 Deep Sea Drilling Project cores. In Andrews, J. E., Packham, G. H., et al., Init. Repts. DSDP, 30: Washington (U. S. Govt. Printing Office), pp. 423-442.

1975b. Sedimentary tectonics in southwest Pacific marginal basins based on Leg 30 Deep Sea Drilling Project Cores from the South Fiji, Hebrides and Coral Sea Basins. Geol. Soc. Am. Bull., 86, 1012-1018.

1977. Subaqueous gravity flow sedimentation in the marginal basins of the western Pacific Ocean. Geol. Soc. Am. Abs. Programs, 9, 1052.

Kobayashi, K., and Isezaki, N., 1976. Magnetic anomalies in the Sea of Japan and the Shikoku Basin: possible tectonic implications. In The Geophysics of the Pacific Ocean Basin and its Margin: Am. Geophys. Union Mon., 19, pp. 235251.
Kobayashi, K., and Nakada, M., 1977. Local magnetic anomaly profiles, Shikoku Basin, northwestern Pacific Ocean. Contr. Geodynamics Project Japan, 77-2. [map]

Konda, I., Harada, K., Kitazato, H., Matsuoka, K., Nishida, S., Nishimura, A., Ohno, T., and Taka-ama, T., 1975. Some paleontological results of the GDP-1, $-8,-11$ cruises. In Geological Processes of the Philippine Sea: Tokyo (Geol. Soc. Japan), pp. 185-196.

Louden, K. E., 1976. Magnetic anomalies in the West Philippine Basin. In Sutton, G. H., Manghnani, M. H., and Moberly, R. (Eds.), The Geophysics of the Pacific Ocean Basin and its Margin: Am. Geophys. Union Geophys. Mon., 19 , pp. $200-232$.

1977. Paleomagnetism of DSDP sediments, phase shifting of magnetic anomalies and rotation of the West Philippine Basin. J. Geophys. Res., 82, 2989-3002.

Lowe, D. R., 1976. Subaqueous liquified and fluidized sediment flows and their deposits. Sedimentology, 23, 285-308.

Lowe, D. R., and LoPiccolo, R. D., 1974. The characteristics and origins of dish and pillar structures. J. Sediment. Petrol., 44, 484-501.

Matsuda, J., Saito, K., and Zashu, S., 1975. K-Ar age and SR isotope of rocks of manganese nodule nuclei from Amami Plateau, West Philippine Sea. In Nakazawa, K., et al. (Eds.), Geological Problems of the Philippine Sea, pp. 99-101.

Mizuno, A., Okuda, Y., Tamaki, K., Kinoshita, Y., Nohara, M., Yuasa, M., Nakajima, M., Murakami, F., Terashima, S., and Ishibashi, K., 1975. Marine geology and geological history of the Daito Ridge area, northwestern Philippine Sea. Mar. Sci., 7, 484-491, 543-548.

Mizuno, A., Shiki, T., and Aoki, H., 1977. Dredged rock and piston and gravity core data from the Daito Ridges and Kyushu-Palau Ridge in the North Philippine Sea. In Geological Studies of the Ryuku Islands (Vol. 2), pp. 107-119.

Mizuno, A., Okuda, Y., Nagumo, S., Kagami, H. and Nasu, N., 1979. Subsidence of the Daito Ridge and associated basins, North Philippine Sea. In Watkins, J. S., Montadert, L., and Dickerson, P. (Eds.), Geological and Geophysical Investigations of Continental Margins: Am. Assoc. Petrol. Geol. Mem., 29, pp. 100-116.

Moore, C., 1974. Turbidites and terrigenous muds, DSDP Leg 25. In Simpson, E. S. W., Schlich, R., et al., Init. Repts. DSDP, 25: Washington (U. S. Govt. Printing Office), pp. 441-480.

Murauchi, S., and Asanuma, T., 1974. Seismic reflection profiles and sonobuoy refraction measurements during GDP-6 to -8 voyages. Mar. Sci., 6, 23-27. [in Japanese with English abstract] 1977. Seismic Reflection Profiles in the Western Pacific, 1965-1974: Tokyo (Univ. Tokyo Press).

Nelson, C. H., and Kulm, L. V. 1973. Submarine fans and channels. In Middleton, G. V., and Bouma, A. H. (Eds.), Turbidites and Deep-Water Sedimentation: Tulsa (Soc. Econ. Paleontol. Mineral.), pp. 97-109.

Ninkovich, D., and Donn, W. L., 1977. Cenozoic explosive volcanism related to east and southeast Asian arcs. In Middleton, G. V., and Bouma, A. H. (Eds.), Turbidites and Deep-Water Sedimentation: Tulsa (Soc. Econ. Paleontol. Mineral.), pp. 337-347, 353-354.

Nilsen, T. H., and Kerr, D. R., 1978. Turbidites, redbeds, sedimentary structures and trace fossils observed in DSDP Leg 38 cores and the sedimentary history of the NorwegianGreenland Sea. In Talwani, M., Udintsev, G., et al., Init. 
Repts. DSDP, Suppl. to Vols. 38, 39, 40, and 41: Washington (U. S. Govt. Printing Office), pp. 259-288.

Nishida, S., Konda, I., Sudo, T., and Sugano, K., 1978. The Miocene and Oligocene deposits on the Daito Ridges area. Geol. Soc. Japan, Abs. 85th Ann. Mtg., 187. [in Japanese)

Ratcliffe, E. H., 1960. The thermal conductivities of ocean sediments. J. Geophys. Res., 65, 1535-1541.

Saito, T., 1977. Late Cenozoic planktonic foraminifera datum levels: the present state of knowledge towards accomplishing Pan-Pacific stratigraphic correlation. Proc. First Internat. Congr. Pacific Neogene Stratigraphy, 61-80.

Schlanger, S. O., and Combs, J., 1975. Hydrocarbon potential of marginal basins bounded by an island arc. Geology, 3, 397-400.

Scholle, P., 1977. Chalk diagenesis and its relation to petroleum exploration: oil from chalks, a modern miracle? $\mathrm{Am}$. Assoc. Petrol. Geol. Bull., 61, 982-1009.

Shiki, T., Konda, I., Misawa, Y., and Nishimura, A., 1977. Geology and geohistory of the northwestern Philippine Sea, with special reference to the results of the recent Japanese research cruises. Mem. Fac. Sci. Kyoto Univ. Ser. Geol. Mineral., 44, 67-78.

Stauffer, P. H., 1967. Grain-flow deposits and their implications, Santa Ynez Mountains, California. J. Sediment. Petrol., 37, 487-508.

Thiede, J., Perch-Nielsen, K., Supko, P. R., and Boersma, A., 1975. Sediments on Rio Grande Rise (SW Atlantic Ocean): subsidence of an aseismic ridge. Ninth Internat. Congr. Sedimentol., 8, 5-9.

Tomoda, Y., Kobayashi, K., Segawa, J., Nomura, M., Kimura, K., and Saki, T., 1975. Linear magnetic anomalies in the Shikoku Basin, northeastern Philippine Sea. J. Geomagnet. Geoelec., 28, 47-56.

Ujiie, H., 1976: Late Cenozoic planktonic foraminiferal biostratigraphy in the subtropical region of the western North
Pacific. Proc. First Internat. Congr. Pacific Neogene Stratigraphy, pp. 183-204.

van Andel, Tj. H., Heath, G. R., and Moore, T. C., Jr., 1975. Cenozoic history and paleoceanography of the Central Equatorial Pacific Ocean. Geol. Soc. Am. Mem., 143.

van der Lingen, G. J., and Packham, G. H., 1975. Relationships between diagenesis and physical properties of biogenic sediments of the Ontong-Java Plateau (Sites 288 and 289, Deep Sea Drilling Project). In Andrews, J. E., Packham, G., et al., Init. Repts. DSDP, 30: Washington (U. S. Govt. Printing Office), pp. 443-481.

Walker, R. G., 1965. The origin and significance of the primary sedimentary structures of turbidites. Yorkshire Geol. Soc. Proc., 35, 1-32.

, 1975. Generalized facies models for resedimented conglomerates of turbidite association. Geol. Soc. Am. Bull., 86, 737-748.

1978. Deep-water sandstone facies and ancient submarine fans: models for exploration for stratigraphic traps. Am. Assoc. Petrol. Geol. Bull., 62, 932-967.

Walker, R. G., and Mutti, E., 1973. Turbidite facies and facies associations. In Middleton, G. V., and Bouma, A. H. (Eds.), Turbidites and Deep Water Sedimentation: Tulsa (Soc. Econ. Paleontol. Mineral.), pp. 119-158.

Watts, A. N., and Weissel, J. K., 1975. Tectonic history of the Shikoku marginal basin. Earth Planet. Sci. Lett., 25, 239-250.

Wilson, R. L., Dagley, P., and McCormack, A. G., 1972. Paleomagnetic evidence about the source of the geomagnetic field. Geophys. J. Royal Astron. Soc., 28, 213-224.

Yuasa, M., and Watanabe, T., 1977. Pre-Cenozoic metamorphic rocks from the Daito Ridge in the northern Philippine Sea. J. Japan Assoc. Mineral. Petrol. Econ. Geol., 72, 241-251. 



\section{PLATE 1}

Figure $1 \quad$ Resedimented mudstone facies showing parallel laminae. 445-74-5, 10-65 cm.

Figure 2 Resedimented sandstone facies showing dish structures in volcaniclastic, carbonate sandstone. 445$57-7,22-40 \mathrm{~cm}$.

Figure 3 Resedimented sandstone facies showing microfaults. $445-71-1,14-25 \mathrm{~cm}$.

Figure 4 Resedimented sandstone facies showing coarsetail graded bedding. 445-73-2, 98-127 cm. 
PLATE 1
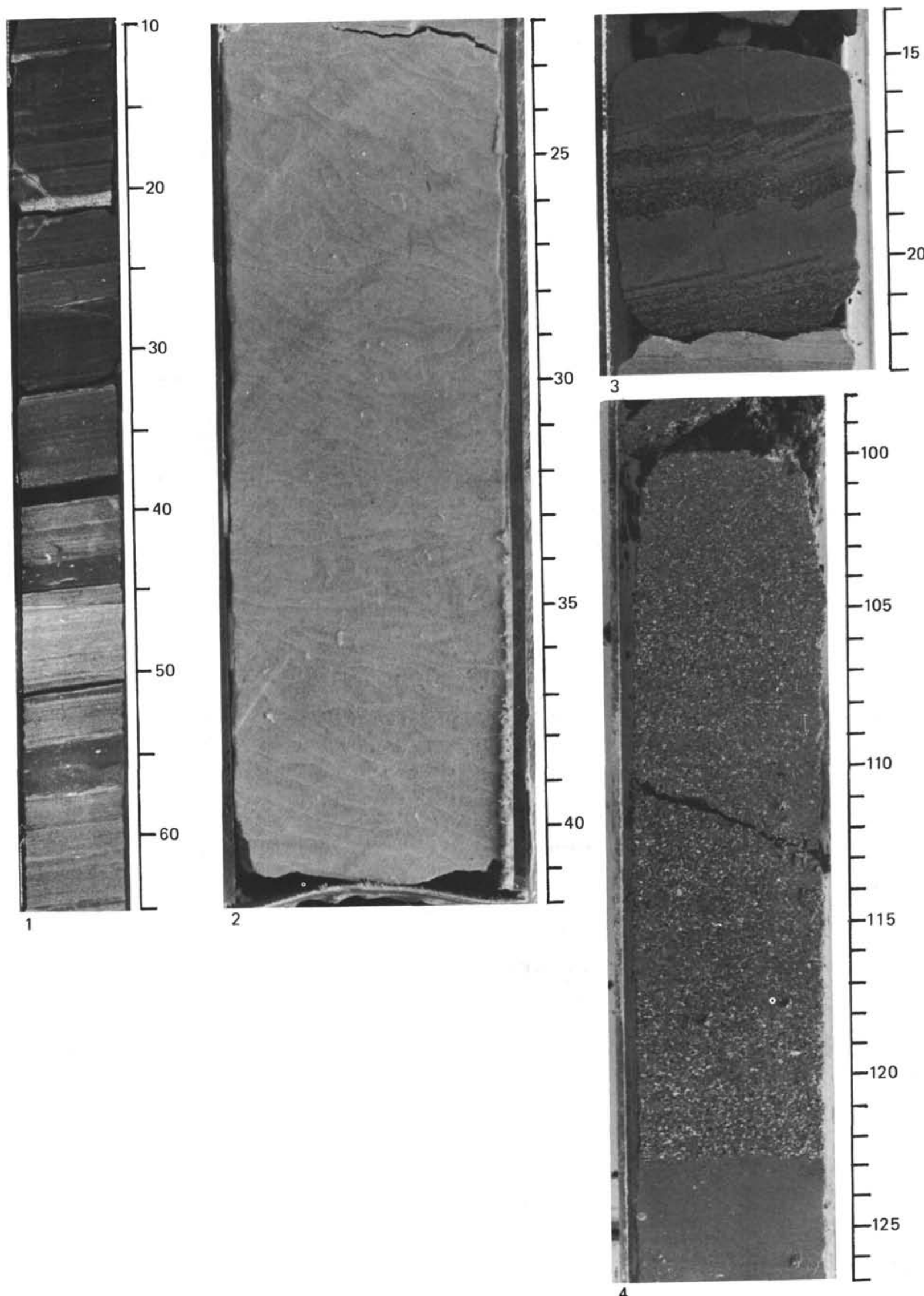


\section{PLATE 2}

Figure 1 Resedimented sandstone facies showing complete Bouma sequence, with basal graded, stratified, sandy, pebbly conglomerate $\left(\mathrm{T}_{\mathrm{a}}, 74-89 \mathrm{~cm}\right)$, the parallel-laminated interval $\left(\mathrm{T}_{\mathrm{b}}, 59-74 \mathrm{~cm}\right)$, the convolute-laminated and micro-cross-laminated interval $\left(\mathrm{T}_{c}, 48-59 \mathrm{~cm}\right)$, and the siltstone-mudstone interval $\left(\mathrm{T}_{\mathrm{d}}, 39-48 \mathrm{~cm}\right)$, capped by pelagic clay $(35-39 \mathrm{~cm}) .445-71-1,35-90 \mathrm{~cm}$.

Figure 2 Resedimented sandstone facies, showing thin, graded beds and interbedded resedimented mudstone facies with parallel lamination. 445-74-1, $65-118 \mathrm{~cm}$.

Figure 3 Resedimented conglomerate facies, showing disorganized conglomerate with opposite-dipping, imbricated clasts of Nummulites boninensis (at 66 $\mathrm{cm})$ and imbricated clasts of volcanic rock fragments. 445-74-3, 47-74 cm.

Figure 4 Resedimented conglomerate facies, showing disorganized conglomerate fabric. Clasts consist of Nummulites boninensis, andesitic and basaltic rock fragments, and limestone clasts. 445-69-2, $41-67 \mathrm{~cm}$. 
PLATE 2
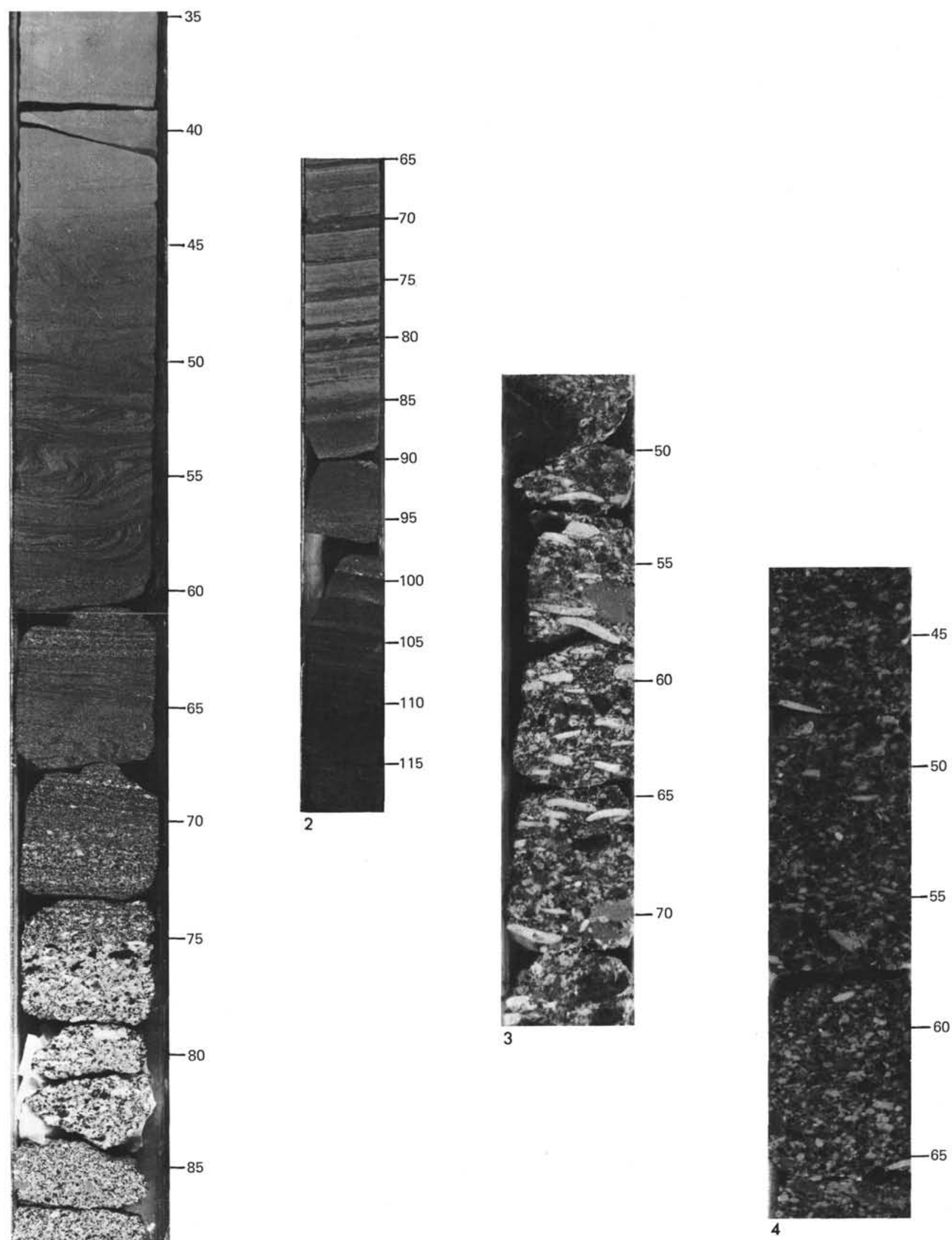


\section{PLATE 3}

Figure 1 Complete Bouma sequence in resedimented sandstone facies, showing basal graded, pebbly sand $\left(T_{a}\right)$ from 144 to $149 \mathrm{~cm}$, parallel-bedded, graded, stratified conglomerate and sand $\left(\mathrm{T}_{\mathrm{b}}\right)$ from 134 to $144 \mathrm{~cm}$; parallel-laminated sandstone $\left(\mathrm{T}_{\mathrm{b}}\right)$ at 132 to $133 \mathrm{~cm}$; micro-cross-laminated interval $\left(\mathrm{T}_{\mathrm{c}}\right)$ from 127 to $132 \mathrm{~cm}$; interbedded siltstone-mudstone interval $\left(\mathrm{T}_{\mathrm{d}}\right)$ from 199 to $127 \mathrm{~cm}$; and pelagic-clay interval $\left(\mathrm{T}_{\mathrm{e}}\right)$ from 114 to $119 \mathrm{~cm}$. 446-37-1, 110-149 cm.

Figure 2 Resedimented carbonate facies, showing limestone with undisturbed bioturbation (upper half) and disturbed bioturbation in lower half. The lower half is interpreted to represent laminar-flow zone of a debris flow, whereas the upper half is interpreted to represent a rigid plug of the same debris flow. 445-52-2, 120-148 cm.

-Figure 3 Resedimented carbonate facies, showing microfaults. $445-51-4,7-25 \mathrm{~cm}$.

Figure $4 \quad$ Resedimented carbonate facies, showing slump folding. $445-51-3,22-48 \mathrm{~cm}$. 

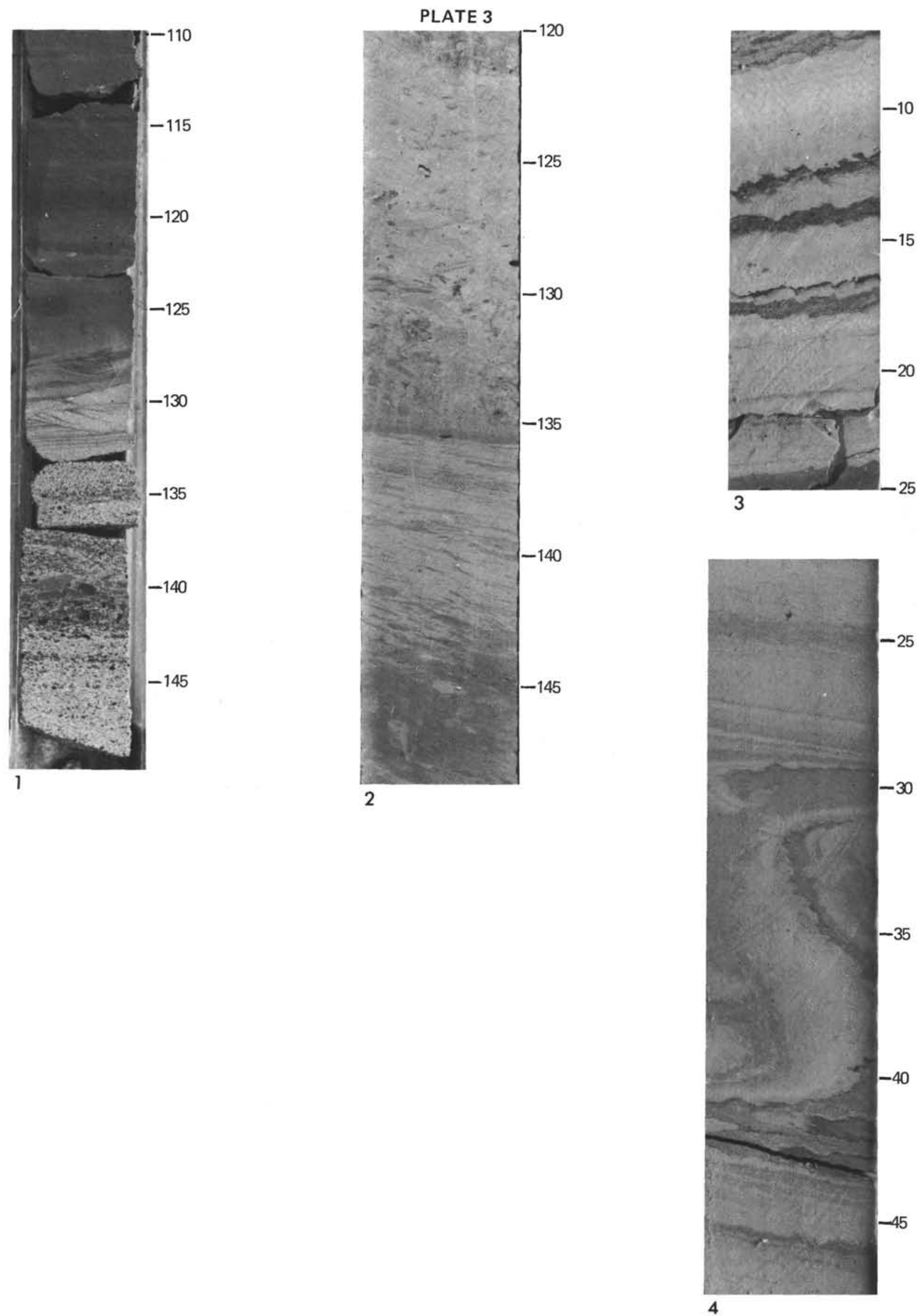


\section{PLATE 4}

Figure 1 Resedimented carbonate facies, showing slump blocks. $445-38-4,66-88 \mathrm{~cm}$.

Figure 2 Resedimented carbonate facies, showing partial Bouma sequence disrupted by slump fractures. Bouma intervals include parallel-laminated interval $\left(\mathrm{T}_{\mathrm{b}}, 94-103 \mathrm{~cm}\right)$, interbedded silt-sized and clay-sized carbonate parallel laminae $\left(T_{d}, 85-94\right.$ $\mathrm{cm})$, and pelagic interval $\left(\mathrm{T}_{\mathrm{e}}, 62-85 \mathrm{~cm}\right) .445-36-4$, $62-104 \mathrm{~cm}$.

Figure 3 Resedimented carbonate facies, showing partial Bouma sequence with graded, sandy carbonate and volcaniclastic interval $\left(\mathrm{T}_{\mathrm{a}}, 25-26 \mathrm{~cm}\right)$, parallel-laminated interval $\left(\mathrm{T}_{\mathrm{b}}, 4-25 \mathrm{~cm}\right)$, and pelagic interval $\left(\mathrm{T}_{\mathrm{e}}, 0-4 \mathrm{~cm}\right) .445-38-4,0-28 \mathrm{~cm}$. 


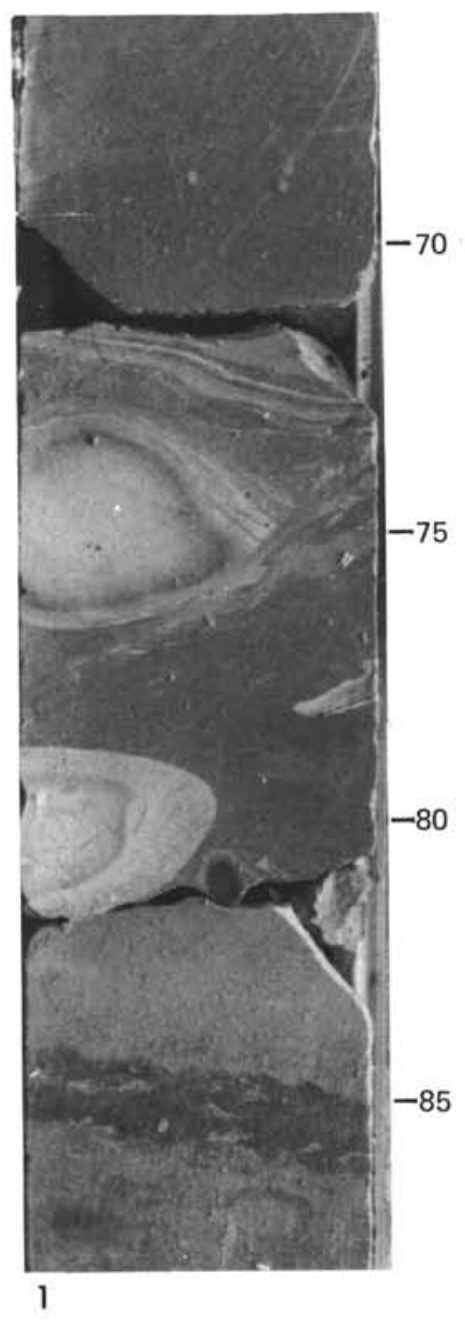

PLATE 4

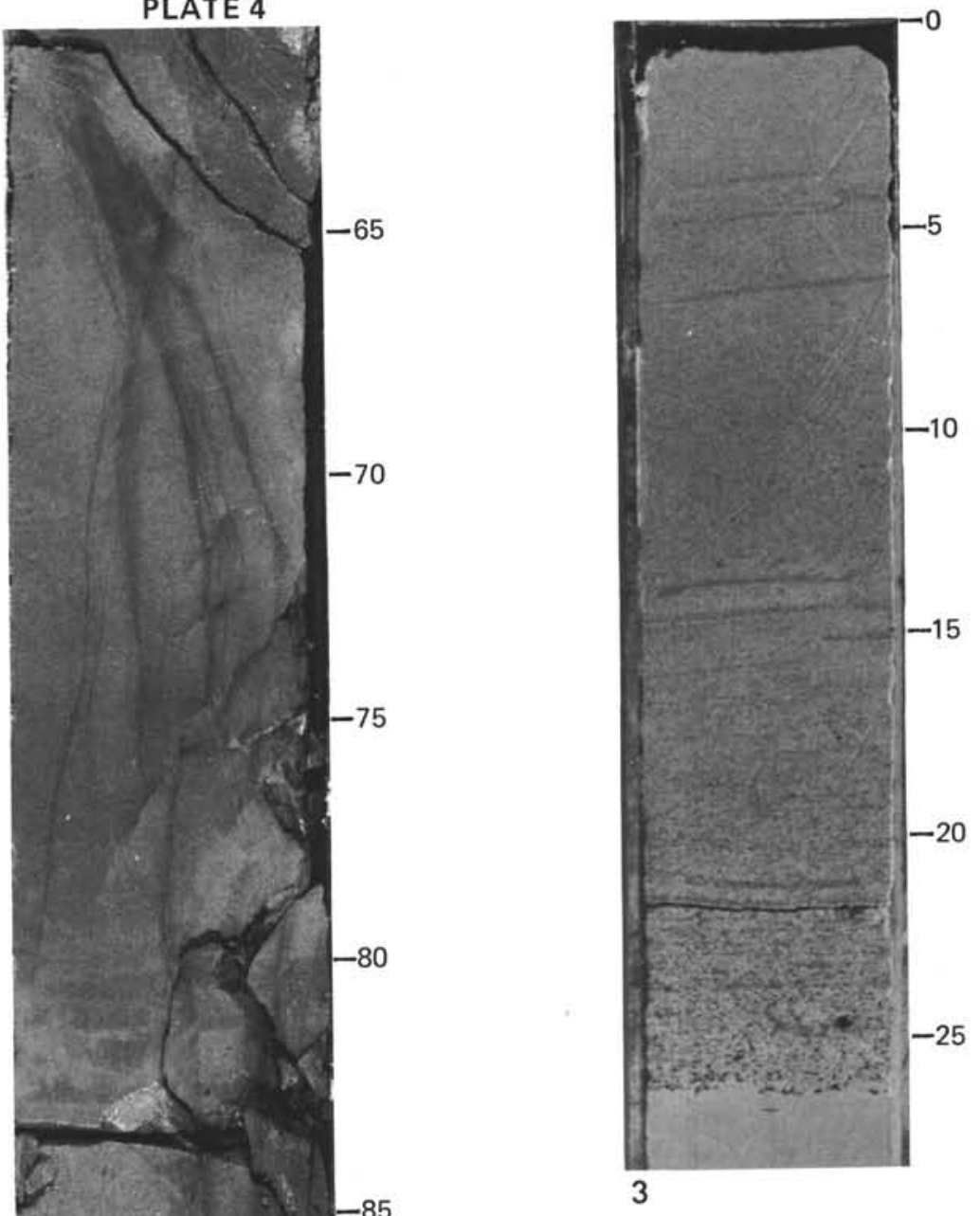




\section{PLATE 5}

Resedimented carbonate facies. $A$ shows basal parallel-laminated interval overlain by diffuse-laminated zone. $B$ shows X-ray radiograph of $A$; diffuse-laminated zone consists of micro-cross-laminated lenses of coarse-grained. foraminifer-rich carbonate. 445-58-2, $43-100 \mathrm{~cm}$. 
PLATE 5

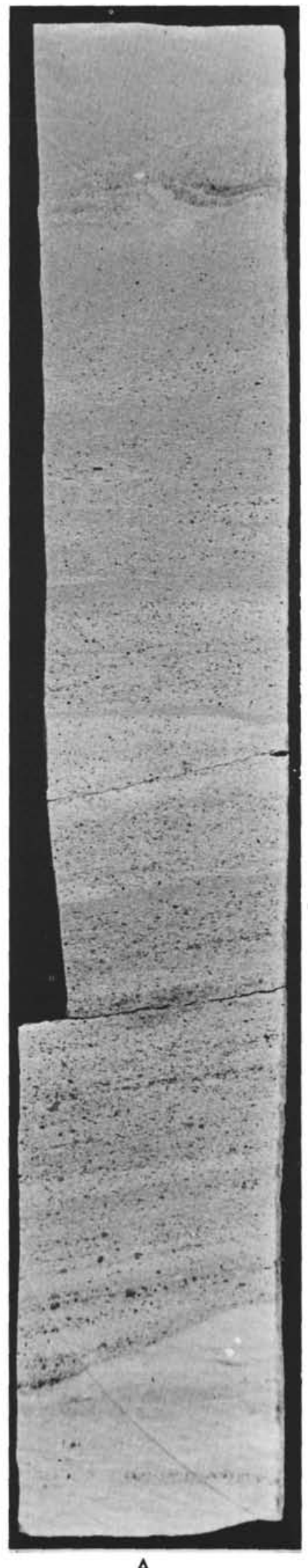

A

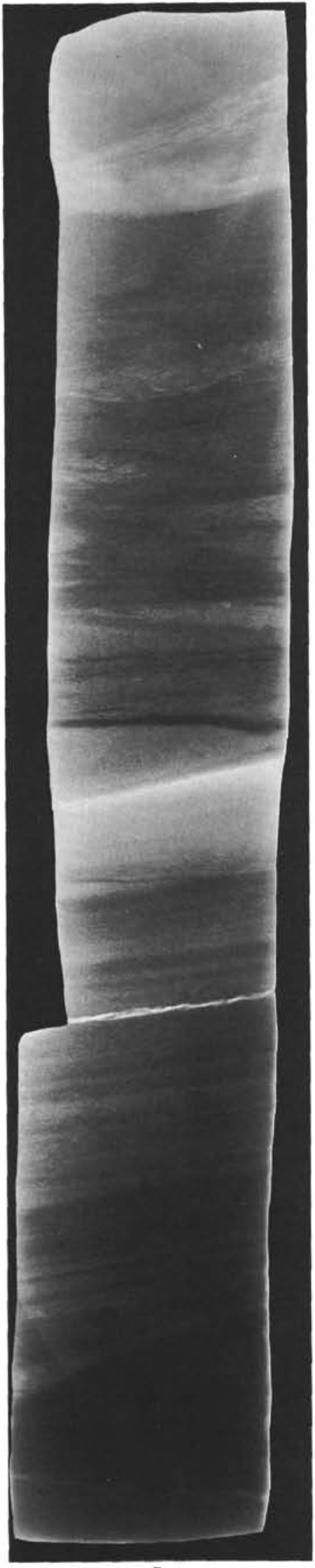

B 


\section{PLATE 6}

Resedimented carbonate facies, showing partial Bouma sequence with micro-cross-laminae and oversteepened convolute bedding $\left(\mathrm{T}_{\mathrm{c}}\right)$, overlain by silty and clayey limestone $\left(\mathrm{T}_{\mathrm{d}}\right) . A$ : core slab. $B$ : $\mathrm{X}$-ray radiograph. $445-41-1,7-31 \mathrm{~cm}$. 
PLATE 6
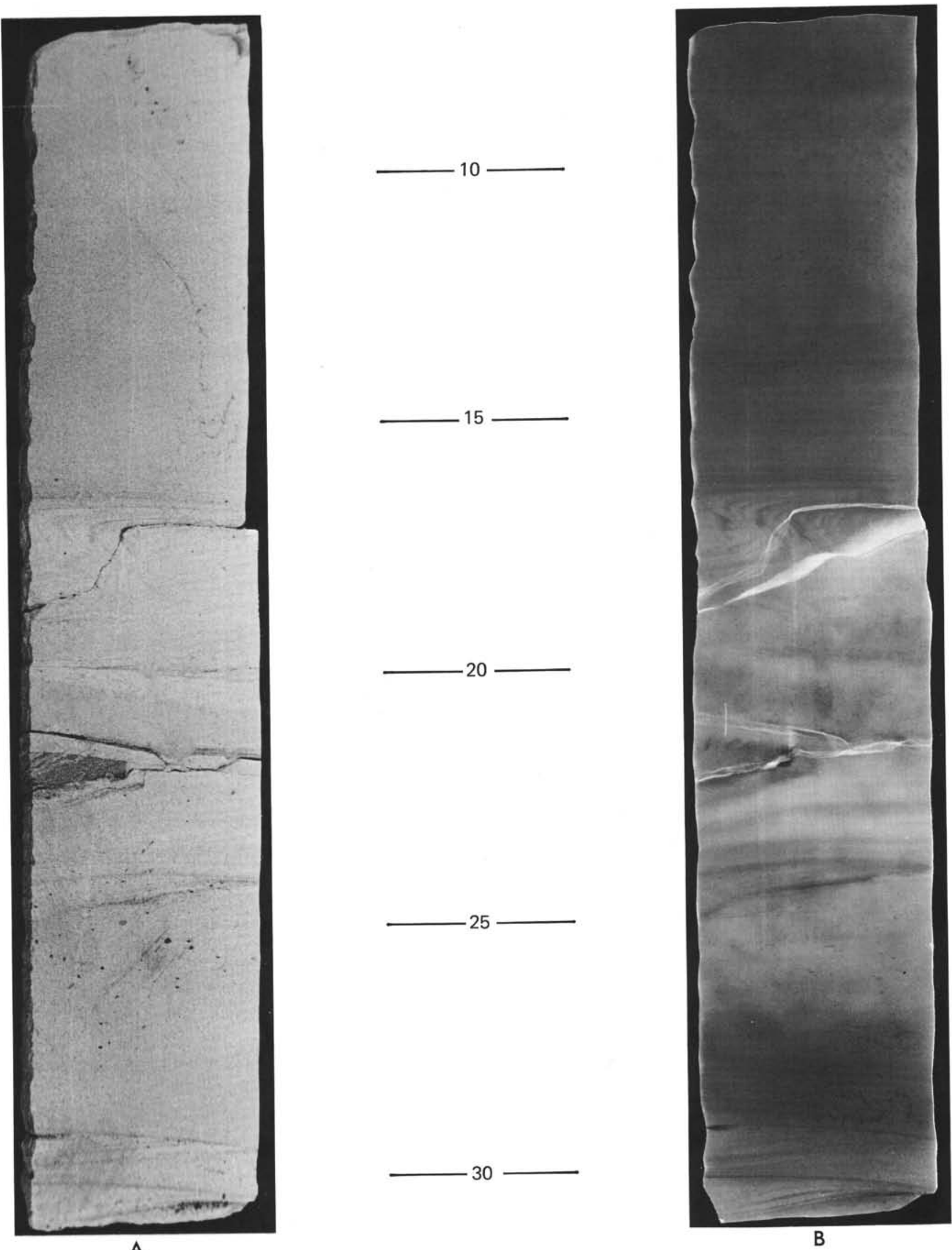